\title{
OFFICIOUS INTERMEDDLERS OR CITIZEN EXPERTS? PETITIONS AND PUBLIC PRODUCTION OF INFORMATION IN ENVIRONMENTAL LAW
}

\author{
Eric Biber*
}

\author{
Berry Brosi**
}

\begin{abstract}
Commentators have bemoaned the role that petitions and citizen suits play in driving the regulatory agendas of environmental agencies. The argument is that these forms of public participation too frequently distract agencies from the priorities that experts believe should be the focus of regulatory efforts. Using data from the listing of species protected under the U.S. Endangered Species Act, we examine whether petitions and citizen suits result in suboptimal agenda-setting by agencies. We find that petitions and litigation result in the identification of species that are at least as deserving of protection under the Act as species identified by the agency on its oun. Our results raise the possibility that public participation, by collecting diffuse information about environmental conditions, might help improve the performance of environmental agencies.
\end{abstract}

INTRODUCTION

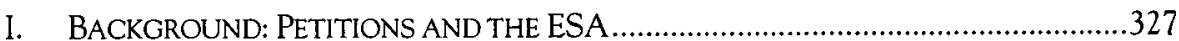

A. Petitions: A Contested Tool for Setting Agency Agendas............................327

B. An Overview of the ESA: A Controversial Tool for Protecting Biodiversity

* Assistant Professor, University of California, Berkeley, School of Law (Boalt Hall).

** Assistant Professor, Emory University, Department of Environmental Studies. Thanks to KT Albiston, Michelle Wilde Anderson, Ken Bamberger, Alejandro Camacho, Robin Kundis Craig, Holly Doremus, David Freeman Engstrom, Dan Esty, Dan Farber, David Gamage, Dale Goble, Daniel Ho, John Leshy, Albert Lin, Justin McCrary, Cal Morrill, Erin Murphy, Anne Joseph O'Connell, Dave Owen, JB Ruhl, Jim Salzman, Joe Sax, David Sklansky, Matthew Stephenson, Talha Syed, Molly Van Houweling, Frank Zimring, and participants at the UC Berkeley Center for Study of Law and Society workshop series, the Public Law and Political Economy Conference at Stanford Law School, and the Yale-Stanford Junior Faculty Forum at Yale Law School for comments. Any errors remain our own. Special thanks to Sara Clark, Heather Haney, and Mark Kirkland for assistance in compiling data for this project, and to Su Li for assistance with some of our statistical analysis. Thanks to Noah Greenwald for sharing data and providing comments. Thanks also to lan Fein and to Michael Avila and Edna Lewis in the UC Berkeley Law Library for their research assistance. This project was possible because of generous support from a grant from the UC Berkeley Faculty Committee on Research. 
C. Using the ESA Data to Answer Questions About Petitions .........................335

1. Agency Expertise in Identifying Species at Risk ...................................338

2. Public Participation and Agency Tunnel Vision .....................................340

a. The Tunnel Vision Theory in the Scholarly Literature ...................340

b. Using the Recovery Priority Data to Explore

the Tunnel Vision Theory ...........................................................342

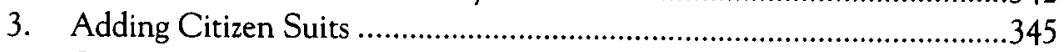

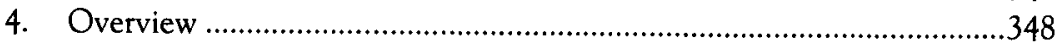

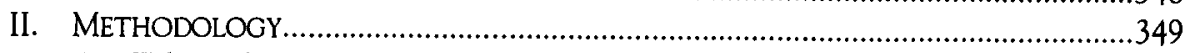

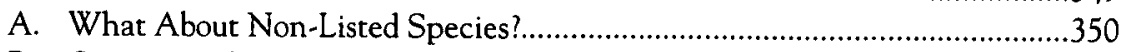

B. Overview of Our Analysis of Listed Species ................................................353

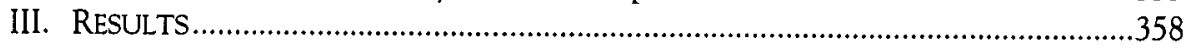

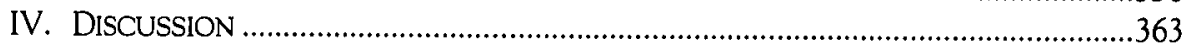

A. Why No (Relative) Agency Expertise? The Role of Dispersed Knowledge .....

1. The Role of Petitions and Citizen Suits in Bringing Dispersed Information to the Agency's Attention ................................................365

2. Drawing on a Diverse Range of Public Participants to Maximize Information Production ....................................................368

3. Are Petitions and Citizen Suits Worth It? ...........................................370

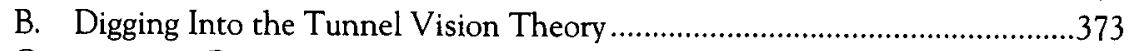

V. CONCLUSION: BROADER IMPLICATIONS FOR ENVIRONMENTAL

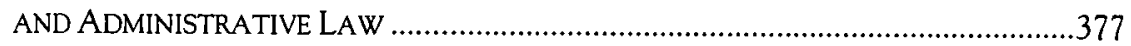

A. Identifying Other Areas Where Petitions Might Improve

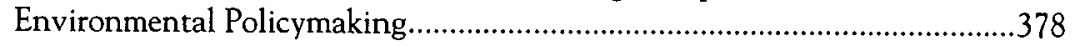

B. Reconsidering Judicial and Scholarly Attitudes Towards Petitions and Citizen Suits in Environmental Law and More Broadly .........................382

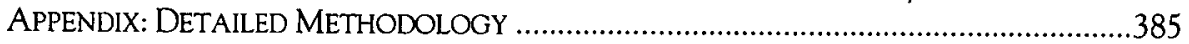

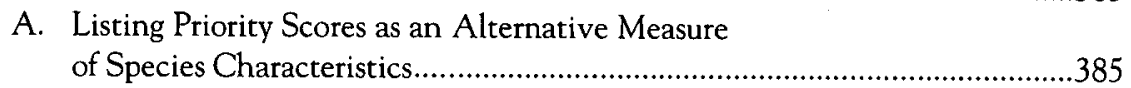

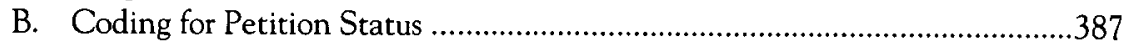

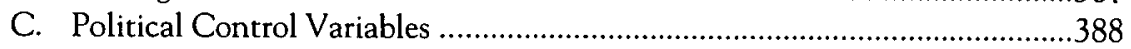

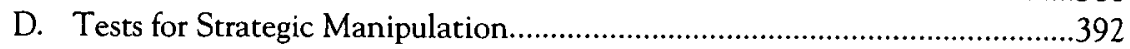

E. Time Delay Between the Date of Petition/Litigation and Date of Assignment of Recovery Priority Score....................................394

F. Description of Statistical Analysis and Diagnostic Tests..............................395

\section{INTRODUCTION}

The U.S. Environmental Protection Agency (EPA) has begun what can fairly be described as the most ambitious regulatory effort in the history of American environmental law: regulating the emissions of carbon dioxide, or in other words, almost everything associated with a modern industrial economy. 
EPA's first steps toward that goal have prompted at least sixteen lawsuits and congressional efforts to terminate EPA's regulatory efforts.'

EPA's work was not initiated by congressional pressure, nor by a court order, nor even by a response to international pressure or United Nations reports-although all of these, and particularly the Supreme Court's decision in Massachusetts v. EPA, ${ }^{2}$ may have played a role once the process began. Instead, the administrative process was initiated by a petition from nongovernmental groups. While the Supreme Court's decision and ensuing battles have been in the spotlight, the petition that began the whole process has been relatively ignored.

EPA's efforts to regulate carbon dioxide are only the most significant example of the use of petitions to affect agency regulatory agendas. The carbon dioxide petition was filed pursuant to a generic provision of the Administrative Procedure Act (APA) that allows any "interested party" to file a petition seeking the enactment, revision, or repeal of an agency rule. ${ }^{4}$ Congress has supplemented the APA's petition provision in a series of environmental statutes, such as the U.S. Endangered Species Act (ESA), that impose more stringent requirements for agencies to receive and respond to petitions within specific timeframes. ${ }^{5}$

Petitions can be a powerful tool for citizens, businesses, or interest groups seeking to influence the administrative process. A petition can force an agency to consider a topic that it has ignored-whether from a lack of resources, a lack of political will, or a lack of information. Agencies can of course try to ignore the petition, but they face the possibility of judicial review. ${ }^{6}$ As with the carbon dioxide example, petitions can have tremendous consequences.

Yet the little scholarly commentary on petitions has been strongly negative, focused on the idea that petitions divert agencies from pursuing the most serious problems that deserve regulatory attention. Indeed, an overly generous petition process is blamed for the near demise of the Consumer

1. See Holly Doremus, Lining up for Endangerment Litigation, LEGAL PLANET (Feb. 20, 2010), htt://legalplanet.wordpress.com/2010/02/20/lining-up-for-endangerment-litigation; Dan Farber, "Murky" Resolution Vote, LEGAL PLANET (June 10, 2010), http://legalplanet.wordpress.com/2010/06/10/murkyresolution-vote.

2. 549 U.S. 497 (2007).

3. Id. at 510 .

4. 5 U.S.C. $\$ 553($ e) (2006). See, e.g., O'Keefe's, Inc. v. U.S. Consumer Prod. Safety Comm'n, 92 F.3d 940 (9th Cir. 1996) (affirming agency denial of petition); Motion Picture Ass'n of Am., Inc. v. Oman, 969 F.2d 1154, 1157 (D.C. Cir. 1992) (noting petition by plaintiff for change to agency rule); Seeley v. Dep't of Transp., No. 91-70145, 1992 WL 124442 (9th Cir. June 9, 1992) (affirming agency denial of petition); Her Majesty the Queen in Right of Ont. v. EPA, 912 F.2d 1525 (D.C. Cir. 1990) (same).

5. See infra notes $21-24,41$ and accompanying text.

6. Massachusetts v. EPA, 549 U.S. at 527-28. 
Product Safety Commission (CPSC) in the 1970s. ' Similarly, environmentalist petitions under the ESA have been criticized for focusing on species that are charismatic or serve to obstruct development, rather than on species that most need protection. ${ }^{8}$

These critiques of petitions are part of a more sweeping challenge to all forms of public participation in environmental law, including the citizen suit provisions-a common feature of environmental statutes-that allow broad opportunities to challenge agency decisions in court.' According to the critiques, overly broad public participation can lead to irrational regulation that is inconsistent with an expert assessment of what regulatory priorities should be.

Other than a few qualitative case studies of the CPSC from the early 1980s, however, these sweeping critiques have been made without attempting to empirically evaluate the extent to which petitions for rulemaking do, in fact, affect agency decisionmaking, perhaps because of a lack of relevant data. ${ }^{10}$ There is a similar lack of empirical research on citizen suits, also perhaps due to the lack of relevant data. In this Article, we take advantage of data from the U.S. Fish and Wildlife Service (FWS), one of the two lead agencies in charge of implementing the ESA, to examine how both petitions and citizen suits affect environmental decisionmaking, and how broadly the lessons from the CPSC context can be applied.

With this data, we compare species that are identified for listing through the petition process with species that are identified for listing by the agency on its own. We use that comparison to explore a series of questions: Are species listed as a result of petitions at a higher risk of extinction than other listed species? Do they cost more to restore to healthy population levels? Are they more likely to conflict with development projects being pursued by other federal agencies, such as dams or roads? Our data also lets us answer the same questions with regard to species that were listed after having been the subject of litigation, as compared to species that were not the subject of litigation prior to listing.

Contrary to the criticisms in the literature, we find no statistically significant differences on any of these factors between species listed as a result of

7. See infra notes $30-40$ and accompanying text.

8. See infra notes $71-73$ and accompanying text.

9. See supra notes $21-24$.

10. There is one qualitative study that attempts to examine the extent to which different actorsCongress, the president, interest groups through petitions, the courts, etc.-affect the serting of rulemaking agendas by agencies. Marissa M. Golden, Who Controls the Bureaucracy? The Case of Agenda Setting, 2003 NAT'L PUB. MGMT. RES. CONF. 1, 12, 15 (finding that for some agencies, petitions for rulemaking do have a significant impact on rulemaking agendas). However, that project does not attempt to analyze the nature of the impact of petitions on agency decisions. 
petitions and species listed on the agency's own initiative. If anything, petitions seem to better identify at-risk species that cost relatively little to restore to health. We find similar results for species that were the subject of litigation under the ESA's citizen suit provision.

Our results pose a powerful challenge to the criticisms of petitions as debilitating to agencies, and to the broader narrative that public participation (and citizen suits in particular) undermines the use of technical expertise in environmental law. In fact, our results suggest that petitions and litigation may even help the agency better achieve one of its core statutory goals: identifying species that warrant protection under the ESA.

The classic argument for citizen participation in environmental law is the need to resist agency capture by regulated parties. While this argument may be valid (we cannot answer it definitively here), what is remarkable about both petitions and citizen suits under the ESA is that they are able to achieve results that are, from a "technical perspective" (as measured by the ability to identify species at risk), as good as or better than those of the agency acting alone.

This outcome highlights a very different rationale for citizen participation-namely, its ability to gather diffuse information about environmental problems to help an agency achieve its goals. Information that is dispersed in space or time is a common characteristic of environmental harms, and it may be very difficult for a single party (such as an administrative agency) to fully collect that information. Our results indicate that such information may be amenable to collection and reporting by the public as a whole using tools such as petitions.

This role for public participation in environmental law has strong similarities with what Yochai Benkler has called "peer production," in which the internet allows large numbers of individuals to contribute to the production of information. ${ }^{11}$ Peer production has been the inspiration for a series of reforms to improve government regulation, such as proposals for "peer to patent" (public peer review of patent applications) ${ }^{12}$ and the revamping of environmental regulation. ${ }^{13}$ All of these efforts have been premised on the use of the internet to reduce the costs of gathering, processing, and distributing information, and

11. See YOCHAI BENKLER, THE WEALTH OF NETWORKS (2006); Yochai Benkler, Coase's Penguin, or, Linux and The Nature of the Firm, 112 YALE L.J. 369 (2002).

12. See Beth Simone Noveck, "Peer to Patent": Collective Intelligence, Open Review, and Patent Reform, 20 HARV. J.L. \& TECH. 123 (2006).

13. See Beth S. Noveck \& David R. Johnson, A Complex(ity) Strategy for Breaking the Logjam, 17 N.Y.U. ENVTL. L.J. 170, 187-92 (2008). 
all are relatively untested..$^{14}$ In what is often called "Government 2.0," the Obama Administration has taken steps to harness public participation in similar ways using the internet. ${ }^{15}$ Our analysis of ESA listing petitions and litigation provides evidence that the public can collect diffuse information to help government regulation even without the internet.

While there are limits to the conclusions we can draw from a study of one particular statutory scheme, ${ }^{16}$ listing decisions under the ESA have relevance for much of environmental law. ESA listing decisions apply technical expertise to decide individual cases based on a specific set of factors, a characteristic shared by many other environmental statutes. ${ }^{17}$ Thus, our results provide reason to more generally embrace petitions and citizen participation in environmental law. Contrary to the leitmotif in the environmental law literature that we must necessarily choose between openness to the public and expert decisionmaking, we find that increasing public participation need not carry a cost in terms of technical expertise. Indeed, public participation may even improve technical decisionmaking, especially when information is diffuse. Thus, engineers, economists, and biologists alike might have reason to celebrate greater public engagement in environmental law.

In Part I, we outline the petition for rulemaking process both in general and specifically in environmental law, and survey the scholarly critiques of the petition process. We also provide some legal background on the role petitions play in the ESA and explain how the ESA data helped us to develop and test our hypotheses. In Part 0 , we explain the outlines of our methodology (leaving the details to the Appendix). In Part III, we present the results of our analysis, and in Parts IV and V we discuss their implications.

14. See Noveck, supra note 12, at 128-29, 143 (noting how technology makes public peer review of patent applications possible, and noting that this is a pilot program); Noveck $\&$ Johnson, supra note 13, at 170 (describing how EPA could "use technology to improve the agency's" environmental decisionmaking, principally through improving notice and comment rulemaking procedures).

15. See Presidential Memorandum on Transparency and Open Government, 74 Fed Reg. 4685 (Jan. 26, 2009), available at http://www.whitehouse.gov/the_press_office/Transparency_and_Open_ Government (posting an Executive Order calling for agencies to develop tools to better harness public participation in government decisionmaking).

16. For instance, as we discuss in Part V.A, the Endangered Species Act (ESA) structures listing decisions in a way that may make them particularly suited to the petition process. Likewise, we are limited in our ability to observe how the Fish and Wildlife Service (FWS) might have listed species in the absence of litigation or petitions.

17. See infra notes 209-211 and accompanying text. 


\section{BACKGROUND: PETITIONS AND THE ESA}

\section{A. Petitions: A Contested Tool for Setting Agency Agendas}

The APA contains a generic provision that (unless trumped by a more specific substantive statute) requires all agencies to receive petitions for rulemaking. ${ }^{18}$ The APA also imposes a duty on agencies to respond to those petitions within a reasonable time. ${ }^{19}$ A study from the mid-1980s found that administrative agencies in general were receiving hundreds of petitions for rulemaking each year, with the Food and Drug Administration and EPA topping the list (each with over two hundred petitions received per year). ${ }^{20}$

Particularly in the 1970s, Congress was not satisfied with the generic APA provisions. It enacted sweeping petition provisions in a wide range of statutes, with a particular focus on environmental laws, such as the ESA, ${ }^{21}$ the Resource Conservation and Recovery Act (governing hazardous wastes), ${ }^{22}$ the Toxic Substances Control Act (governing the production of toxic chemicals), ${ }^{23}$

18. See 5 U.S.C. $\$ 553(\mathrm{e})$ (2006) ("Each agency shall give an interested person the right to petition for the issuance, amendment, or repeal of a rule.").

19. One provision of the APA requires agencies to provide reasons for any denial of a petition. See id. $\$ 555(\mathrm{e})$.

Prompt notice shall be given of the denial in whole or in part of a written application, petition,

or other request of an interested person made in connection with any agency proceeding.

Except in affirming a prior denial or when the denial is self-explanatory, the notice shall be accompanied by a brief statement of the grounds for denial.

Id. While this provision is theoretically limited to petitions "made in connection with [an] agency proceeding," the courts have not read it that way. See William V. Luneburg, Petitioning Federal Agencies for Rulemaking: An Overview of Administrative and Judicial Practice and Some Recommendations for Improvement, 1988 WIS. L. REV. 1, 9-10 nn.42-43; see also, e.g., Auer v. Robbins, 519 U.S. 452, 459 (1997) (requiring a statement of reason for denial under 5 U.S.C. $\$ 555(\mathrm{e})$ for a claim brought under the Fair Labor Standards Act of 1938); Nat'l Wrestling Coaches Ass'n v. Dep't of Educ., 366 F.3d 930, 948 (D.C. Cir. 2004) (noting that the provisions of 5 U.S.C. $\$ 555(\mathrm{e})$ may be used for Title IX claims brought against the Department of Education).

Separate provisions of the APA require agencies to complete matters presented to them within a "reasonable time," 5 U.S.C. $\$ 555$ (b), and grant courts the authority to compel agency action "unreasonably delayed." Id. $\$ 706(1)$. Together, these provisions impose on agencies a dury to respond in a timely manner to petitions. See In re Am. Rivers \& Idaho Rivers United, 372 F.3d 413, 418-19 (D.C. Cir. 2004) (finding that an agency is "obligated under the APA to respond" to petitions under $\S 555$ (b) and a court may enforce this duty pursuant to $\S 706(1))$; Estate of French v. Fed. Energy Regulatory Comm'n, 603 F.2d 1158, 1167 (5th Cir. 1979) (same); Luneburg, supra, at 9-10 nn.4244 (noting the applicability of 5 U.S.C. $\S 555(\mathrm{~b})$ ).

20. See William V. Luneburg, Petitions for Rulemaking: Federal Agency Practice and Recommendations for Improvement, 1986 ADMIN. CONF. U.S. REP. 493, 519-20. Many of the petitions that EPA received were from pesticide manufacturers seeking changes to the regulations for registered pesticides. Id. at 551 .

21. 16 U.S.C. $\$ \$ 1533(\mathrm{~b})(3)(\mathrm{A})-(\mathrm{C})(2006)$.

22. 42 U.S.C. $\$ 6974(\mathrm{a})(2006)$.

23. 15 U.S.C. $\$ \$ 2601-2692(2006)$. 
and the Surface Mining Control and Reclamation Act (governing coal strip mining). ${ }^{24}$ Many of these provisions-including the ESA petition provisionimpose specific deadlines for the agency to either accept or reject the petition.

Yet, despite the prevalence of agency petition provisions at the federal level, ${ }^{25}$ they have been almost completely ignored in the legal and political science literature. ${ }^{26}$ There is an extensive legal, political science, and public administration literature on public participation in the administrative process that focuses on public participation after the agency has decided to take a particular action. ${ }^{27}$ But as one scholar recently noted, there has been little attention to the "rulemaking agendas of federal agencies" - in other words, how agencies' rulemaking agendas are set (including through tools such as petitions), who sets those agendas, and what this might imply for the quality of agency decisionmaking. ${ }^{28}$ The few studies of petitions have tended to focus

24. 30 U.S.C. $\S 1211(\mathrm{~g})(1)(2006)$.

25. Many states also have petition procedures. See Neal D. Woods, Promoting Participation? An Examination of Rulemaking Notification and Access Procedures, 69 PUB. ADMIN. REV. 518 (2009).

26. One legal scholar has surveyed agency procedures for processing and deciding petitions, summarized the total number of petitions reported by a range of agencies, and provided brief qualitative case studies of the nature of petitions received by seven federal agencies. Those studies did not analyze the impact petitions had on agency decisions. See Luneburg, supra note 20, at 519-20, 531.

27. This literature generally examines whether public notice and comment on agency rulemaking proposals influence the agency's final rule and which parties participate in the process. See, e.g., Cary Coglianese, Litigating Within Relationships: Disputes and Disturbance in the Regulatory Process, 30 LAW \& SOC'Y REV. 735 (1996) (studying notice, comment, and litigation against agency rulemaking); Mariano-Florentino Cuellar, Rethinking Regulatory Democracy, 57 ADMIN. L. REV. 411 (2005); Scott R. Furlong \& Cornelius M. Kerwin, Interest Group Participation in Rule Making: A Decade of Change, 15 J. PUB. ADMIN. RES. \& THEORY 353 (2005) (using survey data from interest groups to determine the importance of participation in administrative processes); Marissa Martino Golden, Interest Groups in the Rule-Making Process: Who Participates? Whose Voices Get Heard?, 8 J. PUB. ADMIN. RES. \& THEORY 245 (1998); David C. Nixon, Robert M. Howard \& Jeff R. DeWitt, With Friends Like These: Rule-Making Comment Submissions to the Securities and Exchange Commission, 12 J. PUB. ADMIN. RES. \& THEORY 59 (2002); Jason Webb Yackee \& Susan Webb Yackee, A Bias Towards Business? Assessing Interest Group Influence on the U.S. Bureaucracy, 68 J. POL. 128 (2006); Susan Webb Yackee, Sweet-Talking the Fourth Branch: The Influence of Interest Group Comments on Federal Agency Rulemaking, 16 J. PUB. ADMIN. RES. $\&$ THEORY 103 (2005).

Most of these articles conclude that interest groups dominate the petition process, with mixed impacts on the ultimate substance of rules. See, e.g., Coglianese, supra, at 735; Golden, supra, at 245; Nixon et al., supra, at 59; Yackee \& Yackee, supra, at 128; Yackee, supra, at 103; see also William West, Admimistrative Rulemaking: An Old and Emerging Literature, 65 PUB. ADMIN. REV. 655, 662 (2005) (noting scholarly consensus that organized groups dominate notice and comment and that agencies "change proposed rules fairly often in ways that are consistent with some of those comments"). But see Cuellar, supra, at 468-72 (finding wide participation by the public in a number of rulemaking proceedings).

28. See Golden, supra note 10, at 3-4; see also West, supra note 27, at 663 (noting that scholars have paid "little attention" to how outside actors shape agency agendas). 
on who most uses the process and which agencies tend to receive the most petitions, and they have found that industry is the dominant petitioner. ${ }^{29}$

The only efforts to examine whether and how petitions affect the substance of agency decisionmaking have been two qualitative case studies of the Consumer Product Safety Commission (CPSC) published in the early 1980s. The CPSC was created in the early 1970s in response to concerns about defective or hazardous products. ${ }^{30}$ At the time, citizen participation provisions such as petitions were seen as a tool to prevent agency capture by regulated interests and to prevent delay in regulating serious harms. ${ }^{31}$ Accordingly, the CPSC's enabling act included extremely powerful petition provisions intended to make the agency as responsive as possible to public concerns over potentially unsafe products. ${ }^{32}$ The agency was given 120 days to grant or deny a petition, and if the agency denied a petition or failed to meet the deadline, a court could consider the petition de novo, with the burden on the petitioner to prove that the product posed an unreasonable risk of injury. ${ }^{33}$

The CPSC was subject to significant criticism from consumer groups (for being too slow to regulate) and from business (for being unreasonable in its regulation), and in the early 1980s its political status had sunk low enough that Congress substantially restricted its authority, increased the procedural hurdles for regulation, and eliminated the tight petition deadlines. ${ }^{34}$

29. One study of the Surface Mining Control and Reclamation Act found that most petitions were filed by industry, while environmental groups or individual citizens tended not to be involved until the permitting or enforcement stage. See Uday Desai, Public Participation in Environmental Policy Implementation: Case of the Surface Mining Control and Reclamation Act, 19 AM. REV. PUB. ADMIN. 49 (1989). A more recent work-in-progress has tentatively found that petitions are an important factor in setting agency rulemaking agendas for at least some agencies—in particular, the Federal Communications Commission and the National Highway Traffic Safety Administration-while other agencies such as the SEC have little petition activity, with industry again dominating. See Golden, supra note 10, at 9-19. For the only environmental agency studied (EPA), Golden found that the agenda was dominated by statutory deadlines and consent decrees triggered by litigation enforcing those deadlines. Id. at 9 .

30. See Richard A. Merrill, CPSC Regulation of Cancer Risks in Consumer Products: 1972-1981, 67 VA. L. REV. 1261, 1263-64 (1981); Teresa M. Schwart2, The Consumer Product Safety Commission: A Flawed Product of the Consumer Decade, 51 GEO. WASH. L. REV. 32, 42-45 (1982).

31. See, e.g., Roger C. Cramton, The Why, Where and How of Broadened Public Participation in the Administrative Process, 60 GEO. L.J. 525, 527-30 (1972); Comment, Public Participation in Federal Administrative Proceedings, 120 U. PA. L. REV. 702, 707-34 (1972).

32. See Antonin Scalia \& Frank Goodman, Procedural Aspects of the Consumer Product Safety Act, 20 UCLA L. REV. 899, 899-900 (1973); Schwartz, supra note 30, at 45 n.87 (noting the legislative history of the Act in which the petition provision was to "help assure that the CPSC did not succumb to 'bureaucratic inertia"').

33. See Schwartz, supra note 30, at 45-46.

34. See Merrill, supra note 30, at 1373-75; Schwartz, supra note 30, at 55. Interference with the agency's ability to set its own priorities was a key reason for the repeal of the petition provision. See JERRY L. MASHAW, DUE PROCESS IN THE ADMINISTRATIVE STATE 262-63 (1985); WILliam F. 
Two legal scholars reviewed the history of the CPSC's regulatory efforts during the 1970s and harshly criticized the petition process for contributing to the agency's dysfunction. They argued that the petition process significantly diverted the agency from any systematic prioritization among the wide range of potentially dangerous or hazardous products it could have regulated. According to the authors, the haphazard process by which the CPSC developed its regulatory agenda in its formative early years-driven in large part by petitions-led it to choose projects that were perceived as unsuccessful and unimpressive, ultimately costing it tremendous political capital. ${ }^{36}$ They concluded that petitions in general were problematic:

As a general rule it is unwise to give petitioners such power to influence an agency's direction. Often petitioners promote narrow concerns; indeed, many seek regulatory actions out of economic self-interest. They often have limited information on which to base their claims and cannot appreciate the relative importance of their requests.... [I]nvesting petitioners with legal rights to press their particular interests does not assure, and indeed may thwart, the agency's fulfillment of its obligation to attend overall to matters of public importance. The agency is responsible for setting its priorities; if it fails to do so, Congress through legislation and oversight, not petitioners, should provide it with necessary direction. ${ }^{37}$

This quote highlights the potential for private parties-especially industry, but also environmental groups-to utilize the petition process to distort and distract the agency from what "should" be its higher priority goals for regulation. ${ }^{38}$

WEST, CONTROLLING THE BUREAUCRACY: INSTITUTIONAL CONSTRAINTS IN THEORY AND PRACTICE $43(1995)$.

35. See Merrill, supra note 30 , at 1274 (stating that the petition process has put the agency in a "reactive posture by making the agency's regulatory agenda dependent on demands for action by outside groups"); id. at 1363 (stating that the attention to petitions "distort[ed the agency's] judgments about how [it] should allocate its limited resources"); Schwartz, supra note 30, at 49-52 (describing the "fiasco" of pool slide regulations that were prompted by a petition).

Equally harsh is the assessment of Jerry Mashaw, who said that a "reasonable description of CPSC regulation" under the petition process was a "disaster." MASHAW, supra note 34, at 262. Mashaw raised the same concerns that Schwartz and Merrill did: "Petitions for rules have swamped the agency in unproductive investigation of useless subjects and destroyed its capacity to set a reasonable agenda for regulation." Id. at 262-63.

36. See Merrill, supra note 30, at 1270-71; Schwartz, supra note 30, at 47-49.

37. Schwart2, supra note 30, at 56-57; see also Merrill, supra note 30, at 1363-64 (calling for a "more skeptical approach to public petitions" in which the agency has much greater leeway to reject petitions based on inconsistency with agency priorities).

38. The "fiasco" in which the CPSC attempted to set safety standards for pool slides was initiated by a petition from a competitor. See Schwartz, supra note 30, at 49-52. The limited empirical data on who is involved in the petition process notes a high participation rate for industry. See Desai, supra note 29; see also Lars Noah, Sham Petizioning as a Threat to the Integrity of the Regulatory Process, 74 N.C. L. REV. 1 
Thus, the scholarly literature portrays a well-intentioned public participation tool-the petition-as easily manipulated to undermine the very regulatory programs that it was intended to benefit.

This is a story that appears to have some resonance with the courts as well. Judges generally resist involving the courts in setting agency regulatory agendas, such as when plaintiffs challenge agencies' failures to act. ${ }^{39}$ The judicial fear appears to be that litigation initiated by outside groups will distract agencies from the agency's own priorities. In the context of petitions, these concerns probably contribute to the significant deference that courts give to agency decisions to deny petitions for rulemaking. ${ }^{40}$

\section{B. An Overview of the ESA: A Controversial Tool for Protecting Biodiversity}

Enacted in 1973, the ESA has both an extremely broad citizen suit provision, ${ }^{41}$ and a very generous petition provision. ${ }^{42}$ These provisions were likely prompted by concerns similar to those that animated design of the CPSCagency capture and indifference to important regulatory problems. ${ }^{43}$ Indeed, there is evidence in the legislative history that the ESA citizen suit provisions

(1995) (contending that industry petitions for administrative action are widespread and often are intended to set up obstacles for competitors).

39. See Eric Biber, The Importance of Resource Allocation in Administrative Law, 60 ADMIN. L. REV. 1, 25-34 (2008); Eric Biber, Two Sides of the Same Coin: Judicial Review of Administrative Agency Action and Inaction, 26 VA. ENVTL. L.J. 461, 478-79 (2008) [hereinafter Biber, Two Sides].

40. See Massachusetts v. EPA, 549 U.S. 497, 527-28 (2007).

41. See Bennett v. Spear, 520 U.S. 154, 164-65 (1997) (finding that the ESA citizen suit provision allowing "any person" to sue to enjoin violations of the Act is "an authorization of remarkable breadth when compared with the language Congress ordinarily uses" and that the provision "expanded [standing] to the full extent permitted" under the Constitution).

42. 16 U.S.C \& 1533(b) (2006).

43. See, e.g., Endangered Species Act of 1973: Hearings on S. 1592 and S. 1983 Before the Subcomm. on Env't of the S. Comm. on Commerce, 93d Cong. 80-81 (1974) (statement of Thomas Garrett, Wildlife Director, Friends of the Earth) (noting that the citizen suit provision might allow for greater enforcement against private violations of the Act); Endangered Species: Hearings on H.R. 37, H.R. 470, H.R. 471, H.R. 1461, H.R. 1511, H.R. 2669, H.R. 2735, H.R. 3310, H.R. 3696, H.R. 3795, H.R. 4755, H.R. 2169 and H.R. 4758 Before the Subcomm. on Fisheries $\mathcal{E}$ Wildlife Conservation $\mathcal{E}$ the Env't of the H. Comm. on Merch. Marime $\mathscr{E}$ Fisheries, 93d Cong. 299, 304 (1973) [hereinafter House Endangered Species Hearings] (statement of Thomas Garrett, Wildlife Director, Friends of the Earth) (noting that there "are a lot of people interested in endangered species who live in the areas where endangered species persist who know what is going on, and who would be likely to observe some kind of infringement"); id. at 344 (statement of Rep. Eckhardt, Member, H. Comm. on Merch. Marine \& Fisheries) (noting that "sometimes the syndrome of the possum guarding the chicken coop is applicable to the administrative agencies, and maybe a little self-help will keep the representative of the public interest really representing the public interest"); H.R. REP. NO. 93-412, at 12 (1973) (noting that the petition provision is intended "to require that [the agency] provide adequate protection to any species of fish or wildlife which is or which might become endangered"). 
were modeled in part on the CPSC provisions. ${ }^{44}$ Thus, analyzing the actual performance of petition-spurred versus sua sponte agency decisionmaking under the ESA allows us to respond empirically to the critique (based on the CPSC's experiences) that public participation through petitions and citizen suits is more often distracting than helpful to an agency.

In addition, the ESA imposes significant data collection and production requirements on the implementing agencies. ${ }^{45}$ In this Article, we take advantage of the ESA's petition, citizen-suit, and data requirements to directly compare the effectiveness of petitions and citizen suits to internal agency processes for the listing of species under the ESA. To appreciate the comparison, it is helpful to understand the ESA and its listing process in some detail.

The ESA, primarily administered by the U.S. Fish and Wildlife Service (FWS), is the leading legal tool for protecting biodiversity in the United States. ${ }^{46}$ The ESA is highly controversial, and there have been regular proposals in Congress to weaken or even repeal it. ${ }^{47}$ In the mid-1990s, Congress enacted a temporary prohibition on the listing of new species under the Act because of concerns about the economic costs that resulted from protection of species listed under the Act. ${ }^{48}$

The ESA provides regulatory protection for species that have been listed under the Act as either "endangered" or "threatened."49 Species may be listed either pursuant to the initiative of the FWS or via a petition initiated by any person. ${ }^{50}$

If a species is listed by FWS, the agency will follow the standard procedures for issuance of an informal rule pursuant to the APA. ${ }^{\text {s1 }}$ If a petition is

44. See also House Endangered Species Hearings, supra note 43, at 344 (statement of Rep. Eckhardt, Member, H. Comm. on Merch. Marine \& Fisheries) (referring to an "innovative provision in the Product Safety Act which might answer some of the questions ... with respect to the Interior Department's failing to act, or act properly, in certain cases").

45. See, e.g., 16 U.S.C. $\$ \$ 1533(\mathrm{f}) \&(\mathrm{~g})$.

46. Implementation of the Act with respect to certain marine species is by the Department of Commerce through the National Oceanic and Atmospheric Administration (NOAA). See 16 U.S.C. $\S 1532(16)$. Because of the limited number of species covered by NOAA, and in order to avoid problems with comparing the implementation of the Act by two agencies, we limited our study to those species for which FWS is responsible.

47. See, e.g., Eric Biber, Climate Change and Backlash, 17 N.Y.U. ENVTL. L.J. 1295, 1335 n.113 (2009) (surveying literature and political efforts to revise the ESA).

48. See D. Noah Greenwald, Kieran F. Suckling \& Martin Taylor, The Listing Record, in 1 THE ENDANGERED SPECIES ACT AT THIRTY, at 51, 59-60 (Dale D. Goble et al. eds., 2006) (noting the appropriations ban).

49. See 16 U.S.C. $\S \S 1532(6) \&(20) ;$ id. $\$ 1533$.

50. See id. \$§1533(a)(2)(A), (b)(3)(A).

51. The agency publishes a proposed rule, seeking notice and comment on the proposal, and then publishes a final rule in which it responds to submitted comments. The agency may publish the proposed rule unaltered, responding to comments separately; alter the final rule based on the comments; 
filed with FWS for listing of a species, the ESA specifies a series of procedural steps and deadlines with which the agency must comply. First, within ninety days of receipt of the petition, FWS must determine whether the petition contains information that warrants further review. ${ }^{52}$ If the determination is that it does not, then FWS can dismiss the petition. Otherwise, FWS must, within twelve months of receipt of the petition, reach a conclusion as to whether the species warrants listing. ${ }^{53}$ If FWS concludes that the species does warrant listing, it follows the notice and comment process. ${ }^{54}$ If not-or if the agency rejects the petition at the earlier ninety-day stage, or misses any of the relevant deadlines-then private parties may bring suit to challenge the rejection or delay under both the ESA citizen suit provision and the APA. ${ }^{55}$

In making listing decisions, the ESA requires FWS to consider five listing factors that cover the range of threats that might cause a species to become extinct: habitat destruction; overhunting; disease or predation; inadequate regulatory protection; and any "other natural or manmade factors." is explicitly restricted to considering the "best available commercial and scientific data" in making listing decisions, a requirement that prohibits the agency from considering the economic cost of listing a species. ${ }^{57}$

Listed species receive a range of regulatory protections from both federal and private actions. ${ }^{58}$ FWS also must take affirmative steps to "recover" a listed species so that it no longer requires protection under the Act and can

or even withdraw the proposed rule entirely. See 5 U.S.C. $\$ 553$ (2006) (setting up procedures for rulemaking by agencies).

52. 16 U.S.C. $\S 1533(\mathrm{~b})(3)(\mathrm{A})$.

53. Id. $\S 1533(\mathrm{~b})(3)$ (B). The agency can also conclude that the species warrants listing but that the agency's resources must be used to list other species that are a higher priority. See id. $\S 1533(\mathrm{~b})(3)(\mathrm{B})(\mathrm{iii})$.

54. Id. $\S \S 1533(\mathrm{~b})(5)-(\mathrm{b})(6)(\mathrm{A})$. See supra note 51.

55. For a graphical overview of the petition process, see U.S. FISH \& WILDLIFE SERV., THE PETITION PROCESS (2001), available at http://www.fws.gov/endangered/pdfs/listing/petition.pdf.

56. 16 U.S.C. $\$ \$ 1533(\mathrm{a})(1)(\mathrm{A})-(\mathrm{E})$.

57. Id. § 1533(b)(1)(A); see also H.R. REP. No. 97-835, at 19-20 (1982) (Conf. Rep.), reprinted in 1982 U.S.C.C.A.N. 2860, 2860-61. For a discussion of this provision, see Holly Doremus, Listing Decisions Under the Endangered Species Act: Why Better Science Isn't Always Better Policy, 75 WASH. U. L.Q. 1029, 1049-56 (1997). For case law, see, for example, N.M. Cattle Growers Ass'n v. U.S. Fish \& Wildlife Serv., 248 F.3d 1277, 1282 (10th Cir. 2001); Ariz. Cattle Growers' Ass'n v. Kempthorne, 534 F. Supp. 2d 1013, 1035 (D. Ariz. 2008); Cape Hatteras Access Pres. Alliance v. U.S. Dep't of the Interior, 344 F. Supp. 2d 108, 130 (D.D.C. 2004).

58. Section 7 of the ESA generally prohibits federal agencies from taking actions that would "jeopardize the continued existence" of a listed species or that would result in "adverse modification" of designated critical habitat for the species. 16 U.S.C. $\$ 1536(a)(2)$. Section 9 of the ESA generally prohibits any parties (including private parties and federal and state agencies) from "taking" members of listed species, which can include certain forms of habitat modification. Id. \&1538(a)(1)(B); Babbitt v. Sweet Home Chapter of Cmtys. for a Great Or., 515 U.S. 687 (1995). 
be delisted. ${ }^{59}$ Pursuant to FWS's "recovery program," the agency may spend money on activities such as habitat restoration, captive breeding, control of disease or predators, habitat acquisition, or partnerships with state, local, or private entities. ${ }^{60}$

FWS has rarely had an adequate budget to fully implement the ESA. ${ }^{61}$ For instance, according to FWS, for the past several years it has not been appropriated enough funds to officially list all of the hundreds of species that the agency itself concedes warrant listing under the Act. ${ }^{62}$ Those species that deserve listing but that the agency is unable to list fall into a "warranted but precluded" category established by the ESA, a third option for species that the agency considers for listing. ${ }^{63}$

Likewise, the agency has never had enough funds to fully implement all the activities that would be required to recover all of the species listed under the ESA. ${ }^{64}$ The agency is therefore left with difficult decisions about how to prioritize its limited resources across the range of species proposed for listing and the range of species that are listed and require recovery. To formalize this prioritization process, Congress required FWS to develop ranking systems to help allocate scarce resources for listing and recovery across all the relevant species. ${ }^{65}$ FWS accordingly developed listing priority and recovery priority ranking systems in the $1980 \mathrm{~s}^{66}$ We rely on the recovery priority ranking system because it provides us with the most useful data for our analysis. The

59. 16 U.S.C. $\$ 1533(f)$ (stating that the agency "shall develop and implement plans ... for the conservation and survival of" listed species).

60 . See id. $\$ 1533(\mathrm{f})$ (defining recovery as providing for the "conservation" of listed species); id. $\$ 1532(3)$ (defining conservation as "all methods and procedures" needed to delist the species, including "research, census, law enforcement, habitat acquisition and maintenance, live trapping, and transplantation").

61. See Oliver A. Houck, The Endangered Species Act and Its Implementation by the U.S. Departments of Interior and Commerce, 64 U. COLO. L. REV. 277, 292-96 (1993).

62. Katrina Miriam Wyman, Rethinking the ESA to Reflect Human Dominion Over Nature, 17 N.Y.U. ENVTL. L.J. 490, 495-99 (2008).

63. See 16 U.S.C. $\$ 1533(\mathrm{~b})(3)(\mathrm{B})(\mathrm{iii})(\mathrm{I})$. These are species that the agency concludes merit listing under the Act, but for which the agency does not have resources to complete the listing process because funds have been allocated to "higher priority" species_usually species that FWS believes face more immediate and serious threats to their existence. For a recent example of how FWS applies this provision, see Endangered and Threatened Wildlife and Plants, 74 Fed. Reg. 57,804, 57,813-15 (Nov. 9, 2009) (codified at 50 C.F.R. $\& 17$ (2010)).

64. See Julie K. Miller et al., The Endangered Species Act: Dollars and Sense?, 52 BIOSCIENCE 163 (2002); Daniel J. Rohlf, Section 4 of the Endangered Species Act: Top Ten Issues for the Next Thirty Years, 34 ENVTL. L. 483, 507 (2004); Erik Stokstad, What's Wrong With the Endangered Species Act?, 309 SCIENCE 2150 (2005); Wyman, supra note 62, at 499-502.

65. See 16 U.S.C. $\$ \S 1533(\mathrm{~h})(3)-(4)$.

66. See Endangered and Threatened Species Listing and Recovery Priority Guidelines, Notice, 48 Fed. Reg. 43,098, 43,098-105 (Sept. 21, 1983). 
listing priority data does not provide us with an adequate number of observations to conduct our full analysis. ${ }^{6 ?}$

FWS's recovery priority system ranks species according to (1) the degree to which the species is threatened with extinction; (2) the ease with which the species could be recovered; (3) the level of taxonomic uniqueness of a species; ${ }^{68}$ and (4) whether protection of the species would result in conflict with economic development, in that order of priority. ${ }^{69}$ Higher-priority species are species that are in greater danger of extinction, easier to recover, relatively unique taxonomically, and in conflict with development-in that order. Again, in theory, species ranked higher under the recovery priority system are supposed to be first in line to receive scarce recovery funds. Congress also required FWS to provide regular biennial reports on the progress of its recovery efforts for listed species, and as part of those reports, FWS has reported the recovery priority rankings for all listed species from 1990 to $2004 .^{70}$

\section{Using the ESA Data to Answer Questions About Petitions}

The combination of the ESA petition process with the recovery priority rankings gives us the opportunity to observe how listing decisions differ in terms of outcomes depending on whether they are initiated by a petition or by the agency itself. At the most basic level, we are able to compare the characteristics of species that are listed as a result of a petition with the characteristics of species that are listed on the agency's own initiative.

This in turn can give us some insight as to how the petition process alters the priorities of the agency's agenda-setting. If petitions result in the listing of species that are fundamentally different from the species that are listed

67. We describe the listing priority system, and our reasons for not relying on that data in our analysis, in more detail in the Appendix, infra notes 225-228 and accompanying text. We were able to conduct some of the more basic, descriptive analysis using the listing priority data, and the results do not differ in any significant way. See infra App. Part A.

68. Taxonomic uniqueness refers to whether a species is unique to its genus, a species, or a subspecies. It is a proxy for evolutionary importance of the species. See Endangered and Threatened Species Listing and Recovery Priority Guidelines, Notice, 48 Fed. Reg. 43,098, 43,103-04 (Sept. 21, 1983). We do not use this factor in our analysis.

69. The recovery priority ranking system is an eighteen-point orthographic scale, with an additional notation for the existence of conflict or not. See id. at 43,104 (description of the recovery priority system). The distinction between the second factor (recovery potential) and the final factor (potential for conflict with development) is that the former focuses on the direct costs and difficulty of restoring a species to health (e.g., through active habitat management, captive breeding, control of predators, etc.), while the latter focuses on the regulatory impacts of protecting the species on economic activity. While the two can overlap, they are distinct. If they conflict, the recovery potential factor trumps.

70. See 16 U.S.C. $\$ 1533(\mathrm{f})(3)$ (requiring FWS to report to Congress on the status of the recovery program). 
on the agency's own initiative, we will have some evidence that petitions substantially alter the agency's agenda-setting process.

Indeed, the ESA petition and citizen suit provisions have been sharply criticized as fundamentally undermining FWS's ability to set its agenda. While these criticisms have focused on lawsuits to force the designation of critical habitat for listed species, ${ }^{71}$ some of the criticism has been more general, echoing the criticism developed in the administrative law literature. ${ }^{21}$ In particular, there have been claims that litigation by environmental groups focuses on species that are at lower risk on average. ${ }^{73}$ Thus, the utility of petitions and citizen suits in implementing the ESA is open for debate, lending practical importance to our study.

The ESA listing data also provides us with an unusual opportunity to study in a focused way how petitions affect agency priorities and agendasetting. For much of the time of our study (approximately from 1998 to the present), Congress has imposed a cap on the amount of FWS's budget that can be spent on listing decisions. ${ }^{74}$ In other words, petitions to list specific species only have a direct effect on the species listing budget, not on FWS's total overall budget. ${ }^{75}$ If petitions force FWS to list a large number of species,

71. Critical habitat is a designated geographic area that provides additional regulatory protection for a listed species. See 16 U.S.C. $\S 1532(5)$ (definition), id. § 1533(b)(6) (procedure for designation), id. § 1536(a)(2) (regulatory implications).

72. See, e.g., Endangered Species Act: Critical Habitat Issues: Hearing Before the Subcomm. on Fisheries, Wildlife, $\mathcal{E}$ Water of the S. Comm. on Env't $\mathcal{E}$ Pub. Works, 108th Cong. 6-7 (2004) [hereinafter Senate ESA Hearingl (testimony of Craig Manson, Assistant Secretary for Fish, Wildlife, and Parks, U.S. Department of the Interior, regarding the designation of critical habitat under the Endangered Species Act); Jason M. Patlis, Riders on the Storm, or Navigating the Crosswinds of Appropriations and Administration of the Endangered Species Act: A Play in Five Acts, 16 TUL. ENVTL. L.J. 257, 257-329 (2003); Stuart L. Somach, Essay, What Outrages Me About the Endangered Species Act, 24 ENVTL. L. 801 (1994): Keith W. Rizzardi, Bulk Petitions: Breaking the Endangered Species Act, A Few Hundred Species at a Time?, ESA BLAwG (Aug. 31, 2001), http://www.esablawg.com/esalaw/ESBlawg.nsf/d6plinks/KRII-88H2VY (blog post by leading ESA lawyer and commentator critiquing the "excessive" use of petitions for listing species under the ESA).

73. See Marco Restani \& John M. Marzluff, Funding Extinction? Biological Needs and Political Realities in the Allocation of Resources to Endangered Species Recovery, 52 BIOSCIENCE 169, 174 (2002) ("[N]early three times as many lawsuits were filed on behalf of threatened species as were filed for endangered ones"); see also Wyman, supra note 62, at 496 (stating that "there are reasons to doubt that [environmental groups] routinely sue on behalf of the neediest species") (citing Restani and Marzluff, supra, at 174).

74. See Greenwald et al., supra note 48 , at 61 (noting the appropriations cap). The cap has been less than $\$ 9$ million per year. Id. at $64-65,65$ fig.5.4 (showing historic numbers through 2003). In fiscal year 2009 , the listing budget was $\$ 8.8$ million. Endangered and Threatened Wildlife and Plants, 74 Fed. Reg. 57,804, 57,814 (Nov. 9, 2009) (codified at 50 C.F.R. $\$ 17$ (2010)).

75. The cap includes the designation of critical habitat for listed species, so listing petitions might crowd out resources for designations. Greenwald et al., supra note 48, at 61. However, FWS has consistently indicated that it believes critical habitat designation to have minimal importance, so any such crowding out would be consistent with the agency's own preferences. See, e.g., Senate ESA Hearing, 
that might impact FWS's ability to list species on its own initiative by using up its listing budget, but it would not impinge on FWS's resources for regulatory protections for already-listed species, recovery efforts for already-listed species, or other activities. ${ }^{76}$ As FWS has put it recently, "Congress and the courts," not the agency, "have in effect determined the amount of money available for ... listing activities." Thus, our study is able to "isolate" the implications of petitions for listing decisions from any impacts on the rest of the agency's workload, giving us clearer insight as to how petitions impact a particular regulatory program and reducing the second-order effects of petitions that we need to consider.

We rely on three key components of the recovery priority rankings: the level of threat faced by listed species; the cost to recover listed species; and the possibility that protecting listed species will conflict with important development projects. These three factors in turn have potential relevance for at least two important debates in environmental and administrative law that are connected to the petition and public participation literature: the role of agency expertise; and the possibility that environmental regulatory agencies might suffer from tunnel vision.

It is important to keep in mind as we develop these hypotheses that we are, of necessity, making a comparative study between the performance of outside groups and FWS in identifying species that warrant listing. In this Article, we focus more on the agency than on the outside groups, which serve as a baseline against which we measure the agency's performance. The outside groups that do file petitions or conduct litigation tend to be environmental groups, although as we note later on, there is significant participation by individual scientists, non-environmental scientific organizations, and even state and local agencies. ${ }^{78}$ For purposes of this study, however, we use a somewhat stylized version of these groups as strongly committed to environmental protection and biodiversity, a description that we feel is accurate enough for our present purposes. We hope to explore the nature of the groups

supra note 72. Moreover, critical habitat expenditures have been placed under their own "subcap" within the listing budget, and in recent years the critical habitat subcap has been almost entirely used up for critical habitat designation decisions because of litigation. See Endangered and Threatened Wildlife and Plants, 74 Fed. Reg. at 57,814.

76. Of course, in the long run, increasing the total number of listed species might result in reduced funding for protection and recovery efforts for other listed species. If regulatory and recovery budgets are relatively fixed over time, increasing the total number of listed species through petitions will reduce the per-species availability of funds for regulatory protection and recovery efforts. There are also political or economic impacts based on the regulatory controls imposed by FWS listing decisions, but those costs are not budgetary ones that the agency faced directly.

77. Endangered and Threatened Wildlife and Plants, 74 Fed. Reg. at 57,814.

78. See infra note 111 and accompanying text. 
that submit petitions and participate in ESA litigation further in a forthcoming project.

A second significant caveat is that, by necessity, we cannot observe how FWS might behave in terms of listing species in the absence of petitions or citizen suit litigation. The agency surely must adjust its own listing behavior in the shadow of petitions and litigation activity, but we can only speculate about the nature and scope of such adjustment. Where relevant, we try to provide at least some tentative insights as to how that strategic behavior by the agency might be affecting our results.

\section{Agency Expertise in Identifying Species at Risk}

The recovery priority rankings include the degree of threat that each listed species faces-that is, the risk that a species might become extinct. Prevention of extinction is the fundamental goal of the ESA, ${ }^{79}$ and risk of extinction is the exclusive factor the agency is supposed to use in making listing decisions. ${ }^{80}$ Degree of threat is therefore a proxy for how well petitioners or the agency identify species that warrant listing under the ESA.

The ability of an agency to use technical expertise to fulfill the goals laid out by Congress in the relevant statutes implicates a concept of expertise that has been at the heart of administrative law since before the New Deal era. Up through the 1960s, a primary rationale for the existence of administrative agencies in the United States was that they could provide expertise that would allow the translation of congressional policies into onthe-ground implementation. ${ }^{81}$ If agencies have particular expertise about their specialized mandates, then surely they are more expert than generalist federal judges. Accordingly, courts should show deference to agency decisions,

79. See 16 U.S.C. $§ 1531$ (b) (2006) (asserting that the purpose of the statute is to prevent species extinction); Gifford Pinchot Task Force v. U.S. Fish \& Wildlife Serv., 378 F.3d 1059, 1070 (9th Cir. 2004).

80. See supra note 57.

81. See James M. LANDIS, THE AdMINistrative PROCESS 23, 142 (1938); MARTIN SHAPIRO, WHO GUARDS THE GUARDIANS? 62 (1988); CASS SUNSTEIN, AFTER THE RIGHTS REVOLUTION 23 (1990); Stephen Breyer, Judicial Review of Questions of Law and Policy, 38 ADMIN. L. REV. 363 (1986); James O. Freedman, Expertise and the Administrative Process, 28 ADMIN. L. REV. 363, 363-66 (1976); Ernest Gellhorn, Opening Remarks: Administrative Law in Transition, 38 ADMIN. L. REV. 107, 107-10 (1986); Thomas W. Merrill, Judicial Deference to Executive Precedent, 101 YALE L.J. 969, 1009, 1018 (1992); Richard B. Stewart, The Reformation of American Administrative Law, 88 HARV. L. REV. $1667,1675,1702$ (1975). Some scholars have questioned the expertise of administrative agencies. See Christopher F. EDley, JR., Administrative LaW: Rethinking Judicial CONTROl OF BUREAUCRACY 48-52, 61-66 (1990); Freedman, supra, at 370-72; Louis B. Schwartz, Legal Restriction of Competition in the Regulated Industries: An Abdication of Judicial Responsibility, 67 HARV. L. REV. 436, 471-75(1954). 
and perhaps should keep out altogether. ${ }^{82}$ While scholars have since questioned the notion that administrative agencies can somehow separate political questions from substantive expertise, ${ }^{83}$ courts nonetheless continue to emphasize deference to what they perceive to be technical decisions by an administrative agency ${ }^{84}$ For instance, courts emphasize that they defer to "expert" agencies in reviewing agency decisions based on contested facts, predictions about the future, or complex analyses and models. ${ }^{85}$ This is particularly true in environmental law, where questions of science and technical expertise are almost always near the fore of any lawsuit challenging agency decisionmaking. ${ }^{86}$ There is also a strong intellectual tradition in American natural resources law that emphasizes the role that expertise (as opposed to politics) should play in decisionmaking by government agencies. ${ }^{87}$

In an adversarial system, courts' deference to agencies because of relative expertise implies that courts might also downplay the expertise of outside groups that, as petitioners or plaintiffs, are responsible for developing and bringing information to the court's attention. Indeed, courts appear to be generally more skeptical of information brought by outside groups in challenging agencies' environmental decisions, and to place greater weight on information provided either by the decisionmaking agency or another governmental entity. ${ }^{88}$ Accordingly, if the courts are right, our prediction would

82. See, e.g., Schwartz, supra note 81 , at 439-63 (compiling case law showing deference by courts to agency decisions in economic regulation based on agency "expertise").

83. See, e.g., Wendy E. Wagner, The Science Charade in Toxic Risk Regulation, 95 CoLUM. L. REV. 1613 (1995).

84. See Francis E. ROURKE, BureauCracy, POLITICS, AND PUBliC POLICY 201-02 (3d ed. 1984). There also remains a significant amount of deference to expertise in the political arena (at least in the public realm). Id. at 82,94 (noting particular deference to natural scientists).

85. See, e.g., Balt. Gas \& Elec. Co. v. NRDC, 462 U.S. 87, 103 (1983) (where an agency "is making predictions, within its area of special expertise, at the frontiers of science," then judicial review "must generally be at its most deferential"); Grand Canyon Air Tour Coal. v. FAA, 154 F.3d 455, 476 (D.C. Cir. 1998) (refusing to require the agency to promulgate regulations because the court is "acutely aware of the limits of [its] institutional competence in the highly technical area at issue in this case").

86. See Jason J. Czarnezki, An Empirical Investigation of Judicial Decisionmaking, Statutory Interpretation, and the Chevron Doctrine in Environmental Law, 79 U. COLO. L. REV. 767, 815-20 (2008) (finding evidence of consistent deference to agency decisionmaking based on technical expertise in environmental law).

87. See generally SAMUEL P. HAYS, CONSERVATION AND THE GOSPEL OF EFFICIENCY: THE PROGRESSIVE CONSERVATION MOVEMENT, 1890-1920 (1959) (noting how Progressive notions of apolitical scientific expertise were a dominant force in the creation of natural resource management agencies such as the U.S. Forest Service).

88. See generally Michael C. Blumm \& Stephen R. Brown, Pluralism and the Environment: The Role of Comment Agencies in NEPA Litigation, 14 HARV. ENVTL. L. REV. 277 (1990) (finding that courts are far more likely to find an agency's environmental review document inadequate in response to challenges from outside groups when there are critical comments from other government agencies, as compared to cases where the only criticisms come from outside groups). 
be that the FWS is more "expert" than outside groups, and therefore species that the agency lists on its own initiative should be, on average, more threatened than species petitioned or litigated by outside groups, as FWS is better able to identify the species that are at highest risk.

An assessment of whether and how agencies are relatively expert in setting agendas would directly respond to critics of petitions. In arguing against sweeping petition provisions, those scholars emphasized the costs that petitions can impose by diverting an agency from what it believes to be its optimal priorities. ${ }^{89}$ For the CPSC, these critics point out that the Commission had developed its own internal ranking for consumer product hazards but that petitions sometimes forced the agency to pursue rulemaking proceedings for hazards the agency felt were minimal..$^{90}$

\section{Public Participation and Agency Tunnel Vision}

While our first hypothesis focuses on FWS and outside groups' relative technical expertise in applying biology to legal decisionmaking, our other major hypotheses explore how FWS and outside groups might consider the costs and policy conflicts that listing decisions might cause. We begin by discussing the importance of cost and policy conflicts in the environmental and administrative law literature (the tunnel vision theory); we then explore how the ESA recovery priority factors might provide some insight into these questions.

\section{a. The Tunnel Vision Theory in the Scholarly Literature}

One theme in the environmental law literature is the alleged inefficiency of regulatory priority setting. The claim is that agencies do not focus enough on maximizing the "bang for the buck" and instead regulate hazards that impose significant costs for a minimal improvement in human health, while ignoring regulatory options that could save more lives at less cost." $\mathrm{A}$ commonly proposed solution is greater central review of environmental regulation. ${ }^{92}$

These critiques are part of a larger argument that government regulatory agencies often develop tunnel vision, consistently overspending resources in

89. See supra notes $34-39$ and accompanying text.

90. See Schwartz, supra note 30, at 48-49.

91. The classic critique is STEPHEN BREYER, BREAKING THE VICIOUS CIRCLE (1993), but there are many others in the same vein. See, e.g., Robert W. Hahn \& Cass R. Sunstein, A New Executive Order for Improving Federal Regulation? Deeper and Wider Cost-Benefit Analysis, 150 U. PA. L. REV. 1489, 1489-93 (2002).

92. See BREYER, supta note 91, at 55-81. 
their attempts to achieve their regulatory goals. ${ }^{93}$ The result is excessive regulation and excessive costs. This argument was the primary justification for the development (initially under President Carter, but greatly expanded under President Reagan) of central White House review of regulation through the Office of Management and Budget (OMB), which requires agencies to justify proposed regulations on a cost-benefit basis. ${ }^{94}$ The goal of this central review was to reduce "inefficient" regulations that resulted from a too-narrow focus by the regulating agency.

None of the critics of petitions ever explicitly relied on the tunnel vision argument. However, these scholars do make general arguments that petitions can divert agencies from the most effective use of their limited resources. This necessarily would incorporate the "efficient" use of resources to minimize costs both directly on the agency and on other social goals. ${ }^{96}$ Thus, to the extent that listing petitions under the ESA lead to agenda-setting that results in higher cost, again they might be seen as vindicating the critics of the petition process.

More generally, environmental law has often been framed as a tension between public participation or responsiveness and expert, technocratic decisionmaking. ${ }^{97}$ From this perspective, not only does public participation in the form of petitions or lawsuits lead to random agenda-setting that does not prioritize the most significant problems, but it also encourages or even causes the agency tunnel vision that results in overregulation. ${ }^{98}$ Implicit in this critique

93. See Christopher C. DeMuth \& Douglas H. Ginsburg, White House Review of Agency Rulemaking, 99 HARV. L. REV. 1075, 1081 (1986) (arguing that government agencies will "'spend'through regulations that spend society's resources ... - 'too much"' on achieving their goals); Christopher C. DeMuth \& Douglas H. Ginsburg, Rationalism in Regulation, 108 MICH. L. REV. 877 (2010) (book review) (repeating the argument).

94. See Christopher C. DeMuth, A Strategy for Regulatory Reform, REGULATION, Mar.-Apr. 1984, at 26 (calling OMB review the centerpiece of Reagan's regulatory reform efforts); DeMuth \&Ginsburg, supra note 93, at 1081-82 (noting that the president, through $\mathrm{OMB}$, has to control agency tunnel vision); Harold J. Krent \& Ethan G. Shenkman, Of Citizen Suits and Citizen Sunstein, 91 MICH. L. REV. 1793 (1993); Peter L. Strauss \& Cass R. Sunstein, The Role of the President and OMB in Informal Rulemaking, 38 ADMIN. L. REV. 181, 190, 193 (1986). For an overview of the history of the Executive Orders imposing OMB review, see Hahn \& Sunstein, supra note 91, at 1489-1510.

95. See supra notes 35-38.

96. Merrill, supra note 30, at 1363-64; Schwartz, supra note 30, at 49-52, 56-57.

97. See, e.g., Edward L. Rubin, Getting Past Democracy, 149 U. PA. L. REV. 711, 781-82 (2001).

98. See, e.g., BREYER, supra note 91 (arguing for more insulated bureaucratic decisionmaking for risk regulation based on claims that excessive public involvement leads to random agenda-setting and overregulation); Frank B. Cross, The Public Role in Risk Control, 24 ENVTL. L. 887, 929 (1994) (same); John D. Graham, Legislative Approaches to Achieving More Protection Against Risk at Less Cost, 1997 U. CHI. LEGAL F. 13 (arguing for structuring public involvement in risk management to make "rational" choices because of flaws in public assessment of risk); Cass R. Sunstein, Which Risks First?, 1997 U. CHI. 
is the assumption that outside groups (particularly environmental groups) will ignore the costs of regulation, skewing agency decisionmaking away from efficiency. Thus, any assessment of whether petitions help or hurt agency decisionmaking in the context of environmental law must take into account agency tunnel vision and the role that public participation might play in causing it.

What we focus on here is the question of whether the tunnel vision criticism has validity in the context of a statutory scheme that allows for significant use of petitions. As scholars have noted, there is very little empirical evidence as to whether regulatory agencies consistently have tunnel vision and overfocus on regulatory goals in general, and there is no empirical evidence as to how public participation might affect tunnel vision by an agency. ${ }^{99}$ Most of the examples to date have been the analyses of particular regulations as resulting in excessive costs relative to benefits. ${ }^{100}$ There is scant evidence that agencies are systematically overregulating in the pursuit of their particular goals as opposed to (for example) underregulating, and in fact there are important theoretical reasons to question whether agencies would systematically suffer from tunnel vision. ${ }^{101}$

\section{b. Using the Recovery Priority Data to Explore the Tunnel Vision Theory}

Our data- because it provides a comprehensive view of a particular regulatory program in which petitions are regularly used-has the potential to provide some insight on these issues. The recovery priority factor measures how much it would cost to restore a species such that it would no longer be on the edge of extinction. ${ }^{102}$ If one accepts the argument made (explicitly or implicitly) by the critics that we should generally be using cost-benefit analysis to determine whether agency actions are socially beneficial, then an agency that takes those costs and benefits into account would likely exclude some

LEGAL F. 101 (calling for more stringent OMB review of environmental regulation in response to problems with environmental risk regulation).

99. See Nicholas Bagley \& Richard L. Revesz, Centralized Oversight of the Regulatory State, 106 COLUM. L. REV. 1260, 1283 (2006) (noting that the major studies of whether OMB review reduces regulatory costs are equivocal, undermining the argument that agencies do indeed overregulate).

100. See, e.g., Hahn \& Sunstein, supra note 91 , at 1489-93, 1511-15.

101. See Bagley \& Revesz, supra note 99 , at 1282-1304.

102. Note that this measure is not a measure of the regulatory cost of protecting the species once listed but instead indicates the likely costs of active steps to restore the species to health. However, recovery priority is still useful for our analysis for two reasons. First, it seems plausible that species that will cost a great deal to be restored to health will also often impose significant regulatory costs for protection in the near future. Second, the listing of a species is a commitment by the agency to take steps at some point to attempt to recover the species, 16 U.S.C. $\$ 1536(\mathrm{a})(1)(2006)$, and thus spend money on the species. 
of the highest-cost species from protection. ${ }^{103}$ Some commentators have called on FWS (and if necessary, Congress) to change the implementation of the ESA in precisely this way. ${ }^{104} \mathrm{By}$ comparing the cost to recover the species identified for listing by FWS with the cost to recover species identified by outside groups, we can gain insight as to whether the agency is relatively more cost sensitive.

The third factor-the extent to which protection of the listed species will result in conflict with other development projects-also can help us explore agency tunnel vision. FWS gathers this information from other federal agencies that are pursuing development, surveying whether the ESA has required them to take additional regulatory steps to help protect the species. ${ }^{105}$ Thus, this factor provides a useful measure of the regulatory cost of listing a species. ${ }^{106}$ In addition, the possibility of conflict between the goals of federal agencies was another justification relied upon by those who argued for central review of agency rulemaking decisions by the White House and OMB. ${ }^{107}$ Tunnel vision agencies, the argument went, would so faithfully pursue their particular goals that they would interfere with other important social goals being pursued by other agencies. Central regulatory review and coordination would reduce that risk.

Again, by comparing the "potential for conflict" status of species identified for listing by FWS with the status of species identified through petitions, we can observe whether the agency is relatively more likely than outside groups to consider interagency conflict and regulatory cost, and thus capable of more

103. Any such consideration would be contrary to the terms of the ESA, which prohibits consideration of economic or political factors in listing decisions. See supra note 57.

104. See, e.g., Charles C. MANN \& MARK L. Plummer, NoAh's Choice: The Future OF ENDANGERED SPECIES 226-31 (1995). We take no position in this Article on the normative desirability of such balancing. We note, however, that any balancing should necessarily include the benefits of protecting a species and that a high-cost species might also provide large benefits that justify the cost of protection.

105. Specifically, FWS reviews whether there have been any requests for "consultation" by other federal agencies to determine whether their projects might cause jeopardy to the listed species or adversely modify designated critical habitat. See Endangered and Threatened Species Listing and Recovery Priority Guidelines, Notice, 48 Fed. Reg. 43,098, 43,104 (Sept. 21, 1983).

106. The "potential for conflict" factor is limited in its utility to measure regulatory cost in that it measures potential regulatory impacts only on federal development projects (whether actively managed by the federal government, funded by the federal government, or permitted by the federal government). It accordingly does not consider impacts on purely private development activities, obviously a large part of the regulatory impact of the listing of many species. However, this factor still provides a very useful measure of regulatory impact in that (a) projects that have a significant impact on federal activities will in many cases also have a significant impact on private activities; and (b) many activities that we would consider private still require federal permitting and therefore fall within this measure (for example, federal permits are usually required for construction on privately owned wetlands).

107. See, e.g., DeMuth \& Ginsburg, supra note 93, at 1082. 
efficient or expert agenda-setting when acting on its own than when acting based on input from outside groups.

Our initial hypothesis is that FWS will be relatively more sensitive than outside groups to cost and to potential for conflict. This prediction depends on the interaction of at least three important variables that might affect the extent to which FWS is subject to tunnel vision. First, as noted above, the ESA prohibits FWS from considering cost, conflict, or similar factors in making listing decisions--legally, the agency is supposed to only consider threat to the species. Moreover, this legal mandate is actively monitored and enforced by environmental groups through citizen suits. Indeed, because of this legal mandate, OMB does not review FWS listing decisions. ${ }^{108}$

On the other hand, in making a listing determination, the agency likely has significant leeway. Actual information about the status of the species at the time of a listing decision is usually scant and hard to interpret. ${ }^{109}$ FWS therefore has a great deal of interpretive room in reading the relevant evidence and coming to a conclusion about whether the species warrants listing. Courts give significant deference to technical analyses by FWS in making listing decisions. ${ }^{110}$ Accordingly, if FWS did wish to take into account cost and conflict in making listing decisions, it probably could do so by shading its interpretation of the threat faced by species in particular directions (for instance, interpreting the threat faced by a species proposed for listing as being less important in cases in which listing might result in high costs or high potential for conflict), and still have most of its listing decisions upheld.

Ultimately, we believe the tension between these two lines of thinking is resolved by the fact that we are comparing FWS to outside groups that are extremely unlikely to care about cost or conflict in proposing species for listing. Many of the groups that participate in the petition and litigation process for listing species are environmental groups whose primary or sole focus is the conservation of biodiversity. ${ }^{111}$ Moreover, because it is relatively easy to prepare and submit a petition, a wide range of individuals and groups can participate in the petition process. ${ }^{12}$ Participation will not be limited

108. See, e.g., Exec. Order No. 12,866, 58 Fed. Reg. 51,735, 51,744 (Oct. 4, 1993) ("Nothing in this order shall be construed as displacing the agencies' authority or responsibilities, as authorized by law.").

109. See, e.g., Holly Doremus, Lessons Leamed, in 1 THE ENDANGERED SPECIES ACT AT 30, at 195, 204-05 (Dale D. Goble et al., eds., 2006).

110. See infra note 141 .

111. For instance, of 278 species listed as petitioned in our data, 130 were petitioned by environmental groups, twenty-six by state government agencies, and 105 by scientists or scientific organizations.

112. According to our data, at least 114 listed species were, at some point in time, the subject of a petition by an individual (often a scientist). Groups involved include the Desert Fishes Council and the National Speleological Society, among many others. 
simply to large environmental groups that are repeat players and therefore might have incentives to act strategically in making petition proposals. In other words, we assume that one of the criticisms of public participation in environmental law-that many of the members of the public that do participate will tend to ignore the costs of regulation-has at least some validity.

Thus, even considering that FWS might have some tunnel vision with respect to pursuit of its goals, we should expect it to have less tunnel vision, and therefore be more willing to take into account political and economic realities, than outside groups. This increased sensitivity might result either from external pressure on FWS from the White House or Congress (directly or via political appointees in the agency), or from internal agency balancing of species conservation with other social goals. We thus expect that species that are listed on the agency's own initiative and are not subject to litigation should, on average, cost less to recover and be less likely to result in conflict with development projects being pursued by other agencies. ${ }^{113}$

\section{Adding Citizen Suits}

As with petitions, Congress included citizen suit provisions in statutes such as the Clean Air Act, the Clean Water Act, and the ESA in response to fears about agency capture. ${ }^{114}$ Scholars noted that citizen suit provisions could help to ensure that agencies were not fully "captured" by regulated entities, particularly when implementing environmental statutes with dispersed benefits to the public as a whole but concentrated costs for regulated industry. ${ }^{115}$

Many of the same criticisms leveled against petitions have also been leveled against citizen suits in environmental law. Scholars have argued that citizen suits divert agencies from rational priority-setting by requiring them to attend to low-priority matters. ${ }^{116}$ A related argument is that citizen suits

113. See infra pp. 375-76 for discussion of how the agency's reaction to the possibility of petitions or litigation might affect our results.

114. See 16 U.S.C. $\$ 1540(\mathrm{~g})$ (2006) (laying out the citizen suit provision for the ESA); 33 U.S.C. $\S 1365$ (2006) (Clean Water Act); 42 U.S.C. $\$ 7604$ (2006) (Clean Air Act); Stephen Breyer, Judicial Review of Questions of Law and Policy, 38 ADMIN. L. REV. 363 (1986); Richard B. Stewart, The Reformation of American Administrative Law, 88 HARV. L. REV. 1667, 1685 (1975); Barton H. Thompson Jr., The Continuing Innovation of Citizen Enforcement, 2000 U. ILL. L. REV. 185, 191-92, 202, 204-06.

115. The leading scholarly advocate of using citizen suits in environmental policy was Joseph Sax. See JOSEPH L. SAX, DEFENDNG THE ENVIRONMENT (1971) (arguing for the use of citizen suits to ensure that statutory environmental goals are met).

116. See, e.g., Jonathan H. Adler, Stand or Deliver: Citizen Suits, Standing, and Environmental Protection, 12 DUKE ENVTL. L. \& POL'YF. 39, 51 (2001) ("[M] ost [citizen] suits are filed against the least significant sources" of pollution and environmental harm); Frank B. Cross, Rethinking Environmental Citizen Suits, 8 TEMP. ENVTL. L. \& TECH. J. 55, 68 (1989) ("Citizens may thus have [environmental agencies] chasing less significant violators, at the expense of agency action against more substantial problems."); 
result in overenforcement-either through direct litigation by citizen groups against regulated parties or by forcing the agency to undertake regulatory or enforcement activity. ${ }^{17}$ While overenforcement can encompass a range of claimed problems, a key component is that enforcement and regulatory activity is imposed in relatively low-value areas where the benefits from regulation are minimal-such as violations of the law that result in low environmental harm. ${ }^{118}$ Finally, a number of scholars have questioned the value of judicial review in general, and citizen suits in particular, based on the assertedly greater expertise of agencies compared to courts and the groups that initiate litigation." All of these arguments are used to support claims that citizen suits should be restricted (either directly through statutory change or indirectly through the restriction of standing to sue) or perhaps eliminated entirely. ${ }^{120}$

Michael S. Greve, The Private Enforcement of Environmental Law, 65 TUL. L. REV. 339, 383 (1990) (questioning whether "private parties are better judges of the public good" and the priorities that should guide regulatory agencies); R. Shep Melnick, Administrative Law and Bureaucratic Reality, 44 ADMIN. L. REV. 245, 246 (1992) (arguing that empirical evidence shows that judicial intervention in administrative agency decisions is uniformly negative, forcing "agencies to substitute trivial pursuits for important ones," and stating that there are no "detailed studies of cases in which the courts have improved policymaking").

117. See, e.g., Adler, supra note 116, at 61-63; A.H. Barnett \& Timothy D. Terrell, Economic Observations on Citizen-Suit Provisions of Environmental Legislation, 12 DUKE ENVTL. L. \& POL'Y F. 1, 9-10 (2001); Cross, supra note 116, at 65-66; Greve, supra note 116, at 380-81; Krent \& Shenkman, supra note 94, at 1802-04; Jim Rossi, Participation Rum Amok: The Costs of Mass Participation for Deliberative Agency Decisionmaking, 92 NW. U. L. REV. 173, 222-24 (1997); Matthew C. Stephenson, Public Regulation of Private Enforcement: The Case for Expanding the Role of Administrative Agencies, 91 VA. L. REV. 93, $114-17$ (2005).

118. See Adler, supra note 116, at 62 (claiming that many environmental law violations do not correlate with any substantial environmental harm); Barnett $\&$ Terrell, supra note 117 , at 10 (stating that overenforcement exists where there is prosecution of "less significant offenses" that do "not create enough environmental benefit to justify the use of limited funds . ..."); Cross, supra note 116, at 66 ("[Clitizen suits run the risk of inconsistent and unfair enforcement .... [where] citizens may pursue even small and unavoidable violations of [environmental laws]."); Greve, supra note 116, at 380 (arguing that citizen suits focus on enforcement of "marginal environmental gains"); Krent \& Shenkman, supra note 94, at 1803-04 (noting that agencies' prosecutorial discretion allows the government to "gauge the relative seriousness of particular crimes" and that civil prosecutorial discretion in environmental law raises "similar" issues); Stephenson, supra note 117, at 114-17.

119. See, e.g., R. SHEP MELNICK, REGULATION AND THE COURTS: THE CASE OF THE CLEAN AIR ACT 60-61 (1983); Frank B. Cross, Pragmatic Pathologies of Judicial Review of Administrative Rulemaking, 78 N.C. L. REV. 1013, 1054-55 (2000); Frank B. Cross, Shattering the Fragile Case for Judicial Review of Rulemaking, 85 VA. L. REV. 1243, 1277 (1999); Bruce Fein, Citizen Suit Attomey Fee Shifting Awards: A Critical Examination of Government-"Subsidized" Litigation, 47 LAW \& CONTEMP. PROBS. 211 (1984).

120. See, e.g., Cross, supra note 116 , at 76 (" $[E]$ nvironmental citizen suits should be confined to a more limited role than at present."); Krent \& Shenkman, supra note 94, at 1822-23 (calling for courts to maintain standing requirements to restrict citizen suits); Adler, supra note 116, at 39-40 (same). 
Justice Scalia has relied on these critiques in arguing for a strict application of standing in environmental litigation. ${ }^{121}$

There has been relatively little rigorous investigation of the extent to which citizen suits affect agency decisionmaking. ${ }^{122}$ Our data analysis also allows us to start filling this gap. In particular, we collected data about litigation of FWS listing decisions. Because of the breadth of the ESA citizen suit provision, and because the petition process provides many tight, mandatory deadlines, there is a great potential for litigation over the delay of petition decisions or the denial of petitions altogether. ${ }^{123}$ We can therefore examine whether citizen suit litigation has an impact on FWS's agenda and whether that impact is greater or lesser than the petition process.

Citizen suits are an important subject of study not only for their own sake, but also because of their close connection to the petition process. Citizen suits are an enforcement mechanism for petitions-either to prod an unresponsive agency to answer a petition or to seek redress for an answer that the petitioner sees as inadequate. As we will discuss later in the Article, understanding the role that citizen suits play in the ESA listing process is essential to understanding how petitions might work as well. ${ }^{124}$ For instance, one of the ways in which

121. See Friends of the Earth, Inc. v. Laidlaw Envtl. Servs., 528 U.S. 167, 209-10, 215 (2000) (Scalia, J., dissenting) (criticizing citizen suit provisions for "turn[ing] over to private citizens the function of enforcing the law") (citing Greve, supra note 116, at 355-59).

122. See, e.g., Greve, supra note 116, at 376 (noting a lack of "solid empirical data concerning the effects of citizen enforcement"); Thompson, supra note 114, at 203-06. The exceptions are a qualitative study of litigation challenging EPA regulatory decisions, see Rosemary O'Leary, The Impact of Federal Court Decisions on the Policies and Administration of the U.S. Environmental Protection Agency, 41 ADMIN. L. REV. 549 (1989) (finding mixed impacts of litigation on EPA decisionmaking but little impact in the majority of cases); some quantitative studies of environmental group litigation against polluters under the Clean Air and Clean Water Acts, see, e.g., Kristi M. Smith, Who's Suing Whom?: A Comparison of Government and Citizen Suit Envirommental Enforcement Actions Brought Under EPAAdministered Statutes, 1995-2000, 29 COLUM. J. ENVTL. L. 359 (2004) (finding that citizen suits are predominantly brought by small environmental organizations against both private and public violators); and a set of detailed case studies of the impacts of judicial review in general (and therefore, implicitly, citizen suits as well). See, e.g., JerRY L. MASHAw \& DAVID L. HARFST, THE STRUGGle FOR AUTO SAFETY (1990) (arguing that judicial review of the federal highway safety program prevented the creation of systematic regulations to proactively improve automobile safety, and instead forced the agency to rely on recalls and other reactive measures); MELNICK, supra note 119 (describing judicial interventions in development of the federal air regulatory program in the 1970s and arguing that it resulted in significant expansion of the program, but also significant delays and inefficient rigidities).

123. FWS regularly misses the relevant statutory deadlines for listing species. See U.S. GEN. ACCOUNTING OFFICE, GAO-93-152, ENDANGERED SPECIES: FACTORS ASSOCIATED WITH DELAYED LISTING DECISIONS 5 (1993); Ivan J. Lieben, Political Influences on USFWS Listing Decisions Under the ESA: Time to Rethink Priorities, 27 ENVTL. L. 1323 (1997). Much ESA litigation involves claims by plaintiffs that FWS has unlawfully delayed making decisions on listed species. See infra note 151.

124. See infra notes 176-177 and accompanying text. 
the CPSC petition provisions were so strong was the strict judicial review they imposed in citizen suits challenging agency denials of petitions. ${ }^{125}$

We generally apply the same hypotheses for citizen suits as for petitions. If FWS, as compared to outside groups, focuses more tightly (and appropriately) on the threat of extinction when setting its listing priorities, then it would be more likely to consistently identify and list without litigation species that face greater threat. For lower-threat species, the agency might either reject listing entirely or might delay making a decision beyond the statutory deadlines (perhaps saving scarce listing decision budgets for species that more clearly warrant protection), triggering litigation by outside groups over those species. ${ }^{226}$

We can make similar predictions for cost. Again, assuming that the agency is more likely than outside environmental groups to focus on cost in listing species, the agency might delay or reject listing species that pose higher costs (either for direct recovery expenditures or for regulatory costs). That in turn would provoke litigation by outside groups focusing on those high-cost species.

\section{Overview}

Putting together our various hypotheses and factors, we can come up with a range of typologies of agency behavior based on the three factors for which we have data. On one axis, the agency can be more or less relatively expert compared to outside groups, ranging from expert to inexpert. On the other axis, the agency can be more or less sensitive to cost and conflict than outside groups. An agency that is relatively insensitive to cost and conflict would fall more into the tunnel vision category; an agency that is relatively sensitive to cost and conflict we term a balancing agency. ${ }^{127}$ It is also important to keep in mind that our typology is based on relative comparisons - what we call an expert or balancing FWS is only expert or balancing compared with outside groups. On an absolute scale of whether the agency (for example) sufficiently considers costs and potential for conflict in identifying species to list, one might conclude that FWS does not do enough balancing even if it is identifying species that have lower cost or conflict than outside groups.

Based on our prior discussion, our hypothesis is that FWS will identify species that face greater threats, cost less to recover, and pose a lower risk of

125. See supra note 33 and accompanying text.

126. Indeed, the agency has a listing priority system under which it purports to prioritize the spending of listing funds on making listing decisions for species that face the highest degree of threar. For more details, see infra notes 225-227 and accompanying text.

127. We reiterate that any such balancing would be contrary to the terms of the statute. 
conflict-in other words, FWS will be an expert balancing agency compared to outside groups. ${ }^{128}$

TABLE 1. Typologies of FWS Behavior Based on Comparing FWSInitiated Listings to Petition-Initiated Listings

Cost/Conflict

\begin{tabular}{|c|c|c|c|}
\hline & $\begin{array}{c}\text { Higher* } \\
\text { Cost/Conflict }\end{array}$ & Same & $\begin{array}{c}\text { Lower* } \\
\text { Cost/Conflict }\end{array}$ \\
\hline $\begin{array}{c}\text { Higher* } \\
\text { Threat Level }\end{array}$ & $\begin{array}{l}\text { Expert Tunnel } \\
\text { Vision Agency }\end{array}$ & $\begin{array}{l}\text { Expert } \\
\text { Agency }\end{array}$ & $\begin{array}{c}\text { Expert Balancing } \\
\text { Agency } \\
\text { (Our Hypothesis) }\end{array}$ \\
\hline Same & $\begin{array}{c}\text { Tunnel Vision } \\
\text { Agency }\end{array}$ & Equivalence & Balancing Agency \\
\hline $\begin{array}{c}\text { Lower* } \\
\text { Threat Level }\end{array}$ & $\begin{array}{l}\text { Inexpert Tunnel } \\
\text { Vision Agency }\end{array}$ & $\begin{array}{l}\text { Inexpert } \\
\text { Agency }\end{array}$ & $\begin{array}{c}\text { Inexpert Balancing } \\
\text { Agency }\end{array}$ \\
\hline
\end{tabular}

$*_{\text {for }}$ FWS-initiated as compared to petition-initiated listings

TABLE 2. Hypotheses About Relative Performance of FWS in Identifying Species for Listing

\begin{tabular}{|c|c|c|}
\hline & $\begin{array}{c}\text { Petition vs. } \\
\text { Non-Petition }\end{array}$ & $\begin{array}{c}\text { Litigation vs. } \\
\text { Non-Litigation }\end{array}$ \\
\hline $\begin{array}{c}\text { Threat Faced } \\
\text { by Species }\end{array}$ & $\begin{array}{c}\text { Non-Petition Species } \\
\text { Face Greater Threats }\end{array}$ & $\begin{array}{c}\text { Non-Litigation Species } \\
\text { Face Greater Threats }\end{array}$ \\
\hline $\begin{array}{c}\text { Recovery Potential } \\
\text { (Cost of }\end{array}$ & $\begin{array}{c}\text { Non-Petition Species } \\
\text { Cost Less to Recover }\end{array}$ & $\begin{array}{c}\text { Non-Litigation Species } \\
\text { Cost Less to Recover }\end{array}$ \\
$\begin{array}{c}\text { Pecovering Species) } \\
\begin{array}{c}\text { With Other } \\
\text { Development Projects }\end{array}\end{array}$ & $\begin{array}{c}\text { Non-Petition Species } \\
\text { Have Less Potential } \\
\text { for Conflict }\end{array}$ & $\begin{array}{c}\text { Non-Litigation Species } \\
\text { Have Less Potential } \\
\text { for Conflict }\end{array}$ \\
\hline
\end{tabular}

\section{METHODOLOGY}

Here we provide a brief overview of our methodology, leaving many of the more technical details to the Appendix for the interested reader. Our basic approach is to compare the FWS recovery priority rankings for species that have been listed by FWS on its own initiative with the rankings for species

128. Again, we discuss infra at notes 201-202 and accompanying text the possible impact on our analysis of agencies' strategic behavior in reacting to the possibility of petitions or litigation. 
that FWS listed only after being petitioned to list the species. We similarly compare species that have never been the subject of litigation with species that have been the subject of litigation. We compare these four groups on the three recovery priority factors that FWS has published for each species, using those factors as our dependent variables. ${ }^{129}$

However, before we get into our analysis of listed species, we need to analyze how well outside groups perform in getting species listed in the first place.

\section{A. What About Non-Listed Species?}

A potential problem is that our analysis only focuses on the species that have been listed pursuant to the ESA. However, there are species that are considered for listing - either through the petition/litigation process or by the agency on its own-that end up never being listed. ${ }^{130}$ It might well be that, even if the species listed as a result of petitions or litigation are more or less the same as the species listed by FWS on its own initiative, outside groups

129. Our analysis uses an outcome-based approach with petitions and litigation as an independent variable and the various recovery priority factors as dependent variables. This approach has been taken by economists examining whether decisionmakers show bias in the selection from an underlying population by comparing important characteristics across the members of the population that are selected or excluded by the decisionmakers. See, e.g., IAN AYRES, PERVASIVE PREJUDICE? UNCONVENTIONAL EVIDENCE OF RACE AND GENDER DISCRIMINATION ch.7 (2001) (using bail bond rates to determine whether courts set bail levels disproportionately high for minority criminal defendants); id. at 404-15 (discussing the general utility of outcome-based tests for identifying racial discrimination or disparate treatment); Sanford C. Gordon, Assessing Partisan Bias in Federal Public Comption Prosecutions, 103 AM. POL. SCI. REV. 534, 534-35 (2009); John Knowles, Nicola Persico \& Petra Todd, Racial Bias in Motor Vehicle Searches: Theory and Evidence, 109 J. POL. ECON. 203, 205-07 (2001) (comparing data on whether police are more likely to find contraband on minority motorists who are stopped and searched by the police to determine whether police disproportionately target minority drivers). As with this literature, we place an outcome variable (the threat level, recovery potential, or conflict with development) as a dependent variable, even though we do not posit a direct causal relationship between the independent variables and the dependent variable (e.g., identification of a species by a citizen petition does not mean that the species therefore becomes more threatened). Instead, we are interested in determining whether the two subpopulations (in this case, species identified by petition or not, litigated or not) differ in outcome in a significant way that is meaningful. While we are not attempting to discover intentional discrimination, as these studies generally seek to do, we are seeking to identify differences in a selection process. See AYRES, supra, at 411-12 (noting that outcome-based tests can be useful to identify unintentional discrimination). Additional complications are discussed infra note 131 and accompanying text.

130. It is also the case that ultimately FWS makes the overwhelming number of final listing decisions-there are very few examples of court orders for FWS to list a species. Given the deference that FWS receives in litigation over whether to list a species, petitions or litigation (over delay) play the role of prodding the agency to eventually list a species that it was initially unaware of or reluctant to list. FWS's role as the gatekeeper could allow it to screen out all of the petitioned species that face low threats-as a result, our analysis of the "efficiency" of petitions is also important to ensure that this screening role of FWS is not, in fact, obscuring significant technical expertise on the part of the agency. 
may be much less efficient in listing species than FWS. For instance, it might be that for every five species petitioned, only one is listed, while FWS has a ratio of only listing one species for every two considered. That difference in what we call "efficiency" may be quite significant, as the consideration and rejection of petitioned species may consume significant resources that could be better spent in other directions. ${ }^{131}$

Getting an understanding of the relative efficiency of outside groups and the agency with respect to petition activity is not easy. It is possible to get an estimate of the total number of petitions filed with FWS from outside groups because the agency is required to publish in the Federal Register its findings on the validity of the petitions. ${ }^{132}$ Our preliminary assessment is that from 1973 to 1994 , there were 407 species petitioned for listing under the ESA. ${ }^{133}$ Of those species, 148 species were listed as of 2004, a success rate of 36.4 percent.

The comparison of how many species have been initially considered but rejected by the agency as unsuitable for listing is more challenging to develop. The closest group of species is the various categories of "candidate" species that the agency has maintained over the years, species that FWS is considering for listing but has not yet listed for various reasons. While those categories have

131. This is an example of what Ayres calls the censoring problem for outcome-based analysis. We are only studying the species that are listed, but there may be significant differences between agencyidentified and citizen petition-identified species that are not listed, differences that we do not see because they have been "censored" out from the analysis. See AYRES, supra note 129, at 261. This is an issue that has come up in efforts to examine whether there is racial discrimination in lending. Equal default rates across races for loans that have already been made do not necessarily mean there is not discrimination in the process of approving loans, in part because of this censoring problem. See id.; see also Michael F. Ferguson \& Stephen R. Peters, What Constitutes Evidence of Discrimination in Lending?, 50 J. FIN. 739 (1995). This censoring problem might mean that equal average scores for threat levels for petition and non-petition listed species mask a very different average for threat levels for all petition and non-petition species, listed and non-listed.

132. 16 U.S.C. $\$ \$ 1533$ (b)(3)(A)-(B) (2006).

133. We conducted three searches in the Westlaw Federal Register database: (1) "ca("endangered" \& petition) \& sy("90-day" \% "delist") \& da(bef 1995)"; (2) ca("endangered" \& petition) \& da(bef 1986); and (3) ca("findings on pending petitions" /p "endangered" \%"reclassification"). Our search excluded all delisting petitions, since our focus was on petitions to list species. Only species whose range is within the United States were included in our analysis. There are likely a significant number of petitions from the 1970 s that we were unable to find in our search, in part because Westlaw's coverage of the Federal Register only goes back to 1981 (although many of the petitions filed in the 1970s were not published until the 1980s), and in part because FWS's recordkeeping for petitions from the 1970s was very haphazard. See U.S. GEN. ACCOUNTING OFFICE, CED-79-65, ENDANGERED SPECIES-A CONTROVERSIAL ISSUE NEEDING RESOLUTION 24-26 (1979) (finding that of 154 petitions filed with FWS by 1978, the agency could not account for forty-five, and that prior to 1978, the agency had no central log to track petitions received). We excluded from our analysis all petitions that were filed when the species was already being considered for listing by the agency as a "candidate" species (as indicated in our database or relevant Federal Register notices), or had already been identified for listing in a Smithsonian report (see App. infra notes 229-234 and accompanying text), or was otherwise already identified by other agencies. When we found them, we did include species that were listed as a result of petitions filed before 1981. 
changed significantly over time, ${ }^{134}$ they still provide some useful information. Of the animal species that FWS included in its top two candidate categories (Category 1 and 2) (135 $^{19} 1984$ whose review was not initiated by a citizen petition, approximately 21.0 percent were listed as of $2004 .{ }^{136}$ A similar report was produced by FWS in 1994, and of those species, approximately 3.4 percent were listed as of 2004..$^{137}$

Another comparison draws on the fact that a substantial number of the plant species listed under the ESA or being considered as "candidate" species were identified in a series of reports prepared by another government agency, the Smithsonian, in the 1970s. ${ }^{138}$ More than 3000 species were included in the Smithsonian's first report in $1975 .{ }^{139}$ Of these species initially identified by

134. See Endangered and Threatened Wildlife and Plants, 61 Fed. Reg. 64,481 (Dec. 5, 1996) (codified at 50 C.F.R. $\$ 17(2010)$ ) (terminating the prior three-tier system of identifying species as candidates for listing).

135. Category 1 candidate species corresponded to the "warranted but precluded" category under the ESA. Category 2 candidate species corresponded to species for which FWS had information indicating that listing was "possibly appropriate" but for which "persuasive evidence" on threat was not "currently available to support proposed rules." Endangered and Threatened Wildlife and Plants; Animal Candidate Review, 59 Fed. Reg. 58,982 (Nov. 15, 1994) (codified at 50 C.F.R. $§ 17$ (2009)) (quoting 58 Fed. Reg. 28,034 (May 12, 1993)). Category 3 candidate species, which are not included in our analysis, were species that were once "considered for listing ... but are no longer under such consideration ...." Id.

136. We counted the number of species that were included in two comprehensive listings of animal candidate species published by FWS in 1982 and 1984. Endangered and Threatened Wildlife and Plants; Review of Vertebrate Wildlife for Listing as Endangered or Threatened Species, 47 Fed. Reg. 58,454 (Dec. 30, 1982) (codified at 50 C.F.R. \& 17 (2010)) (listing vertebrate candidate species); Endangered and Threatened Wildlife and Plants; Review of Invertebrate Wildlife for Listing as Endangered or Threatened Species, 49 Fed. Reg. 21,664 (May 22, 1984) (codified at 50 C.F.R. $\$ 17$ (2010)) (listing the total number of invertebrate candidate species as 1101). We then counted the number of animal species that we were able to identify as (1) petitioned prior to 1982 or 1984; (2) designated as a candidate species by the agency in response to the petition; and (3) not listed as of 1982 or 1984 (or never listed) (total number seventy-two). We subtracted those species from our overall totals for 1982 and 1984 (in order to exclude species from our candidate list that were likely on that candidate list because of a prior petition). This gave us a total number of 1029 "agency-initiated" candidate species in 1982 and 1984 . We then divided this number into the total number of agency-initiated animal candidate species that, in 2004, were listed after 1982 or 1984 and had not been initiated by petition (a total of 216). This gave us a rough estimate of the proportion of agency-initiated animal candidate species in 1982 and 1984 that were listed as of 2004.

137. We undertook the same methodology as above but using 1994 as the cutoff date and using the animal species listed in Endangered and Threatened Wildlife and Plants; Animal Candidate Review, 59 Fed. Reg. 58,982 (Nov. 15, 1994) (codified at 50 C.F.R. $\$ 17$ (2010)). Total number of Candidate 1 and 2 species in the report was 2005; number of animal species subtracted because they were likely on the list as a result of a petition was seventy-two; total number of agency-initiated Candidate 1 and 2 species in 1994 was 1933; total number of animal species listed berween 1994 and 2004 and not initiated by a petition was sixty-six.

138. For more details, see App. infra notes 229-234 and accompanying text.

139. Threatened or Endangered Fauna or Flora, Notice, 40 Fed. Reg. 27,823, 27,823-24 (July $1,1975)$. 
the Smithsonian in 1975 , our database shows that 492 species were eventually listed, a success rate of less than 20 percent.

We emphasize that these are all very rough estimates. But given the general trend of the figures, we are comfortable with an assessment that there is little difference between petitions and agency-initiation in overall listing success rates. ${ }^{140}$

The same "efficiency" concern could be raised about the litigation process-since we only have data about listed species, we are excluding species which were the subject of litigation but whose non-listing by FWS was upheld by the courts. It might be that for every species listed because of litigation (or listed more quickly because of litigation), there are multiple species for which litigation was ineffective in forcing listing, and was perhaps a waste of agency, court, and citizen-group time and energy because the threats the species in question faced did not warrant listing. Unfortunately, however, it is probably impossible to get a good assessment of how much litigation was "wasted." It is true that there are numerous cases in which FWS has successfully defended its refusal to list a species when challenged by environmental groups. ${ }^{141}$ But those cases cannot be simply counted as evidence that the species in question did not warrant listing because courts generally grant significant deference to FWS when its decisions not to list species are challenged in court. In these cases, it might well be that if we did have good data about the threat level faced by the species, the agency would be shown to have made a mistake in refusing to list the species, but the agency's decision was nonetheless upheld because of judicial deference.

\section{B. Overview of Our Analysis of Listed Species}

We collected data for all species listed as endangered or threatened by FWS pursuant to the ESA and included in the Service's Recovery Report to Congress in $2004 .{ }^{142}$ From the 2004 Recovery Report we obtained the year the species was listed.

140. We do not have historic data about the level of threat faced by these petitioned, unlisted species at the time they were petitioned. We therefore cannot answer the question of whether-even if petitions are more efficient in listing species than FWS_-petitioned, unlisted species overall faced lesser threats than agency-considered, unlisted species.

141. See, e.g., Am. Wildlands v. Kempthome, 530 F.3d 991 (D.C. Cir. 2008); Nw. Ecosystem Alliance v. U.S. Fish \& Wildlife Serv., 475 F.3d 1136 (9th Cir. 2007); Sw. Ctr. for Biological Diversity v. Babbitt, 215 F.3d 58 (D.C. Cir. 2000).

142. Approximately 125 species were listed after the 2004 recovery report's publication and accordingly were excluded from the analysis. Compare U.S. FISH \& WILDLIFE SERV., U.S. DEP'T OF INTERIOR, FY 03-04, REPORT TO CONGRESS ON THE RECOVERY OF THREATENED AND ENDANGERED 
A significant challenge for our data analysis is that FWS only began producing recovery reports for Congress in 1990, and we do not have recovery priority scores before that date. Because our focus is on the status of the species up until the listing decision, we excluded all species that did not have a recovery priority ranking within four years of the date of listing. ${ }^{143}$ This meant that all species listed prior to 1986 were excluded from our analysis. ${ }^{144}$ We then determined the species' first recovery priority ranking after listing (again, within the constraints that the ranking must have occurred within four years of listing). ${ }^{145}$ We disaggregated the overall recovery priority ranking into its individual components - threat, recovery potential, taxonomic uniqueness, and presence of conflict-so that we could focus on the particular scores that

SPECIES 18 (2004) (stating that 1251 species were covered in the 2004 report) with U.S. FiSH \& WILDLIFE SERV., SPECIES REPORTS: ENVIRONMENTAL CONSERVATION ONLINE SYSTEM, http://ecos.fws.gov/tess public/TESSBoxscore (last visited Nov. 10, 2010) (showing 1375 species listed). We only included species listed domestically within the United States.

143. We believe that up to four years of protection under the ESA probably will not change the status of a species significantly. Prior research indicates that most species do not change their recovery priority status over short periods of time. See Timothy D. Male \& Michael J. Bean, Measuring Progress in U.S. Endangered Species Conservation, 8 ECOLOGY LETTERS 986, 987 (2005) (reporting that more than 75 percent of all listed species never changed their priority rank over time); id. at 990-91 (finding that the status of species listed under the ESA generally takes at least a few years before it begins to significantly improve); Jeffrey J. Rachlinski, Noah by the Numbers: An Empirical Evaluation of the Endangered Species Act, 82 CORNELL L. REV. 356, 370-78 (1997) (book review) (finding that there is relatively little improvement in the status of species over a four-year timeframe and that significant improvements in species status require at least several years of listing under the ESA).

There are two ways of understanding our comparison between the agency and outside groups' efforts to identify species through petitions or litigation. On the one hand, a petition or lawsuit can be seen as an effort to predict (for instance) whether the species will be in trouble in the future (or whether, when we have better information in the future, the species will be determined to face serious threats). Based on this prediction perspective, the comparison between petitioned and non-petitioned species, or litigated and non-litigated species, is a comparison about the future (e.g., about the time when the species are listed). From this perspective, the comparison should focus on recovery priority scores given at the time of, or shortly after, listing. The other perspective is that the comparison is about the present-i.e., whether the group petitioning or litigating is better able than FWS to observe at that time whether the species is (for instance) facing greater threats. From this observational perspective, the key time for our comparison of rankings for different species is actually the time at which a species is petitioned (or not) or litigated (or not), which is usually significantly before listing. However, we do not think that any time gap between the initial petition or lawsuit and the time of listing results in a significant bias in our analysis. For more details, see our discussion of the listing priority rankings and the time gap between the time of petition or litigation and the time of listing in the Appendix, infra notes 225-228, 246-249 and accompanying text.

144. Excluded were a total of 360 species, primarily mammals, birds, flowering plants, and fish. (Of the excluded species, forty-nine were mammals, sixty-seven were birds, 110 were flowering plants, and sixty-four were fish- - totaling over 80 percent of the excluded species.).

145. To the extent that the recovery priority rankings help determine funding, and funding determines species status, then species that are ranked highly might also be more likely to recover more quickly, and therefore have their priority rankings reduced. By using the recovery priority ranking closest in time to the listing of the species, we reduced this possibility of endogeneity. 
were relevant to our analysis. These three scores were our independent variables in our regression analysis. We also compared FWS's threat rankings with outside threat rankings to determine whether FWS was manipulating its assessments. We did not find any evidence of manipulation. ${ }^{146}$

We acquired information about both the litigation and petition history for the species in our analysis from the Federal Register documents announcing the listing of the species. ${ }^{147}$ Species were only coded as the subject of a petition if the petition initiated the review of the species in the ESA process. ${ }^{148}$ Petitions that were submitted while the species was already being considered a candidate for listing by the FWS were not counted as petitioned species. ${ }^{199}$ Species were coded as the subject of litigation so long as there was any litigation over the listing of the species-whether the litigation concerned an FWS decision to refuse to list the species at all or an FWS failure to meet statutory deadlines for making listing decisions. ${ }^{150}$

Both to confirm our original coding, and also because the Federal Register documents often did not provide a full description of all prior litigation over individual species, we also consulted a database of ESA listing petitions and litigation maintained by the Center for Biological Diversity (CBD), an environmental group that is a party to a significant number of ESA lawsuits. We found that our coding with respect to petitions was very reliable. The CBD database primarily resulted in adding a significant number of lawsuits to our database,

146. See Appendix infra notes 238-245 and accompanying text for more details.

147. The Federal Register items announcing the listing of a species pursuant to the ESA generally contain a background section that discusses the history of FWS's decisionmaking process, including listing petitions from outside groups.

148. The major complication is the treatment of plant species identified by the Smithsonian as potential candidates for listing. We count these as non-petitioned species. See Appendix infra notes 229234 and accompanying text for more details.

149. "Candidate" species are a category of species that FWS has considered or is considering for listing but has not yet listed under the Act. The definition of this term has changed over time. Endangered and Threatened Wildlife and Plants, 61 Fed. Reg. 64,481, 64,484 (Dec. 5, 1996) (codified at 50 C.F.R. $\$ 17$ (2010)). Excluding species that were the subject of a petition after they already had been designated as a candidate by FWS ensured that our analysis answered the question that we were most interested in: whether it was FWS or an outside group that first identified a species as worthy of listing under the ESA.

150. From our review of the data, the vast majority of litigation apparently involved delay by FWS as opposed to the agency's decision not to list a species. From what we could determine from the relevant data sources, only five out of a total of 434 listed species that were the subject of litigation involved litigation over the agency's refusal to list a species, as opposed to delay by the agency. In many cases, however, the information that we had available did not allow us to determine whether a particular lawsuit involved a challenge to FWS delay, the merits of an FWS decision, or both. As a result, we coded only for the existence of litigation, not the type of litigation. 
including lawsuits that challenged alleged delays for hundreds of species that were eventually listed. ${ }^{151}$

There were a number of additional factors that we considered in our analysis. First, there could be a concern that there is a selection bias in terms of the species that either FWS or outside groups are likely to consider for listing and/or litigation: They may only focus on charismatic, popular species for which they can receive monetary and political support. If this is the case, then some taxonomic groups are likely to be listed (if at all) only when they are otherwise ranked higher on the recovery priority system (that is, when they have higher threat, higher recovery potential, or more potential for conflict). There is some evidence that this kind of bias exists. ${ }^{152}$ In order to control for any potential bias, we included dummy variables for the taxonomic group that the species is part of (mammal, bird, fish, reptile or amphibian, mussel, insect, arachnid, plant, fungus, and so forth). We generally would expect that charismatic groups such as mammals and birds would be more likely to be listed even if they face lower threats, are harder to recover, or have more potential for conflict-while non-charismatic groups (all others) would be less likely to be listed, and so would only receive protection if they are in serious trouble, are easier to recover, or do not present conflicts with development projects.

151. Most species involved in litigation were the subject of only a few lawsuits that challenged delays by FWS relating to hundreds of species. See, e.g., Fund for Animals v. Babbitt, Civ. No. 92 00800-SS (D.D.C. 1992) (challenging delay in listing over four-hundred species, resulting in a settlement agreement outlining a schedule for listing species); Conservation Council for Haw. v. Lujan, Civ. No. 98-00953-ACK (D. Haw. 1989) (challenging delay in listing over 160 Hawaiian plant species, also resulting in a settlement agreement to list species over a scheduled timeframe) (described in Conservation Council for Hawaii v. Lujan, 2 F. Supp. 2d 1280, 1281 n.1 (D. Haw. 1998)); California Native Plant Society v. Lujan, CIV 91-0038 (E.D. Cal. 1991) (challenging delay in listing over fifty California plant species, likewise resulting in a settlement agreement to list the species over time). For details about these lawsuits and the settlement agreements, see Eric R. Glitzenstein, On the USFWS Settlement Regarding Federal Listing of Endangered Species, ENDANGERED SPECIES UPDATE, Mar. 1993, at 1; Lieben, supra note 123 , at 1327 n.23, $1350,1355$.

The CBD database that we used generally included only species for which review had begun prior to 1996 (with a few exceptions). However, only a tiny fraction (less than twenty) of the species listed in the 2004 Recovery Report had begun review in 1996 or later.

152. See, e.g., Eric Biber, Comment, The Application of the Endangered Species Act to the Protection of Freshwater Mussels: A Case Study, 32 ENVTL. L. 91, 154-61 (2002) (developing evidence that an uncharismatic group of species, freshwater mussels, receive less enforcement protection and recovery funding and less attention from environmental groups than other, more charismatic taxonomic groups). In 1988, Congress amended the ESA to prohibit preferential treatment in developing and implementing recovery plans for species based on their "taxonomic classification" (i.e., whether the species is a plant, animal, vertebrate, or invertebrate), in part in response to reports that FWS was consistently preferring charismatic species in funding recovery programs. See Endangered Species Act Amendments of 1988, Pub. L. No. 100-478, 102 Stat. 2306, 2307; see also Federico Cheever, The Road to Recovery: A New Way of Thinking About the Endangered Species Act, 23 ECOLOGY L.Q. 1, 38-40 (1996) (describing the history of this amendment). 
There is also substantial evidence that, at least on occasion, politics is relevant for FWS's decisionmaking under the ESA. One study has found that agency decisions about whether to list subspecies under the ESA are strongly influenced by the composition of the relevant Appropriations subcommittee in Congress, and whether a species's range places it within the district of powerful members of the relevant Appropriations subcommittee. ${ }^{153}$ Political interference in the listing process could have a significant impact on our analysis-if there is significant resistance to the listing of a species due to political pressure (either from within the executive branch or from Congress), then species that face adverse political pressure will likely be listed only after a significant period of delay and will therefore likely be ranked higher on the recovery priority scale. ${ }^{154}$ Accordingly, we collected data about the political landscape for each species at the time it was listed, noting both the party of the president at the time the species was listed as well as the League of Conservation Voters scores of the senators who held important, relevant subcommittee positions (either on the relevant subcommittee of the Environment and Public Works Committee or the Interior subcommittee of the Appropriations Committee) at the time the species was listed. ${ }^{155}$

Finally, we noted a consistent trend in which the level of litigation over species listings increased over time, and a consistent trend in which the threat level for species increased over time (that is, species listed later in time consistently faced higher threats in FWS's recovery priority rankings). Because of

153. See J.R. DeShazo \& Jody Freeman, The Congressional Competition to Control Delegated Power, 81 TEX. L. REV. 1443, 1471-87 (2003) (finding that the composition of relevant congressional subcommittees is more important in determining whether subspecies are listed as endangered than how endangered the subspecies actually is); see also U.S. GEN. ACCOUNTING OFFICE, GAO-93-152, ENDANGERED SPECIES: FACTORS ASSOCIATED WITH DELAYED LISTING DECISIONS, 5, 8-9 (1993) (finding that political pressure related to the economic impact of listing proposals led to delays in making listing decisions in specific case studies); Amy Whitenour Ando, Waiting to Be Protected Under the Endangered Species Act: The Political Economy of Regulatory Delay, 42 J.L. \& ECON. 29, 44-52 (1999) (finding that congressional and public pressure on FWS affects the time it takes for the agency to decide whether to list a species); Bonnie Harllee et al., Political Influence on Historical ESA Listings by State: A Conmt Data Analysis, 140 PUB. CHOICE 39 (2009) (finding that the composition of relevant congressional subcommittees influences the number of species listed each year in a state); Lieben, supra note 123, at 1365 (arguing that political pressure on FWS to not list species is pervasive). But see Paul J. Ferraro, Craig McIntosh \& Monica Ospina, The Effectiveness of the U.S. Endangered Species Act: An Econometric Analysis Using Matching Methods, 54 J. ENVTL. EOON. \& MGMT. 245, 249 (2007) (finding no significant impact of politics on listing decisions between 1982 and 1993).

154. For instance, species that are listed in spite of political pressure might only be listed once the threats have become so overwhelming that the agency has no choice but to list (i.e., a higher threat level than for species not facing political pressure).

155. We provide further details in the Appendix, infra notes 236-239 and accompanying text. 
these consistent patterns, we included a "Year Listed" variable as a control in our analysis. ${ }^{156}$

\section{RESULTS}

As a preliminary matter, we began by doing some simple analyses of listed species for the three characteristics of interest (threat level, recovery potential, and existence of development conflict), comparing those that were the subject of petitions with those that were not the subject of petitions, and those that were the subject of litigation with those that were not the subject of litigation. ${ }^{157}$

TABLE 3. Average Threat Level, Recovery Potential, and Conflict Score of Listed Species, According to Petition and Litigation Status

\begin{tabular}{|c|c|c|c|c|}
\hline & Petition & No Petition & Litigation & No Litigation \\
\hline Threat Level & 1.28 & 1.33 & $1.27^{* *}$ & $1.37^{* *}$ \\
\hline $\begin{array}{c}\text { Recovery } \\
\text { Potential }\end{array}$ & 1.28 & 1.40 & $1.35^{*}$ & $1.43^{*}$ \\
\hline Conflict & $0.42^{* *}$ & $0.18^{* *}$ & 0.24 & 0.2 \\
\hline
\end{tabular}

Values are mean subcomponent score for all species in the relevant category.

Threat Level: $1=$ Highest Threat, 2 = Medium Threat, 3 = Lowest Threat

Recovery Potential: $1=$ High, 2 = Low

Conflict: $0=$ No Conflict, 1 = Conflict

$*=$ Difference is significant at 0.05 level;

** = significant at 0.01 level

With respect to threat level, species that were the subject of litigation were consistently at greater threat than non-litigated species. As between petition-identified and agency-identified species, however, we found no statistically significant difference in threat level.

With respect to recovery potential, we again found that species that were the subject of litigation had consistently higher recovery potential (lower estimated cost to recover). Petitioned species also showed somewhat higher recovery potential, but unlike for litigated species, the difference for petitioned species was not statistically significant.

Finally, with respect to potential development conflicts, petitioned species were more likely to present potential conflicts than agency-identified

156. See App., infra notes 246-249, figs.2-3 and accompanying text.

157. Because all of the variables were either binary or ordinal, we used a non-parametric testWilcoxon rank sum test-to perform our analysis. 
species, but no statistically significant difference was identifiable for litigated versus non-litigated species.

Our preliminary analysis therefore indicates that petitioned and litigated species are species that FWS, under its own criteria, thinks are at least as or more "worthy" of protection under the ESA than the species that are identified by the agency on its own or that are not the subject of litigation.

However, as noted above, these preliminary analyses do not take into account a range of potential confounding factors, including politics, taxonomy, and the year that the species was listed. We accordingly conducted logistic regression analysis for all three of our dependent variables that came from the recovery priority rankings, using independent variables to control for the potentially confounding factors. The results of our analysis are listed in Table 4.

TABLE 4. Results of Logistic Regression Analysis

\begin{tabular}{|c|c|c|c|}
\hline & \multicolumn{3}{|c|}{$\begin{array}{l}\text { Recovery Priority Score Subcomponents } \\
\text { (Dependent Variables) }\end{array}$} \\
\hline $\begin{array}{l}\text { Independent } \\
\text { Variables }\end{array}$ & Threat Level & $\begin{array}{l}\text { Recovery } \\
\text { Potential }\end{array}$ & Conflict \\
\hline Petition & $-0.26(0.264)$ & $-0.30(0.250)$ & $0.30(0.26)$ \\
\hline Litigation & $-0.13(0.202)$ & $-0.22(0.191)$ & $0.55(0.25)^{* *}$ \\
\hline Presidential Party & $0.15(0.233)$ & $-0.29(0.216)$ & $-0.42(0.260)$ \\
\hline Interior LCV & $-0.012(0.005)^{* * *}$ & $-0.006(0.004)$ & $-0.001(0.005)$ \\
\hline EPW LCV & $0.005(0.005)$ & $-0.002(0.005)$ & $0.008(0.006)$ \\
\hline Year Listed & $-0.05(0.033)$ & $0.01(0.030)$ & $-0.04(0.036)$ \\
\hline \multicolumn{4}{|l|}{ Taxonomic Group } \\
\hline Arachnid & $-8.49(31.50)$ & $-1.25(1.334)$ & $3.51(1.302)^{* * *}$ \\
\hline Bird & $-0.44(0.852)$ & $-0.10(0.957)$ & $0.46(0.86)$ \\
\hline Crustacean & $-0.03(0.881)$ & $0.62(0.959)$ & $0.69(0.89)$ \\
\hline Fish & $-0.50(0.797)$ & $0.95(0.874)$ & $0.69(0.816)$ \\
\hline Flowering Plant & $-0.32(0.738)$ & $0.49(0.830)$ & $-0.77(0.767)$ \\
\hline Insect & $-0.87(0.872)$ & $0.33(0.910)$ & $1.21(0.830)$ \\
\hline Mammal & $-0.68(0.862)$ & $0.61(0.904)$ & $0.95(0.835)$ \\
\hline Mussel & $-1.21(0.832)$ & $2.29(0.913)^{* * *}$ & $-0.61(0.89)$ \\
\hline $\begin{array}{l}\text { Non-Flowering } \\
\text { Plant }\end{array}$ & $-0.05(0.830)$ & $1.26(0.911)$ & $-2.51(1.277)^{* *}$ \\
\hline Reptile & $1.26(0.898)$ & $-0.67(1.121)$ & $0.72(0.928)$ \\
\hline Snail & $0.62(0.833)$ & $1.04(0.915)$ & $-0.82(0.974)$ \\
\hline $\mathbf{R}^{2}$ & 0.09 & 0.10 & 0.19 \\
\hline
\end{tabular}

$N=824$. Standard errors are in parentheses. 
Threat Level: 1 = Highest Threat, 2 = Medium Threat, 3 = Lowest Threat

Recovery Potential: 1 = High, 2 = Low

Conflict: $0=$ No Conflict, 1 = Conflict

Petition: $0=$ No Petition, 1 = Petition

Litigation: $0=$ No Litigation, $1=$ Litigation

Presidential Party: $0=$ Democrat, $1=$ Republican

Interior LCV: Mean score of LCV rating for all senators on Interior Subcommittee of the Senate Appropriations Committee who represented states within the range of the species at the time the species was listed

EPW LCV: Mean score of LCV rating for all senators on relevant subcommittee of the Senate Environment and Public Works Committee who represented states within the range of the species at the time the species was listed

Year Listed: Year species was listed

Variable coefficient is:

* = significant at 0.1 level

** = significant at 0.05 level

$* * *=$ significant at 0.01 level

Threat Level: Both petition and litigation activity were correlated with higher risks that the species might go extinct (that is, numerically lower threat levels)_although neither coefficient was statistically significant. Having an environmentally friendly senator in a position of power had only a limited impact. Species with such a friend on the Interior Appropriations Subcommittee were listed when they faced a higher risk of extinction (a numerically lower threat level) - the opposite of our original hypothesis (described in detail in the Appendix). On the other hand, we were unable to detect a statistically significant relationship between the political party of the president and the threat level of listed species. None of the taxonomic groups were correlated in a significant way with listing at a higher risk of extinction-in general, no consistent or strong pattern with respect to taxonomic group emerged from the analysis.

Recovery Potential: Neither petition status nor litigation had a statistically significant correlation with recovery potential. Only one of the taxonomic groups had a statistically significant positive relationship with recovery potential (mussels), and once again there was no consistent relationship between taxonomy and recovery potential. Neither congressional nor presidential 
politics again was very relevant to recovery potential, with no statistically significant relationships.

Conflict: Finally, conflict had a significantly positive correlation with litigation-in other words, species that were the subject of litigation were likely to also be in conflict with development projects. There was not a statistically significant correlation between petition status and conflict, however. Few taxonomic groups had statistically significant correlations with conflict status, and again no consistent patterns developed. Political pressure also did not appear to be very important, with no statistically significant relationships for the political control variables.

For the issues that we are most interested in-the relationships between petition and litigation status and the various dependent variables-we find non-statistically significant results in five of the six correlations. These types of results are particularly challenging to interpret, because in the absence of statistically significant differences, we cannot say that we have proven that there is no difference between petitioned and non-petitioned species or litigated and non-litigated species. ${ }^{158}$ All we can say is that we are unable to prove that there is a difference. It is possible that (for instance) if more species were included in a reanalysis (thereby improving the sample size and statistical power), we might find that the differences we did detect would be statistically significant. ${ }^{159}$

Nonetheless, we feel confident in stating that even if there is, in fact, a difference between petitioned and non-petitioned species or litigated and non-litigated species, the differences either (a) are relatively trivial or (b) show that outside groups are more effective in identifying species at risk or less costly species to recover. First, further analysis that we conducted gives us some additional confidence that our estimates of the coefficients for petition and litigation status are accurate. ${ }^{160}$ Second, while not statistically significant, the direction of the correlation cuts in favor of outside groups being better able to identify species at risk that cost less to recover. ${ }^{161}$ Thus, even if differences between outside groups and the agencies do exist, the differences are more likely to show greater expertise on the part of outside groups. Finally,

158. See Berry J. Brosi \& Eric G. Biber, Statistical Inference, Type II Error, and Making Decisionmaking Under the US Endangered Species Act, 7 FRONTIERS ECOLOGY \& ENV'T 487, 487-88 (2009).

159. Given our large sample size $(\mathrm{N}=824)$, our ability to detect any meaningful differences, should they exist, is fairly high.

160. We reanalyzed our data using bootstrapping techniques ( $>1499$ replications) and found that our coefficient estimates remained essentially identical.

161. In our model, the non-statistically significant coefficients for the relationship between litigation and petition independent variables and the threat and cost dependent variables are all negative. 
in the unlikely event that the differences that we detected cut in favor of agency expertise (that is, the coefficients are positive for the relationships between litigation/petition and threat/cost), any such differences are likely quite small and relatively meaningless in terms of real-world differences.

Those last two points are more evident once we translate the coefficients in our logistic regression (which are rather non-intuitive even for those who are statistically proficient) into "predicted probabilities," as we do in Table 5. Predicted probabilities give the likelihood that any individual species will fall into one or another of the dependent variable categories depending on whether the species is the subject of litigation or a petition. For instance, our regression predicts that species subject to petitions are 4.7 percent more likely than non-petitioned species to be categorized by FWS as posing a probable development conflict. And based on the standard errors in our regression, we would have 95 percent confidence that a petitioned species will be anywhere from 3.6 percent less likely to pose a conflict to 13.1 percent more likely to pose a conflict.

TABLE 5. How Petition or Litigation Status Affects the Probability of a Species Falling Within Various Dependent Variable Categories

\begin{tabular}{|c|c|c|}
\hline $\begin{array}{c}\text { Dependent } \\
\text { Variable } \\
\text { Category }\end{array}$ & $\begin{array}{c}\text { If a species is the subject of a } \\
\text { petition, its probability of falling } \\
\text { within the category changes by: }\end{array}$ & $\begin{array}{c}\text { If a species is the subject of } \\
\text { litigation, its probability of falling } \\
\text { within the category changes by: }\end{array}$ \\
\hline $\begin{array}{c}\text { High } \\
\text { Threat } \\
\text { Level }\end{array}$ & $\begin{array}{c}\text { Increasing by } 4.8 \text { percent, from } \\
71.1 \text { percent to } 75.9 \text { percent } \\
(-4.9 \text { percent to }+14.6 \text { percent })\end{array}$ & $\begin{array}{c}\text { Increasing by } 2.5 \text { percent, from } \\
71.1 \text { percent to } 73.6 \text { percent } \\
(-4.7 \text { percent to }+9.9 \text { percent })\end{array}$ \\
\hline $\begin{array}{c}\text { High } \\
\text { Recovery } \\
\text { Potential }\end{array}$ & $\begin{array}{c}\text { Increasing by } 9.7 \text { percent, from } \\
61.7 \text { percent to } 71.4 \text { percent } \\
(-1.7 \text { percent to }+20.6 \text { percent })\end{array}$ & $\begin{array}{c}\text { Increasing by } 4.9 \text { percent, from } \\
61.7 \text { percent to } 66.6 \text { percent } \\
(-3.9 \text { percent to }+13.6 \text { percent })\end{array}$ \\
\hline Conflict & $\begin{array}{c}\text { Increasing by } 4.7 \text { percent, from } \\
78.2 \text { percent to } 82.9 \text { percent } \\
(-3.6 \text { percent to }+13.1 \text { percent })\end{array}$ & $\begin{array}{c}\text { Increasing by } 7.9 \text { percent, from } \\
78.2 \text { percent to } 86.1 \text { percent } \\
(+1.4 \text { percent to }+14.9 \text { percent })\end{array}$ \\
\hline
\end{tabular}

Numbers in parentheses are 95 percent confidence interval for estimate of change in probability.

Based on these predicted probabilities, we can say that (for instance) it is possible that outside groups have a substantial advantage over the agency in identifying species at risk. Our estimate for the relationship between petition status and threat level indicates that species that are the subject of a petition are 
4.8 percent more likely to fall in the upper threat-level category. But it is possible that the advantage is much larger-the upper end of our 95 percent confidence interval has petition status resulting in a 14.6 percent higher likelihood of a species falling in the highest threat-level category. For the agency, at best it has a marginal advantage over outside groups in identifying species at risk, with the lower end of the 95 percent confidence interval showing that petition status means a species has 4.9 percent lower chance of falling in the highest threat group. We find similar distributions for our confidence intervals for the other non-statistically significant relationships.

\section{DISCUSSION}

What is perhaps most striking about our analysis is the lack of any major differences between the species listed as a result of petitions or subject to litigation and species listed by the agency on its own. The only statistically significant difference we were able to detect was a finding that listed species that were the subject of litigation were more likely to pose potential conflicts with development projects.

Our results provide little or no support for the hypothesis that FWS is more expert than outside groups in identifying species at risk. They also provide only limited support for the notion that FWS is more sensitive to cost or conflict than outside groups in identifying species that warrant listing.

The first and most important implication of our results is that-contrary to the critique of petitions developed out of the CPSC experience-it does not appear that petitions have led to the listing of substantially different species under the ESA compared to the species the agency itself identified for listing. In other words, it does not appear that petitions have significantly interfered with FWS's agenda-setting in terms of the three characteristics that we analyzed. Litigation appears to have had more impact on agenda-setting, as it appears to have focused more on species that pose a potential conflict with other development projects. ${ }^{162}$ Still, species listed after litigation face levels of threat similar to those not litigated.

The petition literature also emphasized the possibility for the use or abuse of the process by industry or other special interest groups. In the case of endangered species, the groups involved with petitioning are overwhelmingly environmental or scientific organizations that have a primary focus on

162. The impacts of petitions and litigation on FWS agenda-setting of course have to take into account the agency's own responses to petitions and litigation. As we discuss infra notes 199-200 and accompanying text, we do not think those strategic responses change our conclusions significantly. 
species protection. ${ }^{163}$ Nevertheless, that has not resulted in the listing of species that are less deserving of protection under the Act, or even in significant differences in terms of recovery cost or (for petitions) potential conflict with development projects. Based on our results, there is no reason to conclude that widespread use of petitions will necessarily result in diverting an agency fundamentally from a rational or systematic agenda-setting process-even when the process is dominated by one particular viewpoint or "special interest."

In this Part, we try to dig a little deeper into our results. We explore possible explanations for why we found no significant differences between FWS and outside groups in identifying species at risk, and why the only significant difference we found was that species listed after litigation were more likely to pose potential conflicts.

In the end, we conclude that petitions and citizen suits might have much more to contribute to a regulatory program than simply offsetting political pressure or preventing agency capture. These public participation tools might have an important role to play in collecting dispersed or diffuse information to help better inform agency decisionmaking - and therefore might have utility outside of contexts where one is primarily worried about a captured agency.

\section{A. Why No (Relative) Agency Expertise? The Role of Dispersed Knowledge}

There are no or limited differences between FWS and outside groups with respect to their ability to identify species at risk for listing under the ESA. ${ }^{164}$ Indeed, if there are any differences, outside groups might be better at identifying species at risk. Why might that be?

We begin by identifying what appears to be the key factor: the advantage of outside groups in gathering the highly distributed and dispersed information relevant to the identification of species at risk. We then note how the combination of petitions and judicial review creates incentives for outsiders both to develop and contribute that information, and to do so in a way that increases the likelihood of finding key information that might otherwise be overlooked. We conclude by discussing why we think the benefits of petitions and citizen

163. See supra note 111 .

164. It is likely that the agency is in some way responding strategically to petitions and litigation as part of its own intemal processes of considering species for listing. We do not think that this strategic reaction by the agency makes the agency less effective in identifying species at risk. First, as we discuss infra notes 199-200 and accompanying text, petitions have relatively low stakes for the agency and are unlikely to have a major impact on the types of species the agency considers on its own. Second, we do not see why the agency would have an incentive to avoid higher-or lower-threat species in making its own listing decisions, regardless of the existence of litigation or petitions. 
suits outweigh any transaction or administrative costs, and note the implications of our findings for the petition and citizen suit literature on agency expertise.

\section{The Role of Petitions and Citizen Suits in Bringing Dispersed Information to the Agency's Attention}

One possible reason why outside groups are as good as the agency in identifying species at risk might be leaks by agency staff to outside groups about particular species that warrant listing under the Act but that (for whatever reason, including possible political pressure) either have not been identified by the agency as candidates for listing or have languished in the listing process. This option seems unlikely to us, particularly for petitions. Many of those petitions are filed by individuals or small groups that are unlikely to have contacts with agency staff, and many are scientists who plausibly could develop this kind of information on their own. ${ }^{165}$

Perhaps instead, outside groups also have the resources and interest to develop significant expertise on endangered species. Many of the groups that petition FWS to list species, or that litigate over delays for listing species, are environmental groups. ${ }^{166}$ Many of these environmental groups either have staff scientists or work closely with outside scientists as they draft petitions or conduct litigation. ${ }^{167}$ Moreover, many of the petitioners or litigants that are not environmental groups are scientists themselves. ${ }^{168}$ Our analysis provides evidence that scientists outside FWS are bringing substantial expertise to bear on questions of ESA listing decisionmaking, either indirectly through associations with environmental groups or directly through their own activities. Their expertise likely informs not just the outside groups as they submit petitions to the agency - but through the briefs of litigating environmental groups, that expertise also informs courts as they rule on lawsuits over the ESA listing process.

This explanation may be quite important. The relevant expert knowledge for the identification of species at risk is very diffuse and/or very hard

165. See supra note 112. Our conclusion is also informed by prior practice experience for one of us (Biber), and informal conversations with individuals who are frequently involved in filing ESA petitions and litigation.

166. See supra note 111 .

167. For instance, the Center for Biological Diversity has at least three staff members identified as biologists. See Meet the Staff, CTR. FOR BIOLOGICAL DIVERSTTY, http://www.biologicaldiversity.org/about/ staff/index.html (last visited Nov. 10, 2010).

168. See supra note 112 . 
to obtain. ${ }^{169}$ There are at least 200,000 native species present in the United States. ${ }^{170}$ The sheer number of those species-combined with the fact that for many species (for instance, mussels, insects, and non-flowering plants) only a few experts have any information-means that data is both hard to obtain and likely to be dispersed among a significant number of individuals. ${ }^{171}$ Moreover, the information that is gathered about the status of most species is often not published in the scientific literature until it receives some attention, frequently through listing by a government agency like FWS. ${ }^{172}$ Thus, the information about the status of many listed species is obscure, hard to obtain, and dispersed among many individuals.

While agency capture has been a central rationale for petitions and citizen suits, ${ }^{173}$ our study highlights a very different but perhaps even more important reason for such tools. Information is vital to environmental regulation. ${ }^{174}$ Citizen petitions and suits can help gather the greatly dispersed knowledge relevant to an agency's decisionmaking process. ${ }^{175}$ Instead of relying on its own, limited,

169. Environmental information in general tends to be diffuse and costly to collect. See Thompson, supra note 114, at 190 .

170. See Jonathan S. Adams et al., Biodiversity: Ono Precious Heritage, in NATURE CONSERVANCY \& ASS'N FOR BIODIVERSITY INFO., PRECIOUS HERITAGE: THE STATUS OF BIODIVERSITY IN THE UNITED STATES 9 (Bruce A. Stein et al. eds., 2000).

171. See Holly Doremus, Data Gaps in Natural Resource Management: Sniffing for Leaks Along the Information Pipeline, 83 IND. L.J. 407, 418 n.48 (2008) (noting lack of knowledge about basic biology of many species).

172. See Robert L. Fischman \& Vicky J. Meretsky, Endangered Species Information: Access and Control, 41 WASHBURN L.J. 90, 95-96 (2001) (noting that most endangered species and wildlife management research is not conducive to publication in peer-reviewed journals because of flaws in data collection that delay the peer review process, deterring the submission of information, and that peerreviewed literature may not have the right kind of information to guide management decisions). A significant part of the problem is the lack of institutional incentives, in fields such as ecology, for scientists to collect natural history information, basic biological information about species, and other relatively mundane information, rather than pursuing grand new theories. See Paul K. Dayton, The Importance of the Natural Sciences to Conservation, 162 AM. NATURALIST 1, 9, 10-12 (2003); Doremus, supra note 171, at 422-23. The reluctance of scientists to share data before they publish also makes dissemination of information more difficult. Id. at 437; Fischman \& Meretsky, supra, at 90.

173. See, e.g., David R. Hodas, Enforcement of Environmental Law in a Triangular Federal System, 54 MD. L. REV. 1552, 1624 (1995); Richard J. Lazarus, The Tragedy of Distrust in the Implementation of Federal Environmental Law, 54 LAW \& CONTEMP. PROBS. 311, 315-17, 334 (1991) (connecting citizen suit provisions to congressional fear of agency capture); Stephenson, supra note 117, at 110-12.

174. Bradley Karkkainen has forcefully made this point. See, e.g., Bradley C. Karkkainen, Bottlenecks and Baselines: Tackling Information Deficits in Environmental Regulation, 86 TEX. L. REV. 1409 passim (2008).

175. See, e.g., JOSEPH L. SAX, DeFENDING THE ENVIRONMENT: A STRATEGY FOR CITIZEN ACTION 57 (1971) (noting that citizen suits allow the "possibility that the ordinary citizen may have useful ideas to contribute to the effectuation of the public interest"); Catherine R. Albiston \& Laura Beth Nielsen, The Procedural Attack on Civil Rights: The Empirical Reality of Buckhannon for the Private Attomey General, 54 UCLA L. REV. 1, 8-9 (2007); William B. Rubenstein, On What a "Private Attomey General" Is-And Why It Matters, 57 VAND. L. REV. 2129, $2152 \mathrm{n} .88$ (2004); Stephenson, supra note 117, at 
information-gathering abilities, an agency can seek outside help through requests for information from the broader public. ${ }^{176}$ In order to encourage outside parties to invest the time and energy into collecting the information, Congress or the agency might want to make a credible commitment to use that information as long as it is relevant and accurate. In the context of the ESA, the statutory deadlines plus judicial review through the citizen suit process provide a credible commitment by Congress that FWS will use information submitted through petitions as appropriate, providing sufficient incentives for outside groups to develop this information in petitions. ${ }^{177}$ Thus, citizen suits are in the

107-10. But see John C. Coffee, Jr., Rescuing the Private Attomey General: Why the Model of the Lawyer as Bounty Hunter Is Not Working, 42 MD. L. REV. 215, 221-23, 234 (1983) (arguing that private parties do not have an improved ability to discover violations of the law compared to government prosecutors). There is some evidence that, at least for enforcement purposes, the drafters of the ESA had this rationale in mind as well. House Endangered Species Hearings, supra note 43, at 304 (statement of Thomas Garrett, Wildlife Director, Friends of the Earth) ("[T] here are a lot of people interested in endangered species who live in the areas where endangered species persist who know what is going on, and who would be likely to observe some kind of infringement"); id. at 305 (asking Mr. Garrett to draft appropriate language to insert into the statute).

This rationale has echoes in the calls for the broader use of public participation in environmental decisionmaking in order to incorporate non-expert, local knowledge, such as "popular epidemiology." See FRANK FISCHER, CITIZENS, EXPERTS, AND THE ENVIRONMENT: THE POLITICS OF LOCAL KNOWLEDGE, at xii, 147-69 (2000) (arguing that the public can provide "local knowledge" that can improve environmental decisionmaking); Phil Brown, Popular Epidemiology: Community Response to Toxic Waste-Induced Disease in Wobum, Massachusetts, 12 SCI., TECH. \& HUM. VALUES 78, 78 (1987); Daniel J. Fiorino, Citizen Participation and Environmental Risk: A Survey of Institutional Mechanisms, 15 SCI., TeCH. \& HUM. VAlues 226, 227, 239-40 (1990); Frank Fischer, Citizen Participation and the Democratization of Policy Expertise: From Theoretical Inquiry to Practical Cases, 26 POL'Y SCI. 165, 17881 (1993).

176. The information that a petition provides may be data that has been personally collected by the petition writers. See, e.g., Timothy Allan Watts \& Douglas Harold Watts, Petition to List the American Eel as an Endangered Species Pursuant to the United States Endangered Species Act 16 U.S.C. \$§ 15311544, TAUNTON RIVER J. (Nov. 12, 2004), http://www.glooskapandthefrog.org/ESA\%20petition.htm (providing detailed observations of impacts of hydroelectric turbines on migrating eels). However, many petitions may instead collect published and unpublished reports from academics, government agencies, and conservation organizations. See, e.g., CTR. FOR BIOLOGICAL DIVERSITY, PETITION TO LIST 83 CORAL SPECIES UNDER THE ENDANGERED SPECIES ACT 132-45 (2009), available at http://www.biolog icaldiversity.org/species/invertebrates/staghorn_coral/pdfs/Coral\%20petition_10-20-09.pdf (compiling literature on the status of coral reefs and threats they face, including climate change and ocean acidification). Compilation of these kinds of reports can be equally important for a government agency, given the difficulty of tracking down the relevant literature (particularly reports not available in peer-reviewed journals). These types of petitions serve a role similar to that played by review articles in peerreviewed journals that compile and synthesize the relevant literature, a role useful even for those expert in the field.

177. This establishment of a nongovernmental network of environmental expertise is an example of what Barton Thompson has called the "citizen monitor" movement that has arisen in environmental law, where environmental groups conduct monitoring and other data-gathering activities to produce important information about environmental quality and violations that might otherwise be missed by overstretched government agencies. See Thompson, supra note 114, at 216-26; see also Douglas A. Kysar \& James Salzman, Foreword: Making Sense of Information for Environmental Protection, 86 TEX. L. REV. 
end as important as petitions to the story of how the ESA gathers dispersed information to make listing decisions.

We don't want to overemphasize the dichotomy between the capture and information-gathering rationales for citizen participation. One aspect of traditional agency capture theory is that agencies are captured by regulated parties in part because those regulated parties control so much of the information that agencies need to regulate. ${ }^{178}$ Reciprocally, without reliable public information as to which species might be at risk, a captured agency will have a much easier time claiming that it has protected all the species that warrant protection, even when that in fact is not the case.

While there has been some recognition that public participation mechanisms such as petitions and citizen suits can be an important source of information for environmental regulation, ${ }^{179}$ some scholars have been skeptical about whether citizen suits really do result in the production of new information, leading to claims that petitions or citizen suits will improperly skew the agency's agenda-setting. ${ }^{180}$ We think that, given our results, that skepticism has been overblown. To the contrary, petitions and citizen suits can bring more information to the agency, helping the agency do its job of accomplishing the task Congress set out in the ESA: identifying and listing the species that are at risk.

\section{Drawing on a Diverse Range of Public Participants to Maximize Information Production}

By aggregating information from a large and diverse body of citizens, public participation in the administrative process might help overcome the limitations of relying on a relatively small number of experts within the agency to identify species at risk. There is some evidence from the social science literature that individual experts might face challenges in making predictions based

1347,1353 (2008) (noting that the role of civil society in gathering information is an important, unresolved question in environmental law); Christine Overdevest \& Brian Mayer, Hamessing the Power of Information Through Community Monitoring: Insights From Social Science, 86 TEX. L. REV. 1493, 150910 (2008) (describing similar programs).

178. See, e.g., JOHN E. CHUBB, INTEREST GROUPS AND THE BUREAUCRACY: THE POLITICS OF ENERGY 158-167 (1983); WESLEY A. MAGAT ET AL., RULES IN THE MAKING: A STATISTICAL ANALYSIS OF REGULATORY AGENCY BEHAVIOR 71-72 (1986).

179. See, e.g., Adler, supra note 116, at 43 (conceding that in theory citizen suits can result in the production of useful information); Schwartz, supra note 30, at 54 (noting the role that petitions have played in alerting CPSC to new risks); supra note 175.

180. See Greve, supra note 116, at 371-72 (1990) (claiming that citizen suits to enforce Clean Water Act permit provisions against industry do not produce any new environmental information but instead rely solely on reviewing emissions data that is already publicly available). 
on uncertain and diffuse information. ${ }^{181}$ There is even literature specific to conservation biology that questions the ability of individual experts to make informed guesses about the future of species at risk. ${ }^{182}$

In response, various scholars and commentators have emphasized the advantage of relatively large groups in collecting diffuse information and making forecasts in areas as diverse as solving puzzles, betting on sporting events, predicting the outcome of elections, and even predicting the outcome of Hollywood award ceremonies. ${ }^{183}$ This advantage is accentuated if the individuals' choices and participation are relatively independent of each other and if their viewpoints or knowledge are relatively diverse. ${ }^{184}$

All of these features are present to some extent in the petition and citizen suit processes. Because any person can submit a petition, ${ }^{185}$ and a wide range of

181. See, e.g., CASS R. SUNSTEIN, INFOTOPIA: HOW MANY MINDS PRODUCE KNOWLEDGE 2143 (2006); JAMES SUROWIECKI, THE WISDOM OF CROWDS 3-22 (2004); Robyn M. Dawes et al., Clinical Versus Actuarial Judgment, 243 SCIENCE 1668, 1671 (1989); Werner F. M. De Bondt \& Richard H. Thaler, Do Security Analysts Overreact?, 80 AM. ECON. REV. 52, 52 (1990); John C. Easterwood \& Stacey R. Nutt, Inefficiency in Analysts' Earmings Forecasts: Systematic Misreaction or Systematic Optimism?, 54 J. FIN. 1777, 1779-80 (1999); James Shanteau et al., How Can You Tell If Someone Is an Expert? Performance-Based Assessment of Expertise, in EMERGING PERSPECTIVES ON JUDGMENT AND DECISION RESEARCH 620, 622-27 (Sandra L. Schneider \& James Shanteau eds., 2003); Thomas R. Stewart, Improving Reliability of Judgmental Forecasts, in PRINCIPLES OF FORECASTING: A HANDBOOK FOR RESEARCHERS AND PRACTTTIONERS 81, 87-88 (J. Scott Armstrong ed., 2001); Willem A. Wagenaar \& Gideon B. Keren, Calibration of Probability Assessments by Professional Blackjack Dealers, Statistical Experts, and Lay People, 36 ORGANIZATIONAL BEHAV. \& HuM. DECISION PROCESSES 406, 407-08 (1985).

182. Michael A. McCarthy et al., Comparing Predictions of Extinction Risk Using Models and Subjective Judgement, 26 ACTA OECOLOGICA 67, 72 (2004) (finding that models are less biased than expert subjective judgments in making predictions about risks of population declines for species).

183. See, e.g., SUNSTEIN, supra note 181; SUROWIECKI, supra note 181; J. Scott Armstrong, Combining Forecasts, in PRINCIPLES OF FORECASTING, supra note 181, at 417, 427-33 (surveying literature that shows that combining multiple expert forecasts often results in better forecasts than individual expert forecasts); Raymond D. Sauer, The Economics of Wagering Markets, 36 J. ECON. LIT. 2021, 2044 (1998) ("It is clear that trading in these markets creates measures of the probability of winning which are significantly better than measures produced by an individual or group of experts.").

184. See SUROWIECKI, supra note 181, at 23-65. Independence is important because otherwise, subsequent decisionmakers may decide to ignore their own sources of information and instead follow the decisions made by earlier decisionmakers. The result is an "informational cascade" in which diffuse information might be ignored. Id. at 63-65; see also Sushil Bikhchandani et al., A Theory of Fads, Fashion, Custom, and Cultural Change as Informational Cascades, 100 J. POL. ECON. 992, 994 (1992) (providing a formal model of the problem).

Diversity is important because the greater range of viewpoints, perspectives, and information, the more likely it is that diffuse sources of information will be identified, collected, and used. See SUROWIECKI, supra note 181, at 23-39; Armstrong, supra note 183, at 417, 419,425-26; Lu Hong \& Scott E. Page, Problem Solving by Heterogeneous Agents, 97 J. ECON. THEORY 123, 130-31 (2001); James G. March, Exploration and Exploitation in Organizational Learning, 2 ORG. SCI. 71, 76-79 (1991).

185. 16 U.S.C. $\$ 1533$ (b)(3)(A) (2006) (referring to 5 U.S.C. $\$ 553$ (e), the petition provision of the APA, as the basis for petitions to list species); 5 U.S.C. $\$ 553(\mathrm{e})$ (2006) (allowing any "interested person" to file a petition to issue, amend, or repeal a rule). 
parties can file suit to challenge agency decisions, ${ }^{186}$ both the petition and citizen suit processes encourage participation by a maximal number of people who will collect as much diffuse information as possible about species at risk. The composition of the parties that might potentially submit petitions or file citizen suits is likely more diverse than the scientists and officials that staff FWS, who, after all, are part of a larger organization that undoubtedly exerts some homogenizing influence in terms of acculturation and training. ${ }^{187}$ As for independence, there is no legal requirement that petitions must precede the identification of species at risk by the agency or vice versa, and thus the filing of a petition (at least in theory) might happen regardless of the agency's own deliberations. ${ }^{188}$ Nor does the filing of a petition and rejection of it (or stalling) by the agency preclude the filing of a new petition by another group in the future. ${ }^{189}$ Thus, in compiling the aggregate list of species worthy of protection, a wide range of sources decreases the risk that worthy individual species will be ignored.

\section{Are Petitions and Citizen Suits Worth It?}

Petitions and litigation, however, necessarily involve transaction and litigation costs. If they result in decisions that are no different from those the agency would have reached anyway, are they worth it?

186. 16 U.S.C. $\$ 1540(\mathrm{~g})(1)$ (authorizing "any person" to file citizen suits).

187. See HERBERT KAUfMAN, THE FOREST RANGER: A STUDY IN ADMINISTRATIVE BEHAVIOR 190-93 (1960) (describing how the U.S. Forest Service acculturated its employees); HERBERT A. SIMON, ADMINISTRATIVE BEHAVIOR: A STUDY OF DECISION-MAKING PROCESSES IN ADMINISTRATIVE ORGANIZATION, at xvi (3d ed. 1976) ("A man does not live for months or years in a particular position in an organization, exposed to some streams of communication, shielded from others, without the most profound effects upon what he knows, believes, attends to, hopes, wishes, emphasizes, fears, and proposes."); id. at 198-220 (discussing loyalties to organizations and organizational identities); Eric Biber, Too Many Things to Do: How to Deal With the Dysfunctions of Multiple-Goal Agencies, 33 HARV. ENVTL. L. REV. 1, 35-41 (2009) (noting the importance of agency culture in determining agencies' ability to develop better ways to obtain information); March, supra note 184, at 74 ("An organization socializes recruits to the languages, beliefs, and practices that comprise the organizational code.").

188. We say in theory because it is possible that despite the legal ability of an outside group to file a petition after the agency has already listed a species as a candidate or refused to list a species, groups may be discouraged from petitioning by this prior agency activity. There are examples of petitions being filed in these siruations, but there is no systematic evidence of whether in practice petitions are more or less likely to be filed.

189. For example, two peritions were filed in 1986 and 1987 to list the Northern Spotted Owl, three petitions were filed in 1992, 1995, and 1997 to list the Barton Springs Salamander, and two petitions were filed in 1992 and 1998 to list the Alabama Sturgeon. Again, there is no systematic data on whether petitions are more or less likely after a species has been rejected by the agency for listing, or after the agency has sat on a proposal to list for an extended period of time. 
We have a number of responses. With respect to petitions, the transaction costs appear to be minimal, as they involve the compilation of relevant biological data (which the agency would do in any case when considering on its own whether to list a species), the drafting and mailing of a petition to the agency, and the burden on the agency to receive the petition and keep track of the petition. ${ }^{190}$ Moreover, it is possible that deserving petitioned species would otherwise have escaped the agency's attention and failed to be protected. ${ }^{191}$ The argument against petitions based on transaction costs must then be that the minimal transaction costs of petitions outweigh the benefit of identifying species that are deserving of listing and would otherwise go without protection under the Act. We think that is highly unlikely.

With respect to litigation, it is clear that the costs of the process are much more significant-lawsuits are costly. But the benefits here also appear large. Based on the correlation between litigation status and potential for conflict, it seems clear that litigation is resulting in the listing of at least some species that pose a greater risk of conflict, economic and most likely political as well. Because, in many ways, a "captured" agency is the flipside of an agency that is avoiding tunnel vision, one might say that the litigation process is restricting the ability of a captured agency that is balancing costs and benefits of species listings to not list certain controversial species (contrary to the statute). ${ }^{192}$ In other words, litigation is leading to the listing of species that are inconvenient politically, but are otherwise deserving of protection under the Act. ${ }^{193}$ Given Congress's stated goals in the ESA listing provision of protecting species regardless of economic cost, that seems to be a strong benefit - again, with no cost in terms of technical expertise- that might outweigh the transaction costs of litigation.

190. Of course, there may be an opportunity cost of species the agency cannot consider on its own because of resources devoted to responding to petitions. But each petitioned species is on average at least as meritorious for listing as non-petitioned species. Thus, whether a peritioned species would replace the agency's consideration of a non-petitioned species is not a cost to the system.

191. The hypothetical that we cannot answer is what agency-initiated species would have replaced the petitioned species in the listing process. We do not know whether those hypothetical agency-initiated species would have been as worthy of listing.

192. We discuss this point in more detail at note 200 , infra, and accompanying text.

193. We do note that our political control variables generally did not show any statistically significant relationship with threat level, cost, or conflict. We have a few thoughts as to how to reconcile these results with our finding that the agency is more reluctant to list species that pose a risk of conflict with development projects: (1) the agency itself may be institutionally averse to listing species that pose a risk of conflict, regardless of the political environment in the White House or Congress (perhaps because the agency wishes to avoid conflicts with other government agencies); (2) the political pressure to avoid listing "inconvenient" species is bipartisan, such that our measures of League of Conservation Voters (LCV) scores and party affiliation of the president are irrelevant; or (3) the political pressure predominantly issues from the House, not from the president or the Senate. 
The importance of litigation is highlighted by the political context for ESA listing decisions. There is no question that listing decisions under the Act have been the focus of a great deal of political controversy, and there are a number of commentators who have argued that FWS has responded to that controversy by avoiding the listing of species that pose significant economic and political costs to the agency ${ }^{194}$ Such avoidance is possible, in part, because the number of species that are likely eligible for listing under the Act far exceeds the capacity of FWS to list in any given year-resulting in a tremendous backlog of species warranting listing. ${ }^{195}$ The litigation process (and to a lesser extent, the petition process) prevents FWS from selecting only the politically favored species among those that warrant listing, a selection process that would run counter to Congress's instructions to ignore politics and economics in ESA listing decisions.

More broadly, for both petitions and litigation there may be a wide range of other benefits from public participation besides technical expertise, including obtaining public acquiescence or support for administrative regulatory decisions, or meeting requirements of due process. ${ }^{196}$ Again, our results indicate that there need not be any "cost" in terms of technical expertise in achieving these other benefits through broader public participation.

In fact, as we noted in Part $\mathrm{O}$, for both petitions and litigation, our results indicate that if there is any difference between the agencies and outside groups, the differences cut in favor of outside group expertise. The coefficients, while statistically insignificant, all indicate that outside groups are better at identifying species at risk. Thus, it seems possible that the public participation process is actively improving the decisionmaking process on technical terms alone.

194. See, e.g., Holly Doremus, Adaptive Management, the Endangered Species Act, and the Institutional Challenges of "New Age" Environmental Protection, 41 WASHBURN L.J. 50, $58-59$ (2001) (noting agency efforts to avoid controversy in implementation of the ESA).

195. See Endangered and Threatened Wildlife and Plants: Review of Native Species That Are Candidates for Listing as Endangered or Threatened, 73 Fed. Reg. 75,176, 75,177, 75,185-86 (Dec. 10,2008 ) (codified at 50 C.F.R. $\S 17(2010)$ ) (stating that only about forty species of a total of 251 candidate species would be listed in 2009 because of funding constraints); see also Daniel J. Rohlf, Section 4 of the Endangered Species Act: Top Ten Issues for the Next Thirty Years, 34 ENVTL. L. 483, 493-96 (2004) (describing how there has always been a large gap between the number of species that warrant listing and FWS's ability to list those species); infra notes 225-228 and accompanying text. We add that the large number of species eligible for listing under the ESA should not be interpreted as undercutting the challenge of identifying which species are in fact eligible. Even the large number of species that are currently listed as candidates for listing are a fraction of the total number of species in North America. See supra note 170 and accompanying text.

196. See, e.g., Daniel J. Fiorino, Citizen Paticipation and Envinommental Risk: A Survey of Institutional Mechanisms, 15 SCI., TECH. \& HUM. VALUES 226, 227-28 (1990) (laying out the benefits from public participation in decisionmaking). 
In short, we think that public participation through petitions and litigation is, at the very least, resulting in technical decisions that are as good as the agency would produce itself, with additional benefits in terms of listing species that might be excluded because of political pressure. We also conclude that, in the context of ESA listing decisions, those benefits are worth any litigation and transaction costs. ${ }^{197}$

\section{B. Digging Into the Tunnel Vision Theory}

What do our results have to say about the tunnel vision theory? Our original hypothesis was that FWS was not a tunnel vision agency (at least compared to outside groups) - in other words, FWS would be more sensitive to cost and conflict than outside groups, but would also be more effective at identifying species at risk.

At first blush, our results do not provide much support for our original hypothesis. We did not find a substantial difference between FWS and outside groups on any factor except for one: Compared to listed species that had been the subject of litigation, FWS was more sensitive to the possibility of conflict with other development projects. Otherwise it seems that FWS is just as indifferent to cost or conflict as outside groups.

One answer may be that no one, including FWS, is very good at identifying features such as high cost up front-for instance, it may be very difficult for either an outside group or FWS to identify ex ante species that are low cost, until and unless significant resources are invested to actually determine why a species is threatened, what the seriousness and nature of the threat is, and so forth. That investment of resources may not occur until after the species is listed (or at least until a significant time after the species has been initially identified as potentially warranting listing). Likewise, it may be difficult to determine

197. There is also a question of how the agency might act if there were no petition and citizen suit provisions, a point we discuss infra at notes 199-201.

What role do agencies play if they are not necessarily experts compared to the public? A potential answer is that agencies serve to audit the information, ensuring that it meets minimum standards of quality (that is, that a petitioned species warrants listing) so that it can be used as the basis for listing decisions. See Benkler, supra note 11, at 390-96 (noting importance of accreditation of information quality for distributed information production). For instance, not all petitions will be of equally high quality; thus, FWS serves a role of auditing petitions and making evaluations about the quality of information in them.

Beyond auditing, other possible value-added roles for FWS include additional diversity of opinion, resources, and institutional context. Even if FWS isn't any better than outside groups overall in its ability to identify species at risk, it nonetheless adds an important institutional perspective that might not be present among those outside groups, including connections with other government agencies, access to information that only the government might have, resources that are much larger than any one of the individual outside groups, and institutional continuity and knowledge that few organizations besides a long-lived government agency can have. 
whether conservation of a species will conflict with development, until and unless the nature of threats is better understood, which again may not happen until after the species is listed, or at least until after the species has received a significant amount of focus from FWS and other conservation organizations.

This delay in developing information about species may well be why we only found a statistically significant relationship between litigation and conflict. Litigation generally will happen a significant time after a species has been initially identified as possibly warranting listing through a petition or by the agency. Indeed, most of the litigation in ESA cases involves litigation over agency delays in listing species. ${ }^{198}$ Thus, by the time litigation occurs, there may be more information available as to whether the species concerned poses a conflict with development projects.

Moreover, compared to the direct cost of recovering listed species, it may be easier and quicker for officials in the White House, Congress, or the agency to identify when conflict might occur between a species being considered for listing and future development projects. After all, it is not that difficult to predict that listing a fish species that lives in a free-flowing river will likely result in conflict with proposals to build a dam across that river. In fact, litigation might be happening precisely because FWS is dragging its heels in completing the listing process after becoming aware of a potentially significant conflict between the species and other projects.

Another factor that might lead to the greater gap, in terms of conflict potential, between litigated and non-litigated species than between petitioned and non-petitioned species is strategic behavior by the agency in response to the existence of petitions and litigation. That is, there may be a significant difference in terms of how the agency responds to petitions as compared to litigation.

First, consider petitions. Petitions impose a relatively small cost on the agency and can be resolved with relatively low stakes for the agency's regulatory programs. The cost of processing petitions, as discussed earlier, may not be much of an additional burden on the agency. FWS can also deal with petitions in a way that minimizes the stakes for the agency. It can choose to reject them (with the potential cost of litigation over the denial lessened by generally deferential judicial review), or it can place the species in the "warranted but precluded" category, ${ }^{199}$ which is unlikely to provoke litigation (and in any case would be extremely hard to challenge using litigation). The "warranted but precluded" category results in almost no regulatory impacts on FWS, private

198. See supra note 151.

199. See supra note 63. 
parties, or other government agencies. In other words, there is little reason for FWS to act in a way to avoid petitions being submitted, or to avoid studying species that might or might not be subject to petitions. The stakes at the petition stage - given the existence of the "warranted but precluded" safety valve-are lower for the agency.

Litigation, on the other hand, is much more costly to the agency and has much higher stakes for the regulatory program. First, it is costly for the agency to be involved in litigation, and second, a loss in litigation can result in being forced to list the species, a non-trivial expenditure out of the agency's listing budget. ${ }^{200}$ Moreover, the listing of a species triggers significant regulatory impacts (as opposed to "warranted but precluded" status). On the one hand, the agency's desire to avoid litigation might lead it to aggressively list a wide range of species to preempt lawsuits. However, that could be offset by the regulatory impacts of listing a species that might impose high economic and political costs-leading the agency to avoid listing species that pose conflicts to the extent possible, and only listing those species when forced to do so by litigation. Our data showing a statistically significant gap between litigated and non-litigated species indicates that the latter factor might be winning out. If so, that would mean that without litigation, FWS might list even fewer species that pose a potential for conflict with development.

Whether the explanation is based on the lack of information or on agency strategic behavior, FWS appears to be relatively sensitive to the possibility of conflict with development projects in its management of the ESA listing program, at least compared to outside groups. ${ }^{201}$ Of course, the baseline by which we are measuring agency performance here is relatively low, in that one might expect the environmental groups that dominate the petition process to be relatively indifferent to the possibility of conflict. Nonetheless, the agency is still apparently taking into account, to some extent, at least the possibility of conflict in managing the ESA listing program-despite an absolute prohibition in the statute against considering this factor in listing species, and in the face of fairly constant petitioning, litigation, and monitoring by environmental groups.

200. See Endangered and Threatened Wildlife and Plants: Review of Native Species That Are Candidates for Listing as Endangered or Threatened, 73 Fed. Reg. 75,176, 75,185 (Dec. 10, 2008) (codified at 50 C.F.R. $\$ 17(2010)$ ) (discussing that the cost of preparing a listing rule for a species proposed for listing has ranged from $\$ 11,000$ to $\$ 305,000$ ).

201. It seems plausible to us that the lack-of-information explanation has more bearing on the recovery cost factor, and the strategic-behavior explanation has more bearing on the conflict-with-development factor. 
We return to our original question: What impacts do petitions and citizen suits have on the possibility of tunnel vision behavior by FWS? Our conclusions are necessarily limited because of the lack of data for the counterfactual of how FWS would act without petitions or citizen suits, but we think that they are at least illuminating. Even though the statute prohibits consideration of cost, with the frequent use of litigation and petitions to enforce that prohibition, and without significant oversight from OMB, FWS still does take into account the potential for conflict at least some of the time. At the least, we can say that broad public participation by outside groups in environmental regulation will not necessarily result in an extreme tunnel vision agency. Indeed, we wonder how much other environmental agencies with less strict statutory mandates, less frequent environmental group involvement in the administrative and judicial process, and more OMB review of their work, are weighing cost in their work.

Accordingly, these results raise questions about the claim that public participation contributes to irrational decisionmaking on the part of environmental agencies. However, we have to note an important distinction here between two different kinds of possible irrationalities in agency decisionmaking: benefits versus costs. On the one hand, public participation might undermine the agency's ability to identify the benefits of regulation-in this case the threats faced by species being considered for listing, threats that might be ameliorated by listing protection. Our results indicate that public participation does not lead the agency to significantly different conclusions from outside groups about which species are most at risk, and that therefore public participation is not inconsistent with rational decisionmaking in that context. ${ }^{202}$ On the other hand, public participation might undermine the agency's ability to adequately assess the costs of regulation-such as recovery costs or conflict with development projects. Here, our results are more ambiguous. Litigation does focus on species that are more likely to present conflict with development-and in that way, forces the regulatory program to bear more costs. But in its sua sponte decisions, the agency is still taking regulatory cost and interagency conflict into account, at least to some extent, even in a legal environment that prohibits the consideration of cost and impacts on other social

202. Our analysis, of course, only provides a relative comparison of agency performance with outside group performance, and can't give insight as to whether the agency is also acting irrationally in setting its agenda for listing species. Many of the critics have accused not just the public, but the regulatory agencies, of irrational agenda-setting. See supra note 91 . While it is not definitive, we do have some limited data that indicates that FWS's agenda-setting based on threats to listed species is not irrational: FWS's assessment of the threats facing species that are listed correlates extremely well with expert assessment of those threats from outside the government. See App., infra, tbl.8. 
goals, and where FWS faces regular petitions and litigation over its listing decisions from environmental groups. Certainly, even for cost, we do not have results that show that public participation will eliminate "rationality" on the part of the agency.

Our analysis also raises questions about the role of regulatory review in fighting tunnel vision. For the cost of recovering species, our results showed little difference between outside groups and FWS, perhaps because of the dearth of information on both recovery cost and potential conflict. If information about cost is hard or even impossible to collect while agencies are developing their agendas, then regulatory review based on cost will simply be impossible. It seems unlikely to us that this problem is limited to just endangered species-other scholars have noted the limits that information can pose to the project of cost-benefit analysis and regulatory review. ${ }^{203}$ Absent this information, efforts at regulatory review run the risk of sliding into results-oriented analysis that is dominated by the ideology or professional perspective of those performing the review. ${ }^{204}$ Given the lack of data about cost and conflict at the petition or even litigation stage, the ESA prohibition on the consideration of economic impacts in making listing decisions makes sense as a way to avoid precisely this problem. ${ }^{205}$ With the political pressures that the Act already faces, it is quite possible that in the absence of cost or conflict data, any cost-benefit analysis would result in the foregone conclusion that preservation of most (all?) species is outweighed by the economic costs. The lack of data would, in other words, end up becoming a cover for the politically expedient result of avoiding listing species that might pose a problem in the future.

\section{CONCLUSION: BROADER IMPLICATIONS FOR ENVIRONMENTAL AND ADMINISTRATIVE LAW}

Our central conclusion is simple. In the implementation of a significant part of one of the most important environmental laws in the United States-the program for listing species for protection under the ESA — there is no evidence of any substantial difference between the ability of FWS as the implementing

203. See Douglas A. Kysar \& Thomas O. McGarity, Did NEPA Droun New Orleans? The Levees, the Blame Game, and the Hazards of Hindsight, 56 DUKE L.J. 179, 227-31 (2006).

204. See id. at 211-12 ("[A]s one moves farther away from the available data ... the risk increases that one's conclusions will be based on undefended modeling assumptions rather than on actual empirical evidence.").

205. Accordingly, our results undercut arguments for prioritizing endangered species protection on the basis of cost, at least at the listing stage. See supra note 104. 
agency and outside groups to identify species that warrant listing under the Act. Criticisms of either petitions or citizen suits as necessarily causing uninformed decisionmaking, interfering with agency priority-setting, undermining agency expertise, or leading to overenforcement against low-value targets are wrong. Indeed, there is some evidence from our study that petitions and citizen suits might lead to better-informed decisionmaking. In other words, in the right circumstances, economists, engineers, biologists, and other technical experts might welcome public participation, not just because it might increase public acceptance of final agency decisions, but also because the public might help the agency reach better decisions in the first place. ${ }^{206}$ Outside groups can contribute meaningfully to agenda-setting in a productive and rational way.

We conclude by exploring two of the implications of our findings. First, why do petitions work in the context of the ESA but not in the context of the CPSC, and how might that explanation help us identify other areas where petitions might improve environmental policymaking? Second, if petitions and citizen suits do not necessarily conflict with thoughtful, expert, or rational agency priority-setting, how might courts, legislators, or legal scholars want to reconsider their approaches towards petitions and citizen suits (or public participation more broadly) in environmental law specifically and administrative law more generally?

\section{A. Identifying Other Areas Where Petitions Might Improve Environmental Policymaking}

We might want to consider the broader use of petitions and citizen suits in environmental law, not just in the areas where we think the agency might be subject to capture by regulated interests, but more generally where there is dispersed information that could lead to better decisionmaking. On the other hand, there is the counterexample from the CPSC. What went wrong with the CPSC and what has gone right in the ESA context? In other words, what might be the right circumstances for the broad use of petitions and citizen suits?

First, it is important to keep in mind that the listing process in the ESA is a relatively narrow range of decisions that involve a relatively narrow range

206. The literature on "new governance" and collaborative regulation has touched on this point. See, e.g., Alejandro E. Camacho, Can Regulation Evolve? Lessons From a Study in Maladaptive Management, 55 UCLA L REv. 293, 318-19 (2007); Michael C. Dorf \& Charles F. Sabel, A Constitution of Democratic Experimentalism, 98 COLUM. L. REV. 267, 267-68 (1998); Jody Freeman, Collaborative Governance in the Administrative State, 45 UCLA L. REV. 1, 22-23 (1997); Orly Lobel, The Renew Deal: The Fall of Regulation and the Rise of Governance in Contemporary Legal Thought, 89 MINN. L. REV. 342, 373-76, 425-27 (2004). 
of factors. In making listing decisions, the agency is legally required to consider only a set of technical factors about the degree of threat faced by the species. Listing decisions are in turn a set of discrete decisions that involve relatively limited tradeoffs in terms of resource allocation. This is, in part, because the agency is only making one type of decision (whether to list or not), not a range of different decisions (which items to regulate, which forms of regulatory tools to use for each item, how stringently to regulate using particular tools, and so forth). This is also because of the isolation of FWS's listing budget from the rest of its budget-itself a product of the litigation over listing (at least that is the explicit rationale the agency used to justify the cap on listing expenditures) ${ }^{207}$ To summarize, petitions and citizen suits may lead to better technical decisions without interfering with agency agenda-setting for an agency that is (a) making a relatively simple set of decisions (b) using technical factors that do not require complicated resource trade-offs with a range of other activities. ${ }^{208}$

To emphasize the point, as noted earlier, our study most clearly shows the benefits of the use of petitions to help agencies develop technical information about the benefits of regulation-in this case, the threats faced by species that might be listed for protection under the ESA. That is one form of rationality in the context of the environmental law literature. However, we can say much less about whether petitions would work sensibly in a regulatory program where either (a) cost was a significant and legal consideration for the agency to take into account (unlike the ESA, but like decisionmaking under the Toxic Substances Control Act)-another form of rationality in environmental law; or (b) the decisionmaking process requires trade-offs among a range of amorphous and unspecified public values, only some of which might involve technical considerations (such as Federal Communications Commission regulation in the "public interest"). The latter situation in fact resembles what most agencies must do when they decide how to allocate their budget across a range of programs and priorities-a situation not present for the ESA listing budget.

The criteria for successful use of petitions might seem to delimit a relatively narrow universe. And yet, there is a wealth of examples of decisions in environmental law that might at least partially satisfy these criteria: the identification of waterways that are impaired because of stormwater pollution; ${ }^{209}$

207. See supra note 74 .

208. We add that we are limiting our conclusions in this way not because we have found positive evidence that petitions or citizen suits are problematic in orher circumstances but simply because our data do not extend that far.

209. See, e.g., 33 U.S.C. $\$ 1342$ (p) (2006) (providing for the identification of watersheds that are impaired as a result of stormwater runoff and for the imposition of additional permitting requirements); 
identification of roads, trails, or lands that are being significantly impacted by off-road vehicle use; $;^{210}$ or the identification of pesticides that might pose health or ecological risks and therefore warrant review of their regulatory approval, ${ }^{211}$ among others. All of these decisions at least initially involve the application of technical analysis to make decisions on a limited set of factors, usually the level of environmental harm or damage that might be at stake. (While cost or other values might be relevant at the aggregate level for these decisions, or in deciding what to do once particular threats are identified, they are much less relevant in the identification of individual cases for agency consideration.)

One reason why these types of regulatory decisions might be appropriate for petitions is that they are all what Yochai Benkler calls both "modular" and "granular." 212 ESA listing decisions are modular in that the ESA regulatory program can (in relevant part) be broken into individual decisions about the listing of particular species-there is no necessary legal connection between the listing of one species and the listing of another. Listing decisions are granular in that they rely on a limited set of technical factors and therefore are relatively cheap, easy tasks to perform (compared to other regulatory decisions) - petitioners need only collect biological data to submit a petition, rather than information about (for example) the potential regulatory impacts of listing a species. Both modularity and granularity, as Benkler points out, allow the division of a large task (here the development of a list of all species that warrant protection under the ESA) into individual parts that can be performed by a large number of individuals - and thus are possible reasons why the ESA listing process has been able to successfully take advantage of the contributions of a wide range of outside groups.

There is another way in which the ESA listing process reduces the upfront cost of listing decisions for the agency. For ESA listing decisions, there is a relatively straightforward default legal regime that applies to items that are identified through the regulatory process. Species that are listed under the ESA receive a

40 C.F.R. $\& 122.26(f)(2)$ (2010) (implementing regulation allowing for petitions to designate watersheds under this statutory provision); Dave Owen, Urbamization, Water Quality, and the Regulated Landscape, 82 COLO. L. REV. (forthcoming 2011) (describing this program under the Clean Water Act).

210. See, e.g., 43 C.F.R. $\$ 8341.2$ (2010) (requiring the Bureau of Land Management to close areas to off-road vehicle use when adverse impacts to resources are occurring).

211. See, e.g., 7 U.S.C. $\$ 136 \mathrm{~d}(\mathrm{~b})$ (2006) (allowing for cancellation of registration of pesticides where adverse health or environmental effects are discovered); see also Wendy Wagner, Using CompetitionBased Regulation to Bridge the Toxics Data Gap, 83 IND. L.J. 629, 644-46 (2008) (proposing the use of the petition process to help identify toxic chemicals that should be regulated because of health risks).

212. Benkler develops these concepts in his discussion of "peer production" on the intemet. See BENKLER, supra note 11, at ch. 4; Benkler, supra note 11, at 390-96. 
certain amount of protection under the Act, absent affirmative steps by the agency to adjust that protection. ${ }^{213}$

In contrast, in the CPSC context, the identification of a product as potentially hazardous through either petition or a citizen suit required the agency to not only regulate, but to develop a specifically tailored regulatory program for the product. ${ }^{214}$ That process itself often required enormous time and effort on the part of the agency. And it was that process that ultimately bogged down the agency and meant that decisions about whether to regulate a particular product were also decisions, in effect, about what the agency would be doing with much of its time for the next several years.

This issue of the administrative burdens that the regulatory process imposes on the agency is one that we did not study in our analysis in the ESA context. It might well be that increasing numbers of petitions or litigation might cause the ESA listing process to crash simply because of sheer numbers. The cap on the budget for listing decisions means that, for now, that risk is reduced. Our intuition is that the default regulatory system in the ESA listing process means it can better handle a high number of listings. In any case, this is an important issue that we can only touch upon here. ${ }^{215}$

Overall, petitions and citizen suits can be effective tools in environmental management, in the right circumstances. Agencies interested in using these tools more might (for instance) use their regulatory authority to create petition processes in order to help identify problems or regulatory needs, even if there is no explicit statutory system in place. ${ }^{216}$ Our advice would be that any such

213. Species listed as endangered automatically receive the full level of protection under the ESA, and FWS has drafted a regulation that gives, as a default matter, threatened species the same level of protection-unless the agency drafts a less protective rule pursuant to 16 U.S.C. $\S 1533$ (d) (2006), which allows FWS to develop lower levels of protection against harm from private parties for species that are listed as threatened. See 50 C.F.R. $\$ 17.31$ (a) (2010).

214. The process was originally even more complicated in that the CPSC was required to work with a private "offeror," who developed the initial draft of the regulatory standard for each product. See Schwartz, supra note 30, at 57-64. "Offerors" frequently required substantial financial support from the agency to develop the proposed standard. Id.

215. It is possible that public participation might lead to the listing of too many species. Without the listing cap, for instance, FWS might be forced to list so many species that it would cause not only a negative impact on the FWS's ability to allocate its budget to other responsibilities but also broader negative impacts for the regulatory program (e.g., political backlash and diminishing benefits from listing). Even with the listing cap, the sheer number of petitions filed might cause the listing process to break down at some point. See Keith W. Rizzardi, Bulk Petitions: Breaking the Endangered Species Act, A Few Hundred Species at a Time?, ESA BLAwG (Aug. 31, 2001), http://www.esablawg.com/esalaw/ESBlawg.nsf/d6plinks/ KRII-88H2VY (arguing, in his capacity as an ESA attorney and commentator, that the surge in the number of petitioned species threatens functioning of the ESA listing and regulatory processes). Our results do not address this issue.

216. EPA has done just this in its stormwater regulatory program. See supra note 209. Agencies may well be interested in setting up such petition processes to the extent that they want help in 
program should: (a) focus on tasks that are relatively simple and cheap to accomplish; (b) result in the imposition of a default regulatory standard to minimize the administrative burden on the agency; (c) allow for some sort of safety valve if the default standard is inappropriate; (d) commit the agency to take action on petitions for which the necessary standard has been met; and (e) impose a cap on the maximum number of petitions that can be granted in a year, in order to keep the petition process from swamping the rest of the agency's regulatory agenda.

\section{B. Reconsidering Judicial and Scholarly Attitudes Towards Petitions and Citizen Suits in Environmental Law and More Broadly}

Even where agencies (or Congress) have not developed specific petition processes, our analysis raises some questions about judicial treatment of petitions. As we noted earlier, courts have been tremendously deferential to agency denials of rulemaking petitions and to agency decisions about agenda-setting more broadly. Given our results, we wonder whether more aggressive judicial review of agency agenda-setting would necessarily result in fundamentally undermining the implementation of a statutory program. Reduced deference might be most warranted in conditions similar to those in this study-that is, where limited sets of relatively simple decisions require a relatively small universe of resource allocation trade-offs-although it is quite possible that our results call for reduced deference in a wider range of circumstances as well. ${ }^{217}$

Judicial attitudes towards petitions and citizen suits are likely to increase in importance in environmental law in the near future, because petitions and litigation over agency agenda-setting and inaction are themselves likely to increase. ${ }^{218}$ It has been many years since Congress has enacted a significant environmental statute that lays out new regulatory tasks for agencies, so as time passes, the initiative for updating environmental standards to keep pace with evolving technology, understanding of environmental harms, and changes in

implementing their regulatory programs. Cf. Stephenson, supra note 117, at 129-34 (noting that agencies may have incentives to encourage citizen suits to enforce regulatory programs).

217. Petitions, where an outside group directly interacts with an agency in an effort to shape the agency's agenda, do differ from litigation, where the outside group must work through the judicial process to shape the agency's agenda. In an adversarial system, litigation must be initiated by an outside group, and in general the only arguments that the court can consider are those made by the agency and outside groups. Thus, we believe our results still have some force for litigation as well. The question we cannot answer in this study is whether the interposition of courts between these two relatively expert parties would result in consistently sub-optimal outcomes. However, our study makes clear that courts' deference to agencies cannot be simply grounded on a suspicion of the expertise of the parties who bring litigation before the courts.

218. See Biber, Two Sides, supra note 39, at 500-03. 
public preferences has shifted to administrative agencies. ${ }^{219}$ As an example, consider that one of the main drivers of climate change policy in the United States is currently EPA's ongoing rulemaking about carbon dioxide emissions under the Clean Air Act-itself started by a petition, as noted in the Introduction. If our environmental policy agenda is increasingly being set in administrative agencies rather than in Congress, then the tools by which the public has a say in that agenda-setting (such as petitions or lawsuits over agency inaction) will also become increasingly important. Our results provide at least a moderately optimistic gloss on how useful those tools might be.

While environmental law is noted for the importance of technical analysis and expertise, it is certainly not unique in that way. A wide range of other areas within administrative law-ranging from airline and highway safety regulation to securities regulation-raise questions of technical expertise. Our results suggest that the broader use of petitions and citizen suits might help improve decisionmaking in these other areas as well. Likewise, our conclusions raise broader questions about judicial deference in administrative law, where courts often face agency decisions purportedly grounded in technical questions. Again, that deference implies an assumption that administrative agencies are more expert than outside interest groups that frequently challenge agency decisionmaking. ${ }^{220}$ That assumption has essentially been unstudied by scholars, ${ }^{221}$ and our results raise questions about whether it is warranted, particularly in situations where technical expertise depends on widely dispersed information. In those circumstances, agencies may not do better in performing their job if they are isolated from public participation and judicial review. Indeed, they may do worse.

Dispersed information might play an important role in a wide range of administrative processes, such as the detection of securities violations or even of unsafe consumer products. Indeed, even the critics of the petition process for the CPSC acknowledged its role in helping to bring important information to the agency about potentially dangerous products. ${ }^{222}$ The nuanced vision of agency expertise that our results provide is an important tonic for

219. Indeed, an entire symposium and special issue of a journal were recently dedicated to figuring out how to deal with the legislative "logjam." See Carol A. Casazza Herman et al., Breaking the Logjam: Environmental Reform for the New Congress and Administration, 17 N.Y.U. ENVTL. LJ. 1, 1-3, 15-16 (2008).

220. The same caveats apply about the role that courts might play as the interlocutors between outside groups and agencies in the course of judicial review. See supra note 217.

221. See Anne Joseph O'Connell, Political Cycles of Rulemaking: An Empinical Portrait of the Modern Administrative State, 94 VA. L. REV. 889, 981-83 (2008); see also Melnick, supra note 116, at 246 (calling for scholars to "provide us with detailed studies of cases in which the courts have improved policymaking").

222. See Schwartz, supra note 30, at 54 (noting the role that petitions have played in alerting CPSC to new risks). 
the arguments about judicial deference in administrative law. If expertise is not something that is necessarily exclusive to all government agencies in all contexts-such as areas involving dispersed knowledge-then we should at least question whether it can be a foundation for courts' across-the-board deference to agency decisionmaking, or whether it should instead be justified only in particular subject areas and particular situations, depending on the context. This is a far cry from the way that expertise has been relied upon in the academic literature and case law as a magic talisman that justifies judicial deference.

Harnessing the collective wisdom of the public has become a theme over the past few years in regulatory policy, but to this point it has only been a promise that is contingent on the deployment of the technology of the internet. ${ }^{223}$ Moreover, in the context of environmental law, the push for greater public participation is in tension with commentators who have emphasized the threat that public participation can pose to expertise. The ESA's listing program provides at least some tentative, initial evidence that the promise of drawing on the public to improve technical decisionmaking is not a mirage, and indeed does not necessarily depend on modern communications technology. We therefore provide some much-needed optimism about the possibility of reconciling the dichotomy of expertise and public participation in environmental law. Of course, it might be that our results are due to some unique features in endangered species management as compared to toxic substance risk management (the area most commonly cited for the dysfunctions of public participation $)^{224}$-though we are skeptical that the areas are so fundamentally different. In any case, our analysis highlights the need for more nuanced, more empirically based conclusions about how and why regulatory institutions work in environmental law.

223. See supra notes 14-15.

224. See, e.g., BREYER, supra note 91 , at ch. 1 . 


\section{APPENDIX: DETAILED METHODOLOGY}

Here we provide additional details about our methodology for the interested reader, focusing on: the FWS listing priority ranking score that we ultimately did not use in our analysis; important ambiguities and coding decisions for deciding whether species were the subject of a listing petition; the political control variables we used in our logistic regression; analysis of whether there was strategic manipulation of FWS's recovery priority scores; the time delay between the date of litigation initiation or petition submission and the assignment of the recovery priority score for a species; and the details of descriptive and diagnostic analyses that we conducted before proceeding with our logistic regression.

\section{A. Listing Priority Scores as an Alternative Measure of Species Characteristics}

As noted in Part I.B, FWS has two different priority systems to help allocate scarce resources in its decisionmaking process. FWS uses a listing priority score to determine which species should receive the highest priority for listing under the Act given limited resources. This score is an obvious first choice for our analysis since the information for this score is more contemporary to the date of litigation, petition submission, or ultimate listing decision than the recovery priority score. However, we ultimately could not use the listing priority in our full analysis.

FWS's listing priority is a twelve-point scale that considers three main factors: the seriousness of the threat of extinction faced by the species; the immediacy of the threat of extinction faced by the species; and how taxonomically unique the species is. ${ }^{225}$ Species that face more serious threats, more immediate threats, and that are more taxonomically unique receive higher listing priority rankings. In theory, more highly ranked species should be first in line to be listed.

The first problem with relying on the listing priority scores is that FWS only began publicly releasing those scores in a systematic way in 1997, in "candidate notices of review" (CNORs) published in the Federal Register. ${ }^{226}$

225. Endangered and Threatened Species Listing and Recovery Priority Guidelines, Notice, 48 Fed. Reg. 43,098 (Sept. 21, 1983).

226. Prior to 1997 , the listing priority rankings were not easily accessible to the public. See Lieben, supra note 123, at 1350 (noting that in settling litigation in 1997, FWS agreed to make "listing priority determinations for proposed species... available within a reasonable time to the general public upon request"). 
Thus, we do not have good listing priority data for species listed prior to 1997. Because of the limited time range, we had much less data to work with (only 144 species had a listing priority threat score, compared to 825 for the recovery priority rankings). For each species for which we did have listing priority scores, we used the listing priority score in the last CNOR published prior to the species's listing under the Act. As with recovery priority scores, we were able to disaggregate the "level of threat" score from the overall listing priority ranking. The level of threat score indicated whether a species either faced high or low threats.

However, the primary problem was the listing priority score data's underlying distribution. Of the 144 species for which we have threat level data from the listing priority rankings, 126 are in the high threat level, while only 18 are in the low threat level. This extremely skewed distribution is unsuitable for regression analysis. ${ }^{227}$ Nonetheless, the threat level data from the listing priority rankings and the threat level data from the recovery priority rankings are closely correlated, ${ }^{228}$ and we therefore doubt that our results in the logistic regression would be substantially different if we had been able to use the listing priority ranking threat level data for our full range of analyses.

We were able to do a limited analysis using simple descriptive statistics. Our comparison of the mean threat levels derived from the listing priority scores and the recovery priority scores showed one moderate difference: In the comparison between litigated and non-litigated species, there was a statistically significant difference between the threat levels derived from the recovery priority score but not between those derived from the listing priority score.

227. See D.R. COX \& D.V. HINKLEY, THEORETICAL STATISTICS 283-311 (1974) (noting that highly unbalanced dependent categorical variables are unsuitable for logistic regression where the number of observations is small).

228. A Pearson's product-moment correlation test found a significant correlation with a $p$-value of 0.008 
TABLE 6. Comparison of Threat Level Derived From

Recovery and Listing Priority Scores

\begin{tabular}{|c|c|c|c|c|}
\hline & Petition & No Petition & Litigation & $\begin{array}{c}\text { No } \\
\text { Litigation }\end{array}$ \\
\hline $\begin{array}{c}\text { Threat Level } \\
\text { (From Listing } \\
\text { Priority Ranking) }\end{array}$ & 1.12 & 1.13 & 1.13 & 1.11 \\
\hline $\begin{array}{c}\text { Threat Level } \\
\text { (From Recovery } \\
\text { Priority Ranking) }\end{array}$ & 1.28 & 1.33 & $1.27^{* *}$ & $1.37^{* *}$ \\
\hline
\end{tabular}

Values are mean subcomponent score for all species in the relevant category.

Threat Level (from Listing Priority Ranking): 1 = Highest Threat, $2=$ Lowest Threat

Threat Level (from Recovery Priority Ranking): 1 = Highest Threat,

$2=$ Medium Threat, $3=$ Lowest Threat

Difference between comparison is:

** = significant at 0.01 level

Based on Wilcoxon rank sum test.

\section{B. Coding for Petition Status}

There was one significant ambiguity in our coding for petition history. When Congress passed the ESA in 1973, it specifically authorized the Smithsonian to develop a list of plant species "which are now or may become endangered or threatened." ${ }^{229}$ The Smithsonian developed an initial list containing over 3000 species and submitted it to Congress and FWS. ${ }^{230}$ Both FWS and the Smithsonian also continued to provide updates for that list, including additions of new species over time. ${ }^{231}$ The majority of the plants currently listed under the ESA were initially identified through this process.

229. 16 U.S.C. $\$ 1541$ (2006).

230. See Threatened or Endangered Fauna or Flora, Notice, 40 Fed. Reg. 27,823, 27,824 (July 1, 1975).

231. See, e.g., Endangered and Threatened Wildlife and Plants: Findings of Certain Petitions and Reviews of Status for Several Species, 48 Fed. Reg. 6,752 (Feb. 15, 1983) (codified at 50 C.F.R. $\S 17$ (2010)); Endangered and Threatened Wildlife and Plants: Review of Plant Taxa for Listing as Endangered or Threatened Species, 45 Fed. Reg. 82,480 (Dec. 15, 1980) (codified at 50 C.F.R. $\$ 17$ (2010)); Endangered and Threatened Wildlife and Plants: Supplement to Review of Plant Taxa for Listing, 48 Fed. Reg. 53,640 (Nov. 28, 1983) (codified at 50 C.F.R. \$ 17 (2010)); Endangered and Threatened Wildlife and Plants: Notice of Review of Plant Taxa for Listing as Endangered or Threatened Species, 50 Fed. Reg. 39,526 (Sept. 27, 1985) (codified at 50 C.F.R. $\$ 17$ (2010)). 
Of the 745 flowering and non-flowering listed plant species, 554 were initially identified by the Smithsonian.

This process presents challenges for our analysis. On the one hand, these plant species were identified primarily by a group outside FWS, and FWS characterized these reports as petitions. ${ }^{232}$ On the other hand, to the extent that we are interested in comparing decisionmaking within government agencies versus decisionmaking from outside interest groups, the Smithsonian perhaps is better characterized as a government agency. While the Smithsonian does not do any regulation, it is a component of the federal government. ${ }^{233}$ Indeed, Congress apparently selected the Smithsonian to prepare the initial reports in 1973 in part because of its expertise in plant conservation compared to FWS at the time. ${ }^{234}$ We accordingly included the plant species identified in the Smithsonian reports or FWS updates as species that were not petitioned by outside groups.

We did check the impact of our decision on our analysis and ran our regressions described in Part 0 (Methodology) with the Smithsonian-reported species characterized as "petitioned" species. Our results did not change in any meaningful way.

\section{Political Control Variables}

We created control variables for politics based on both the executive branch and the legislative branch. With respect to the executive branch, we coded for the party of the president at the time of the listing of the species. ${ }^{235}$ With respect to the legislative branch, we included in our analysis a measure of the political power and relative friendliness to environmental protection in Congress at the time the species was listed: For each species, we determined whether there were any senators (1) representing states within the range of that

232. See Endangered and Threatened Wildlife and Plants: Review of Plant Taxa for Listing as Endangered or Threatened Species, 45 Fed. Reg. $82,480,82,480$ (Dec. 15, 1980) (codified at 50 C.F.R. $\S 17(2010))$.

233. See 20 U.S.C. $\$ \$ 41$ et seq. (2006).

234. See Rudy R. Lachenmeier, The Endangered Species Act of 1973: Preservation or Pandemomium?, 5 ENVTL. L. 29, 78 (1974) ("The fact that the Smithsonian playled] such a heady role emphasizes what [FWS] have already admitted: they know little if anything about what plants are threatened or endangered.").

235. We did not impose a time delay on the political coding (i.e., coding for the political situation six months prior to the listing of the species) for the president or Congress. While the listing of a species is a process that can take years, see infra notes 246-249 and accompanying text, listing decisions can be stopped very quickly by an unfriendly Administration. See, e.g., Harllee et al., supra note 153, at 30 (noting that President Reagan prevented the listing of any species under the ESA after his inauguration in 1981, with two species listed in January before that date). 
species, (2) serving on the two Senate subcommittees that have the most influence over endangered species policy, (3) during the year the species was listed. ${ }^{236}$ For those senators, we coded for attitudes towards environmental protection by using the League of Conservation Voters (LCV) score for the senator for the relevant Congress. ${ }^{237}$

Our hypotheses about the role that these political variables play is that, all other things being equal, senators with low LCV scores and Republican presidents would be less sympathetic to the listing of endangered species. Accordingly, we would expect that species listed under low LCV score senators and Republican presidents would have higher threat levels (because they are only listed when they are on the edge of extinction, rather than proactively), would be easier to recover (because there is a reluctance to spend large amounts of money on difficult-to-recover species), and would be less likely to pose conflicts with development projects.

Following is an overview of all of the independent variables (including the political variables) and predicted relationships between those independent variables and the three dependent variables.

236. The two subcommittees are the Interior Subcommittee of the Senate Appropriations Committee and the subcommittee of the Senate Environment and Public Works Committee with oversight authority over FWS. This latter committee varied by name over the years: Environmental Pollution (1986), Environmental Protection (1987-1992), Clean Water, Fisheries, and Wildlife (1993-94), Drinking Water, Fisheries, and Wildlife (1995-98), Fisheries, Wildlife, and Drinking Water (1999-2000), Fisheries, Wildlife, and Water (2001-2004).

Range data was obtained from David W. Cash et al., Database on the Economics and Management of Endangered Species, Economics Dep't, Harvard Univ. (Sept. 28, 1998) where available, and otherwise from NatureServe data. See infra note 243 for a description of NatureServe.

237. Cash et al., supra note 236. A number of species either were (a) not coded for range by Cash et al. and did not have range information in the NatureServe database, or (b) were not located within a jurisdiction that is represented in the Senate (e.g., Puerto Rico), and were accordingly not assigned range information. These species (which totaled sixty-nine) were excluded from our analysis.

We did not include information about the interaction between species range and the political landscape in the relevant House subcommittees with significant power over ESA implementation. The challenge is that we would need information about species' ranges at a level of detail finer than the state level (which is difficult to obtain for many species) in order to overlay them with the borders of House of Representative districts. While others have simply used species and House of Representative political information at the state level, see, e.g., Harllee et al., supra note 153, at 21 , given the significant biological and political heterogeneity within states such as California, Florida, and Texas, we feel that this is an extremely problematic approach. While it is true that the House is a major source of political influence, prior studies have found that the Senate is also relevant. See id. at 39. Because our goal is simply to control for political influence, rather than to provide a detailed assessment of how that political influence is being wielded, we use the Senate data alone. 
TABLE 7. Description of Independent Variables

\begin{tabular}{|l|l|}
\hline $\begin{array}{l}\text { Independent } \\
\text { Variables }\end{array}$ & $\begin{array}{l}\text { Was consideration of species for listing initiated by a citizen } \\
\text { petition? O=no, l=yes }\end{array}$ \\
\hline Petition & $\begin{array}{l}\text { Was the species the subject of litigation over listing? 0=no, } \\
\text { 1=yes }\end{array}$ \\
\hline Litigation & $\begin{array}{l}\text { Which taxonomic group is the species a member of? } \\
\text { Includes: Arachnid, Bird, Crustacean, Fish, Flowering Plant, } \\
\text { Insect, Mammal, Mussel, Non-flowering Plant, Reptile, } \\
\text { Snail }\end{array}$ \\
\hline $\begin{array}{l}\text { Presidential } \\
\text { Party }\end{array}$ & $\begin{array}{l}\text { Party of president at time of listing of species. 0=Democrat, } \\
\text { 1=Republican }\end{array}$ \\
\hline Interior LCV & $\begin{array}{l}\text { Average LCV scores of the senators who are (1) members } \\
\text { of the relevant Appropriations subcommittee that supervises } \\
\text { the Dep't of Interior (and FWS); and (2) represent states } \\
\text { that are within the range of the species at the time of the } \\
\text { listing of the species. Ranges from 0 to 100, with 100 being } \\
\text { the most conservation-friendly score issued by the LCV }\end{array}$ \\
\hline EPW LCV & $\begin{array}{l}\text { Average LCV scores of the senators who are (1) members } \\
\text { of the relevant Environment and Public Works subcom- } \\
\text { mittee that supervises the Dep't of Interior (and FWS); and } \\
\text { (2) represent states that are within the range of the spe- } \\
\text { cies at the time of the listing of the species. Ranges from 0 } \\
\text { to 100, with 100 being the most conservation-friendly score } \\
\text { issued by the LCV }\end{array}$ \\
\hline Year the species is listed \\
\hline Year Listed
\end{tabular}


TABLE 8. Expected Relationships Between Independent and Dependent Variables

\begin{tabular}{|c|c|c|c|}
\hline $\begin{array}{c}\text { Independent } \\
\text { Variables }\end{array}$ & Threat Level & $\begin{array}{l}\text { Recovery } \\
\text { Potential }\end{array}$ & Conflict \\
\hline Petition & \multirow{2}{*}{$\begin{array}{l}\text { Positive } \\
\text { (Agency has } \\
\text { expertise) }\end{array}$} & \multirow{2}{*}{$\begin{array}{l}\text { Positive } \\
\text { (Agency has } \\
\text { expertise) }\end{array}$} & \multirow{2}{*}{$\begin{array}{l}\text { Positive } \\
\text { (Agency has } \\
\text { expertise) }\end{array}$} \\
\hline Litigation & & & \\
\hline Presidential Party & $\begin{array}{l}\text { Negative } \\
\text { (Republicans } \\
\text { reluctant to } \\
\text { list species) }\end{array}$ & $\begin{array}{l}\text { Negative } \\
\text { (Republicans } \\
\text { reluctant to } \\
\text { list species) }\end{array}$ & $\begin{array}{l}\text { Negative } \\
\text { (Republicans } \\
\text { reluctant to } \\
\text { list species) }\end{array}$ \\
\hline Interior LCV & \multirow{2}{*}{$\begin{array}{c}\text { Positive } \\
\text { (Environmentally } \\
\text { friendly senators more } \\
\text { likely to } \\
\text { list species) }\end{array}$} & \multirow{2}{*}{$\begin{array}{l}\text { Positive } \\
\text { (Environmentally } \\
\text { friendly senators } \\
\text { more likely to list } \\
\text { species) } \\
\end{array}$} & \multirow{2}{*}{$\begin{array}{c}\text { Positive } \\
\text { (Environmentally } \\
\text { friendly senators } \\
\text { more likely to } \\
\text { list species) } \\
\end{array}$} \\
\hline EPW LCV & & & \\
\hline Year Listed & $\begin{array}{l}\text { Negative } \\
\text { (Species become } \\
\text { harder to list } \\
\text { over time) }\end{array}$ & $\begin{array}{l}\text { Negative } \\
\text { (Species become } \\
\text { harder to list } \\
\text { over time) }\end{array}$ & $\begin{array}{l}\text { Negative } \\
\text { (Species become } \\
\text { harder to list } \\
\text { over time) }\end{array}$ \\
\hline \multicolumn{4}{|l|}{ Taxonomic Group } \\
\hline Arachnid & $\begin{array}{c}\text { Negative } \\
\text { (Agency reluctant to } \\
\text { list uncharismatic } \\
\text { species) }\end{array}$ & $\begin{array}{c}\text { Negative } \\
\text { (Agency reluctant to } \\
\text { list uncharismatic } \\
\text { species) }\end{array}$ & $\begin{array}{c}\text { Negative } \\
\text { (Agency reluctant } \\
\text { to list uncharismatic } \\
\text { species) } \\
\end{array}$ \\
\hline Bird & $\begin{array}{c}\text { Positive } \\
\text { (Agency eager to list } \\
\text { charismatic species) }\end{array}$ & $\begin{array}{c}\text { Positive } \\
\text { (Agency eager to list } \\
\text { charismatic species) }\end{array}$ & $\begin{array}{c}\text { Positive } \\
\text { (Agency eager to list } \\
\text { charismatic species) }\end{array}$ \\
\hline Crustacean & \multirow{4}{*}{$\begin{array}{c}\text { Negative } \\
\text { (Agency reluctant to } \\
\text { list uncharismatic } \\
\text { species) }\end{array}$} & \multirow{4}{*}{$\begin{array}{c}\text { Negative } \\
\text { (Agency reluctant to } \\
\text { list uncharismatic } \\
\text { species) }\end{array}$} & \multirow{4}{*}{$\begin{array}{c}\text { Negative } \\
\text { (Agency reluctant } \\
\text { to list uncharismatic } \\
\text { species) }\end{array}$} \\
\hline Fish & & & \\
\hline Flowering Plant & & & \\
\hline Insect & & & \\
\hline Mammal & $\begin{array}{c}\text { Positive } \\
\text { (Agency eager to list } \\
\text { charismatic species) }\end{array}$ & $\begin{array}{c}\text { Positive } \\
\text { (Agency eager to list } \\
\text { charismatic species) }\end{array}$ & $\begin{array}{c}\text { Positive } \\
\text { (Agency eager to list } \\
\text { charismatic species) }\end{array}$ \\
\hline Mussel & \multirow{4}{*}{$\begin{array}{c}\text { Negative } \\
\text { (Agency reluctant to } \\
\text { list uncharismatic } \\
\text { species) }\end{array}$} & \multirow{4}{*}{$\begin{array}{c}\text { Negative } \\
\text { (Agency reluctant to } \\
\text { list uncharismatic } \\
\text { species) }\end{array}$} & \multirow{4}{*}{$\begin{array}{c}\text { Negative } \\
\text { (Agency reluctant } \\
\text { to list uncharismatic } \\
\text { species) }\end{array}$} \\
\hline $\begin{array}{l}\text { Non-flowering } \\
\text { Plant }\end{array}$ & & & \\
\hline Reptile & & & \\
\hline Snail & & & \\
\hline
\end{tabular}

Threat Level (from Listing Priority Ranking): 1 = Highest Threat, $2=$ Lowest Threat

Threat Level (from Recovery Priority Ranking): 1 = Highest Threat,

$2=$ Medium Threat, $3=$ Lowest Threat

Recovery Potential: $1=$ High, 2 = Low 


\section{Tests for Strategic Manipulation}

We wanted to ensure that FWS was not strategically manipulating its recovery priority ranking system to make its own performance appear better. ${ }^{238}$ For instance, FWS might be purposefully giving lower recovery priority scores to the species listed because of petitions or litigation in order to make its decisions to list species on its own initiative look relatively better. There has been some speculation that FWS has manipulated its own status trend evaluations of listed species (that is, its evaluations of whether species on the ESA list are improving, stable, or declining, which it is required to report every two years to Congress $)^{239}$ in order to make its performance under the ESA look better. ${ }^{240}$

We are skeptical that FWS is actively manipulating the recovery priority ranking system in this way. Until our analysis, this data has, to our knowledge, never been considered before by anyone. Moreover, the recovery priority rankings have little regulatory impact-they are only supposed to guide the agency's own internal allocation of resources within the recovery program. And the evidence available indicates that they in fact have very little impact on the allocation of those resources. ${ }^{241}$ Thus, we have little reason to believe that the agency has other reasons to strategically skew these evaluations.

238. The listing and recovery priority ranking systems are likely based on an expert guess within the agency, similar to other evaluations of species status by the agency. See P. Dee Boersma et al., How Good Are Endangered Species Recovery Plans?, 51 BioSCIENCE 643, 645 (2001); Male \& Bean, supra note 143 , at 990 .

239. See 16 U.S.C. $\$ 1533(\mathrm{f})(3)$ (2006).

240. See Ferraro et al., supra note 153, at 247.

241. See, e.g., Deborah Dawson \& Jason F. Shogren, An Update on Priorities and Expenditures Under the Endangered Species Act, 77 LAND ECON. 527 (2001); Male \& Bean, supra note 143, at 990; Restani \& Marzluff, supra note 73, at 169; Marco Restani \& John M. Marzluff, Avian Conservation Under the Endangered Species Act: Expenditures Versus Recovery Priorities, 15 CONSERVATION BIOLOGY 1292, 1292 (2001) [hereinafter Restani \& Marzluff, Avian Conservation]. But see Andrew Metrick \& Martin L. Weitzman, Conflicts and Choices in Biodiversity Preservation, 12 J. ECON. PERSP. 21, 31-32 (1998) (finding that priority scores have some impact on spending levels, although not as much as expected); U.S. GOV'T ACCOUNTABILITY OFFICE, GAO-05-211, ENDANGERED SPECIES-FISH AND WILDLIFE SERVICE GENERALLY FOCUSES RECOVERY FundING ON HIGH-PRIORITY SPECIES, BUT NEEDS TO PERIODICALLY ASSESS ITS FUNDING DECISIONS 30 (2005) (finding that priority scores generally correlate with spending levels, but more by accident than because of purposeful allocation of funds by agency). This may well be because many funding decisions for species are made by Congress through the appropriations process rather than by the agency. See DeShazo \& Freeman, supra note 153, at 1476-77, 1480, 1484-86; Restani \& Marzluff, Avian Conservation, supra, at 1292, 1298. Recovery priority rankings apparently also have little to do with other major management decisions under the ESA. See Jonathan M. Hoekstra, William F. Fagan \& Jeffrey E. Bradley, A Critical Role for Critical Habitat in the Recovery Planning Process? Not Yet, 12 ECOLOGICAL APPLICATIONS 701, 703 (2002) (finding no statistically significant relationship between the designation of critical habitat for listed species and the recovery priority score for the species); Carolyn J. Lundquist et al., Factors Affecting Implementation 
Nonetheless, to ensure that there was no strategic manipulation, we compared the threat level component of the recovery priority rankings for all species in the 2004 Recovery Report with an outside estimate of threat level for those species. ${ }^{242}$ We used data from the NatureServe database, which provides status evaluations of many species in North America. ${ }^{243}$ Our hypothesis was that if there was no significant strategic manipulation of the FWS recovery priority scores, then the threat level determinations for the FWS recovery priority scores would not vary much from the status evaluations of NatureServe. We found a strongly significant correlation between the NatureServe status evaluations and the FWS 2004 threat level rankings, ${ }^{244}$ indicating that there is not substantial (if any) strategic manipulation by FWS. ${ }^{245}$

We were unable to conduct a similar test for strategic manipulation for the recovery potential and conflict FWS rankings. However, given the relative lack of importance of the FWS recovery priority system (as noted above) and the lack of any evidence of manipulation of the degree of threat rankings (which are the most important for determining a species's placement in the recovery priority system), we think it highly unlikely that any strategic manipulation is occurring for these factors either.

of Recovery Plans, 12 ECOLOGICAL APPLICATIONS 713, 717 (2002) (finding no connection between recovery priority scores and implementation of plans for the recovery of listed species).

242. For this analysis we included all species listed in the 2004 Recovery Report.

243. NatureServe is a national nonprofit conservation organization that provides a central repository about the status of rare and endangered species. It is a network of "natural heritage" programs across North America. Those programs are a mix of nongovernmental and governmental agencies. See About Us, NATURESERVE, http://www.natureserve.org/aboutUs/index.jsp (last visited Nov. 10, 2010). The NatureServe database provided status information for 1096 of the 1251 species listed in the 2004 Recovery Report.

244. We conducted a Spearman's rank correlation test. The correlation is significant to a $p$-value of $3 * 10-15$, and tho equals 0.27 . Species that were rated by NatureServe as facing a greater risk of extinction were more likely to be also rated by FWS as facing a higher threat level than would be expected from a random distribution. See supra tbl.5.

245. Our results are consistent with David N. Laband \& Michael Nieswiadomy, Factors Affecting Species' Risk of Extinction: An Empirical Analysis of ESA and NanureServe Listings, 24 CONTEMP. ECON. POL'Y $160,160,170$ (2006). 
TABLE 9. Comparison of the Distribution of Species by NatureServe N-Values and FWS Threat Levels From the 2004 Recovery Report

\begin{tabular}{|c|c|c|c|}
\cline { 2 - 4 } \multicolumn{1}{c|}{} & \multicolumn{3}{c|}{ FWS Threat Levels 2004 Recovery Report } \\
\hline $\begin{array}{c}2008 \\
\text { NatureServe } \\
\text { N-Values }\end{array}$ & 1 & 2 & 3 \\
\hline 0 & 27 & 1 & 1 \\
\hline 0.5 & 1 & 0 & 0 \\
\hline 1 & 568 & 159 & 13 \\
\hline 1.5 & 9 & 4 & 0 \\
\hline 2 & 122 & 95 & 23 \\
\hline 2.5 & 4 & 4 & 0 \\
\hline 3 & 30 & 27 & 6 \\
\hline 4 & 1 & 0 & 1 \\
\hline
\end{tabular}

Spearman's rank correlation test, correlation is significant to p-value of $3 * 10^{-15}$, and rho equals 0.27 .

For both NatureServe N-Values and FWS Threat Levels, species that have a lower rating are at greater risk of endangerment.

E. Time Delay Between the Date of Petition/Litigation and Date of Assignment of Recovery Priority Score

There is necessarily a time delay between the initial date of the filing of a petition or a lawsuit by the outside group and the date of the listing of the species and its subsequent rating on FWS's recovery priority system. During that time frame, significant changes might occur with respect to the speciesmost importantly, its status might decline (as it is without ESA protection) and therefore the threat level might be higher. As a result, the status of species at the time they receive their priority system rating might be consistently worse than their status at the time when they were the subject of a petition or a lawsuit.

To the extent that we are trying to assess the ability of outside groups to identify the status of species at the time of the petition or litigation, then this delay might be an issue. ${ }^{246}$ However, in order for this to systematically alter our conclusions, species that are the subject of petitions or lawsuits must be waiting for protection significantly longer than species that are considered for listing by the agency on its own initiative. In other words, even if species see a continued decline between the date of the filing of a petition or lawsuit

246. See supra note 143 for more discussion. 
and the date of listing, that decline must be more than the similar decline that necessarily occurs between the date that FWS first considers listing a species on its own initiative and the date when FWS lists that species. Assuming that all species have a (more or less) similar rate of decline in status over time, there would be an issue for our analysis only if there is a longer gap between the date of petition or litigation activity and eventual listing than there is between the date of FWS sua sponte consideration of a species and eventual listing for species that are not the subject of petitions or litigation.

A preliminary analysis shows that the time frame between initial consideration by FWS and final listing is somewhat longer than the time frame between an initial petition and final listing. ${ }^{247}$ Our analysis is consistent with another study that found that, for species for which the listing process was initiated after 1982, those species that were initially identified by a petition took less time to be listed than agency-initiated species. ${ }^{248}$ That same study also found that listed species that were the subject of litigation generally took much less time to be listed than listed species that were not the subject of litigation. ${ }^{249}$ Thus, any bias in our analysis should cut against finding expertise for outside groups and bias the results in favor of the agency.

\section{F. Description of Statistical Analysis and Diagnostic Tests}

All analyses were performed on the statistical package $\mathrm{R}^{250}$ except for our bootstrapping reanalysis. Our core analysis used ordinal or standard logistic regression because all of our dependent variables were non-continuous and either binary or ordinal with a very limited range. Before we constructed our model, we conducted descriptive statistical analysis on both dependent and independent variables and analyzed whether any correlations between our variables would interfere with the basic assumptions of our statistical tests.

The subcomponents of the recovery priority score that we are interested in (threat level, recovery potential, and presence or absence of conflict) and that

247. The mean number of years between petition date and date of listing is 5.66 , while the mean number of years between initial consideration by FWS (usually by listing as a candidate species) and date of listing is 6.79 . We use final listing here as a proxy for the date FWS provided a recovery priority ranking, but the overall result should not be significantly different. (Date of listing data was taken from the CBD database, limited to species in our analysis. We excluded species that were identified by the Smithsonian reports in the 1970s, as discussed supra notes 229-234 and accompanying text.).

248. See Greenwald et al., supra note 48 , at 63 (finding that petition species took 4.3 years to list compared to 5.0 years for agency-initiated species).

249. See id. at 63 (finding that litigated species took only 2.4 years for issuance of a proposed rule, compared to 7.1 years for species without litigation, and that species took 1.4 years to be listed after a proposed rule without litigation but only 0.7 years to be listed after a proposed rule with litigation).

250. R-PROJECT, http://www.R-project.org (last visited Nov. 10, 2010). 
we are using as dependent variables did not show any distributions or skews that would make analysis using standard regression techniques inappropriate.

TABLE 10. Distributions of Dependent Variables Used in the Model

\begin{tabular}{|c|c|c|c|c|}
\hline & \multicolumn{4}{|c|}{ Variable Value } \\
\hline Variable & 0 & 1 & 2 & 3 \\
\hline $\begin{array}{c}\text { Threat Level } \\
\text { (Recovery Priority } \\
\text { Ranking) }\end{array}$ & - & 586 & 213 & 25 \\
\hline Recovery Potential & - & 508 & 316 & - \\
\hline Conflict & 644 & 180 & - & - \\
\hline
\end{tabular}

With respect to the independent variables, we found a sufficiently balanced distribution of our two most important variables (petition status and litigation status) to support using logistic regression (Table 11). We did not find a strong correlation between petition status and litigation status, nor did we find any other distribution or correlation concerns with the other independent variables. ${ }^{251}$ However, in undertaking our exploratory analysis, we did discover two important correlations connected to the year that a species was listed. This variable showed a significant positive correlation with both the probability that a species would be litigated and a significant negative correlation with the threat level for the species. ${ }^{252}$

251. See infra tbl.12. We did find substantial variations in the level of petition and litigation activity by taxonomic group, but there was no consistent pattern in those levels across taxonomic groups. In other words, we did not find that "higher-level" taxonomic groups (e.g., mammals and birds) consistently had higher or lower levels of petition or litigation activity than "lower-level" taxonomic groups (for example, plants, insects, mussels). See infra tbl.13.

252. We did not find a correlation between the year a species was listed and the likelihood that a species was the subject of a petition that was significant below the $p=0.05$ level. 
TABLE 11. Distributions of Independent Variables

\begin{tabular}{|l|c|c|}
\hline & Variable Value & \\
\hline Variable & 0 & 1 \\
\hline Petition & 726 & 98 \\
\hline Litigation & 390 & 434 \\
\hline
\end{tabular}

$\mathrm{N}=824$

TABLE 12. Correlations Among Non-Taxonomic Independent Variables

\begin{tabular}{|l|l|r|r|r|r|l|}
\hline & & Petition & Litigation & $\begin{array}{c}\text { Year } \\
\text { Listed }\end{array}$ & $\begin{array}{c}\text { Interior } \\
\text { LCV }\end{array}$ & $\begin{array}{c}\text { EPW } \\
\text { LCV }\end{array}$ \\
\hline Litigation & Correlation & 0.0499 & & & & \\
\hline & $p$-value & 0.1522 & & & & \\
\hline Year Listed & Correlation & 0.06505 & 0.5500 & & & \\
\hline & $p$-value & 0.0620 & $<0.0001$ & & & \\
\hline $\begin{array}{l}\text { Interior } \\
\text { LCV }\end{array}$ & Correlation & -0.0251 & 0.3113 & 0.398 & & \\
\hline & p-value & 0.4712 & $<0.0001$ & $<0.0001$ & & \\
\hline EPW LCV & Correlation & -0.1169 & 0.0500 & -0.0095 & 0.2013 & \\
\hline & $p$-value & $<0.001$ & 0.1544 & 0.7854 & $<0.0001$ & \\
\hline $\begin{array}{l}\text { Presidential } \\
\text { Party }\end{array}$ & Correlation & 0.0382 & -0.3632 & -0.7490 & -0.2791 & -0.0123 \\
\hline & $p$-value & 0.2734 & $<0.0001$ & $<0.0001$ & $<0.0001$ & $<0.0001$ \\
\hline
\end{tabular}

Analysis done with Spearman rank-correlation. $\mathrm{N}=824$. 
TABLE 13. Distribution of Petition and Litigation Activity by Taxonomic Group

\begin{tabular}{|l|l|c|}
\hline Taxon & & $\begin{array}{c}\text { Proportion of Species } \\
\text { Litigated or Petitioned }\end{array}$ \\
\hline \multirow{2}{*}{ Amphibian } & Litigation & 0.78 \\
& Petition & 0.78 \\
\hline \multirow{2}{*}{ Arachnid } & Litigation & 0.58 \\
& Petition & 0.75 \\
\hline \multirow{2}{*}{ Bird } & Litigation & 0.65 \\
& Petition & 0.30 \\
\hline \multirow{2}{*}{ Crustacean } & Litigation & 0.47 \\
& Petition & 0.65 \\
\hline \multirow{2}{*}{ Fish } & Litigation & 0.21 \\
& Petition & 0.40 \\
\hline \multirow{2}{*}{ Flowering Plant } & Litigation & 0.61 \\
& Petition & 0.07 \\
\hline \multirow{2}{*}{ Insect } & Litigation & 0.42 \\
& Petition & 0.68 \\
\hline \multirow{2}{*}{ Mammal } & Litigation & 0.46 \\
& Petition & 0.39 \\
\hline \multirow{2}{*}{ Mussel } & Litigation & 0.02 \\
& Petition & 0.00 \\
\hline \multirow{2}{*}{ Non-Flowering Plant } & Litigation & 0.66 \\
& Petition & 0.03 \\
\hline \multirow{2}{*}{ Reptile } & Litigation & 0.29 \\
& Petition & 0.36 \\
\hline \multirow{2}{*}{ Snail } & Litigation & 0.42 \\
& Petition & 0.29 \\
\hline Total Average of Litigation & 0.53 \\
\hline Total Average of Petition & 0.12 \\
\hline \multirow{2}{*}{ No: Van } & & \\
\hline
\end{tabular}

Note: Values are average amounts for all species within taxonomic group. 
FIGURE 1. Change in Proportion of Species Litigated as a Function of the Date Species Was Listed

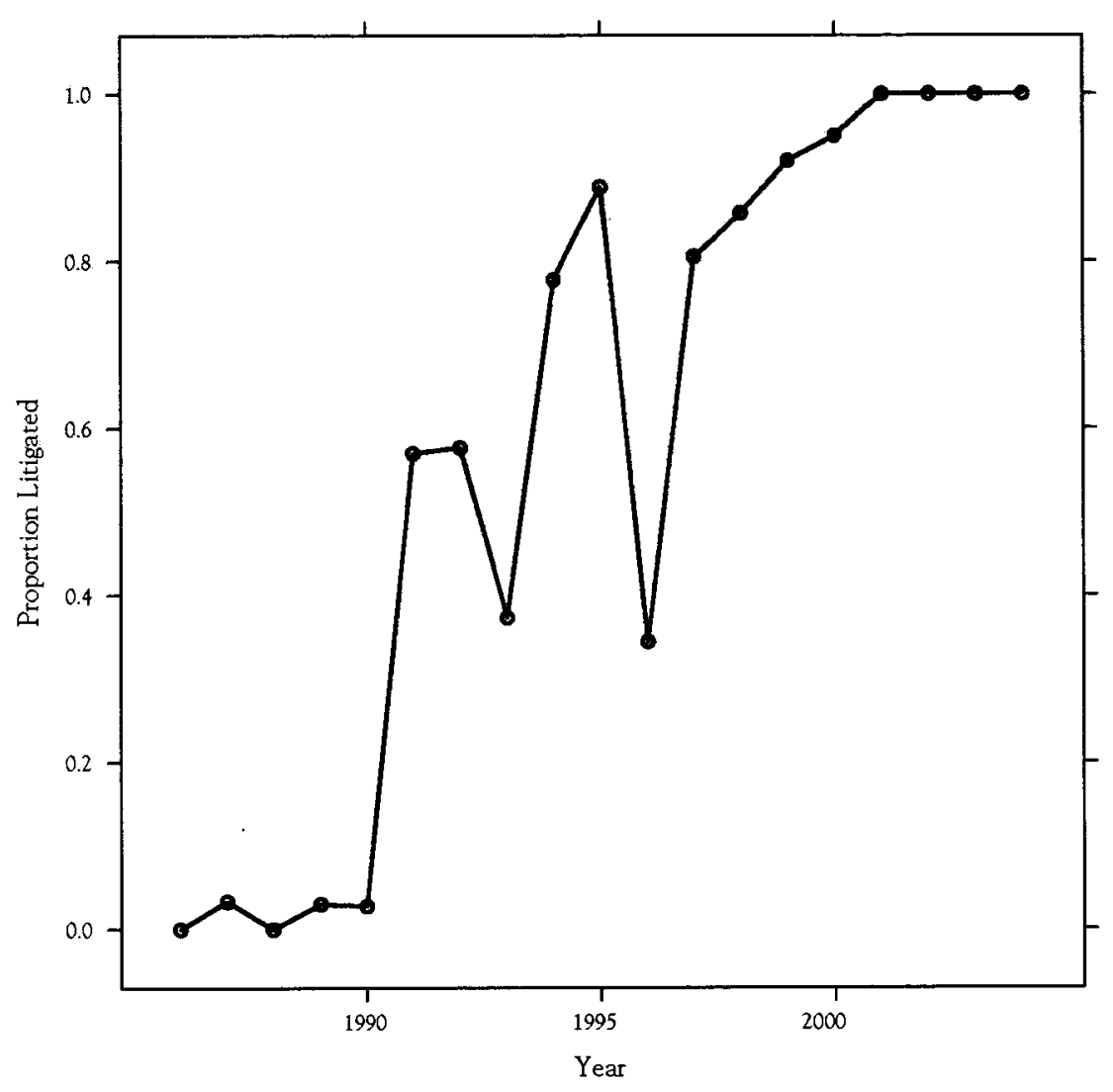


FigURE 2. Average Threat Level of Species Listed Over Time (Based on Recovery Priority Ranking).

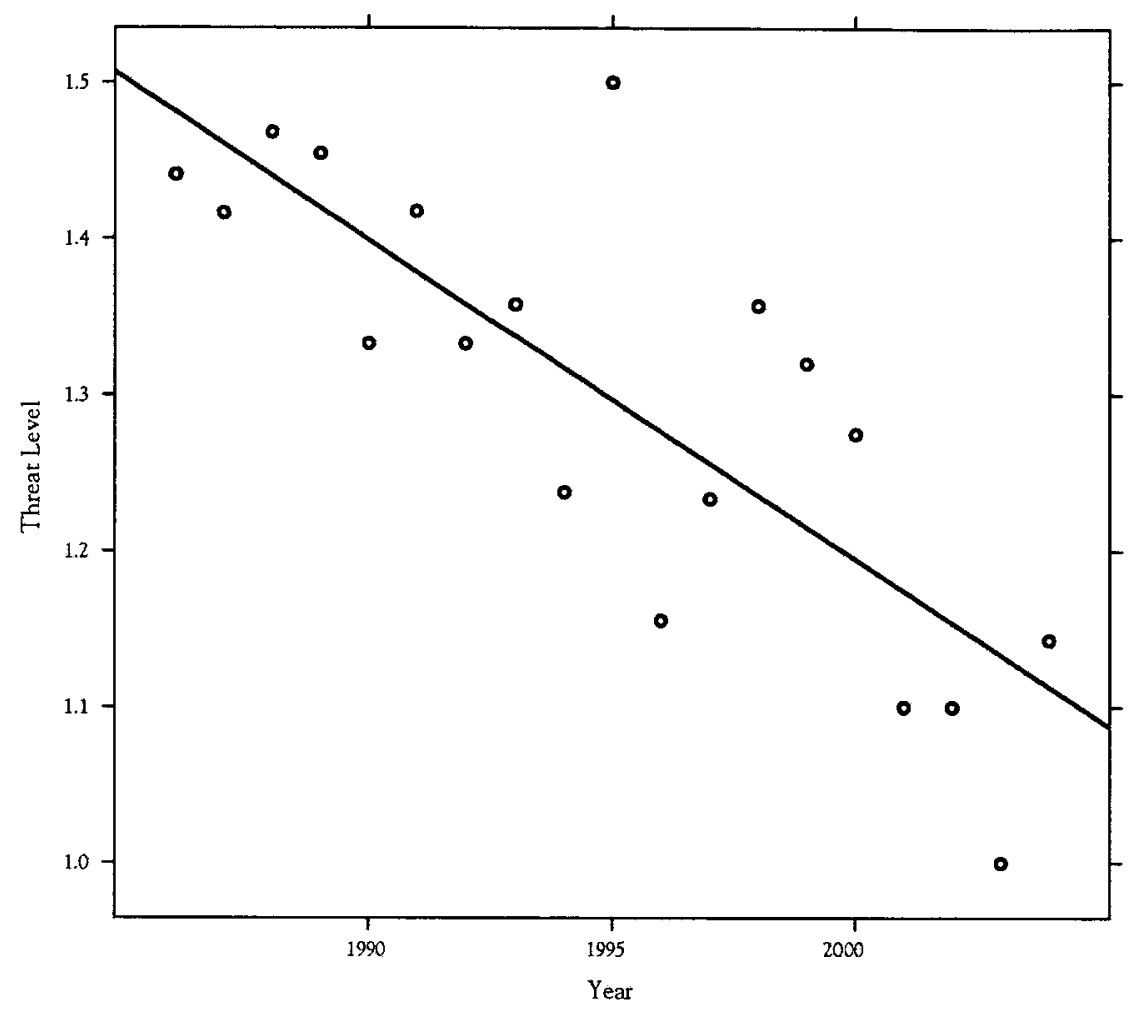

